\title{
Ddpd as Expanded Terpyridine: Dramatic Effects of Symmetry and Electronic Properties in First Row Transition Metal Complexes
}

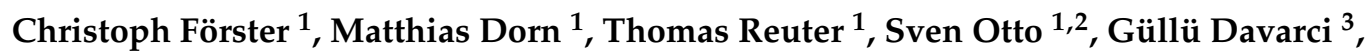 \\ Tobias Reich $^{3}$ (D), Luca Carrella ${ }^{1}$, Eva Rentschler ${ }^{1}$ and Katja Heinze ${ }^{1, *}$ (D) \\ 1 Institute of Inorganic Chemistry and Analytical Chemistry, Johannes Gutenberg University of Mainz, \\ Duesbergweg 10-14, 55128 Mainz, Germany; cfoerster@uni-mainz.de (C.F.); \\ matthiasdorn@uni-mainz.de (M.D.); t.reuter@uni-mainz.de (T.R.); sven.otto@uni-mainz.de (S.O.); \\ carrella@uni-mainz.de (L.C.); rentschl@uni-mainz.de (E.R.) \\ 2 Graduate School Materials Science in Mainz, Staudingerweg 9, 55128 Mainz, Germany \\ 3 Institute of Nuclear Chemistry, Fritz-Strassmann-Weg 2, 55128 Mainz, Germany; \\ davarci@students.uni-mainz.de (G.D.); treich@uni-mainz.de (T.R.) \\ * Correspondence: katja.heinze@uni-mainz.de; Tel.: +49-6131-39-27277
}

Received: 26 July 2018; Accepted: 22 August 2018; Published: 27 August 2018

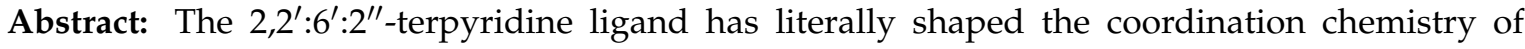
transition metal complexes in a plethora of fields. Expansion of the ligand bite by amine functionalities between the pyridine units in the tridentate $N, N^{\prime}$-dimethyl- $N, N^{\prime}$-dipyridine-2-ylpyridine-2,6-diamine ligand (ddpd) modifies the properties of corresponding transition metal complexes, comprising redox chemistry, molecular dynamics, magnetism and luminescence. The origins of these differences between ddpd and tpy complexes will be elucidated and comprehensively summarized with respect to first row transition metal complexes with $\mathrm{d}^{2}-\mathrm{d}^{10}$ electron configurations. Emerging applications of these ddpd complexes complementary to those of the well-known terpyridine ligand will be highlighted.
\end{abstract}

Keywords: tridentate ligands; expanded terpyridine; pincer ligands; ligand bite angle; ligand field splitting; 3d metal ions

\section{Introduction}

Pincer-type $[1,2]$ terpyridine ligands $\left(2,2^{\prime}: 6^{\prime}, 2^{\prime \prime}\right.$-terpyridine tpy; pincer ligands are tridentate, 6 -electron donor ligands that enforce a meridional coordination geometry on the metal centre) and their manifold complexes [3] play a central role in key fields of coordination chemistry with important applications in supramolecular chemistry [4-14], spin-crossover (SCO) phenomena [15-18], homogeneous catalysis [19-21], biomedical applications [22], redox non-innocence [23-27] or photochemistry $[6,7,28]$, to name just a few.

Variations of the prototypical tpy ligand include substitution at the central and outer pyridines, ring annulation at the outer $\mathrm{N}$-heterocycles, for example, forming quinolines and substitution of pyridines by other heterocycles such as thiophenes or pyrimidines. Expansion of the tpy scaffold by formally inserting a single-atom bridge between the pyridines has been very successfully employed especially in the field of emissive ruthenium(II) complexes and photosensitizers [28-38].

The effect of tpy ligand expansion in other, especially $3 \mathrm{~d}$ metal complexes has been only scarcely explored and a systematic description and comparison with the prototypical tpy complexes is lacking. This review summarizes all available data on the expanded ligand ddpd ( $N, N^{\prime}$-dimethyl- $N, N^{\prime}$-dipyridine-2-yl-pyridine-2,6-diamine), its homoleptic metal complexes 
$\left[\mathrm{M}(\mathrm{ddpd})_{2}\right]^{n+}$ covering $\mathrm{d}^{2}-\mathrm{d}^{10}$ electron configurations of the metal centre and a few heteroleptic complexes $\mathrm{MCl}_{n}(\mathrm{ddpd})$ and $[\mathrm{M}(\mathrm{dcpp})(\mathrm{ddpd})]^{2+}$ (dcpp = 2,6-bis(2-carbonylpyridyl)pyridine). A special focus will be placed on the similarities and differences with respect to analogous terpyridine complexes (Scheme 1) in the fields of stereochemical, dynamic, magnetic, redox and photophysical phenomena.
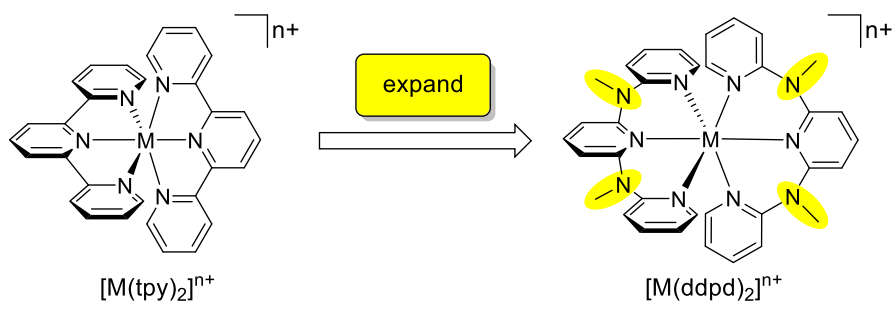

Scheme 1. Homoleptic metal complexes of the tridentate polypyridine ligands tpy and ddpd.

\section{Properties of the Ligand ddpd}

The famous tridentate ligand tpy and its derivatives are typically prepared via copper or palladium mediated C-C coupling reactions or via Kröhnke condensation reactions $[28,39,40]$. The related expanded terpyridine ligand ddpd and its derivatives (deuterated, $\mathrm{N}$-protonated, $\mathrm{N}$-alkylated) can be prepared by three different routes [35,41,42]. The most direct and convenient way to ddpd is by nucleophilic substitution of 2,6-dibromopyridine with deprotonated 2-(methylamino)pyridine (Scheme 2a) [35]. The inverse substitution of 2-bromopyridine with deprotonated 2,6-diaminopyridine first yields the ligand 2,6 bis(2-pyridylamino)pyridine $\left(\mathrm{H}_{2} \mathrm{tpda}\right)$ [41]. This parent ligand is then $N$-alkylated by alkyl iodides such as methyl iodide to give ddpd, $n$-propyl iodide or $n$-hexyl iodide to give $\mathrm{R}_{2}$ tpda $\left(\mathrm{R}={ }^{\mathrm{n}} \mathrm{Pr},{ }^{\mathrm{n}} \mathrm{Hex}\right.$; Scheme $2 \mathrm{~b}$ ) [43]. For deuterated derivatives of ddpd, starting from [D $\mathrm{D}_{5}$-pyridine via its [ $\left.\mathrm{D}_{5}\right]-\mathrm{N}$-oxide and coupling with 2,6-diaminopyridine proved to be convenient to yield $\left[\mathrm{D}_{8}\right]-\mathrm{H}_{2}$ tpda. Alkylating $\left[\mathrm{D}_{8}\right]-\mathrm{H}_{2}$ tpda with $\mathrm{CD}_{3}$ I gives the deuterated ligand $\left[\mathrm{D}_{14}\right]$-ddpd (Scheme 2c) [42].

a)<smiles></smiles>

b)<smiles>Brc1ccccn1</smiles>
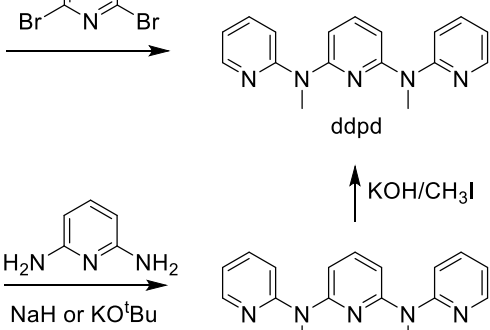

c)<smiles>C1=C[R]2=CC=C(c3ccco3)C2=C1</smiles>

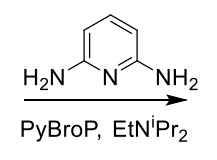<smiles>c1ccc(Nc2cccc(Nc3ccccn3)n2)nc1</smiles><smiles>[R]N(c1ccccn1)c1cccc(N([R])[R16]([R16])([H])[H])n1</smiles>

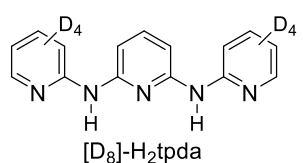
$\left(\mathrm{R}={ }^{\mathrm{n}} \mathrm{Pr},{ }^{\mathrm{n}} \mathrm{Hex}\right)$

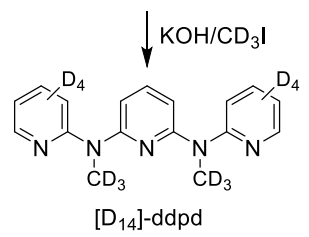

Scheme 2. Syntheses of (a) ddpd, (b) $\mathrm{H}_{2}$ tpda, $\mathrm{R}_{2}$ tpda ( $\left.\mathrm{R}={ }^{\mathrm{n}} \mathrm{Pr},{ }^{\mathrm{n}} \mathrm{Hex}\right)$ and (c) $\left[\mathrm{D}_{8}\right]-\mathrm{H}_{2}$ tpda and $\left[\mathrm{D}_{14}\right]$-ddpd; KHMDS = potassium bis(trimethylsilyl)amide, $m$-CPBA = meta-chloroperoxybenzoic acid, PyBroP = bromotripyrrolidinophosphonium hexafluorophosphate [35,41-43]. 
Similar to tpy [44], ddpd is not pre-organized for metal complexation and the terminal pyridines are oriented outward (Figure 1a,c). This allows for $\mathrm{CH} \cdots \mathrm{N}$ hydrogen bonding interactions and avoids repulsion between the pyridine nitrogen lone pairs and between $\mathrm{CH}$ groups (Figure 1a). Terpyridine forms 5-membered rings including a $\mathrm{CH}^{\cdots} \mathrm{N}$ hydrogen bond with the central pyridine nitrogen atom N2 (Figure 1c), while the additional N-Me groups in ddpd enforce 6-membered rings with N2 (Figure 1a).

Although the N-Me group of ddpd should be more basic [45,46], addition of acid protonates one terminal pyridine unit (N1) and both terminal pyridines rearrange to point inward allowing for one short and one medium long N1H1 $\cdots \mathrm{N} 2 / \mathrm{N} 3$ hydrogen bond with $\mathrm{N} \cdots \mathrm{N}$ distances in the cavity of 2.51, 2.81 and $3.24 \AA$ (Figure 1b). This hydrogen bonding pattern favours the observed pyridine protonation site similar to pre-organized proton sponges with $\mathrm{N} \cdots \mathrm{N}$ distances between 2.3 and $2.6 \AA$ [47]. The cavity formed by the three pyridines is somewhat too large for the small proton resulting in two different distorted six-membered chelate rings (Figure 1b). On the other hand, this cavity should perfectly fit to accommodate metal ions. Tpy is protonated at N1 as well (Figure 1d) [48]. However, tpy only realizes a single N1H1 $\cdots$ N2 hydrogen bond with an N1 $\cdots \mathrm{N} 2$ distance of $2.65 \AA$ forming a five-membered ring, while the second pyridine (N3) remains oriented outward. The $\left[\mathrm{CF}_{3} \mathrm{SO}_{3}\right]^{-}$counterion additionally binds to the pyridinium site N1H1.

The conformations and protonation sites already point to key differences between tpy and ddpd, namely the different available ring sizes and the proton sponge-like behaviour of ddpd due to its electron-richness and flexibility.
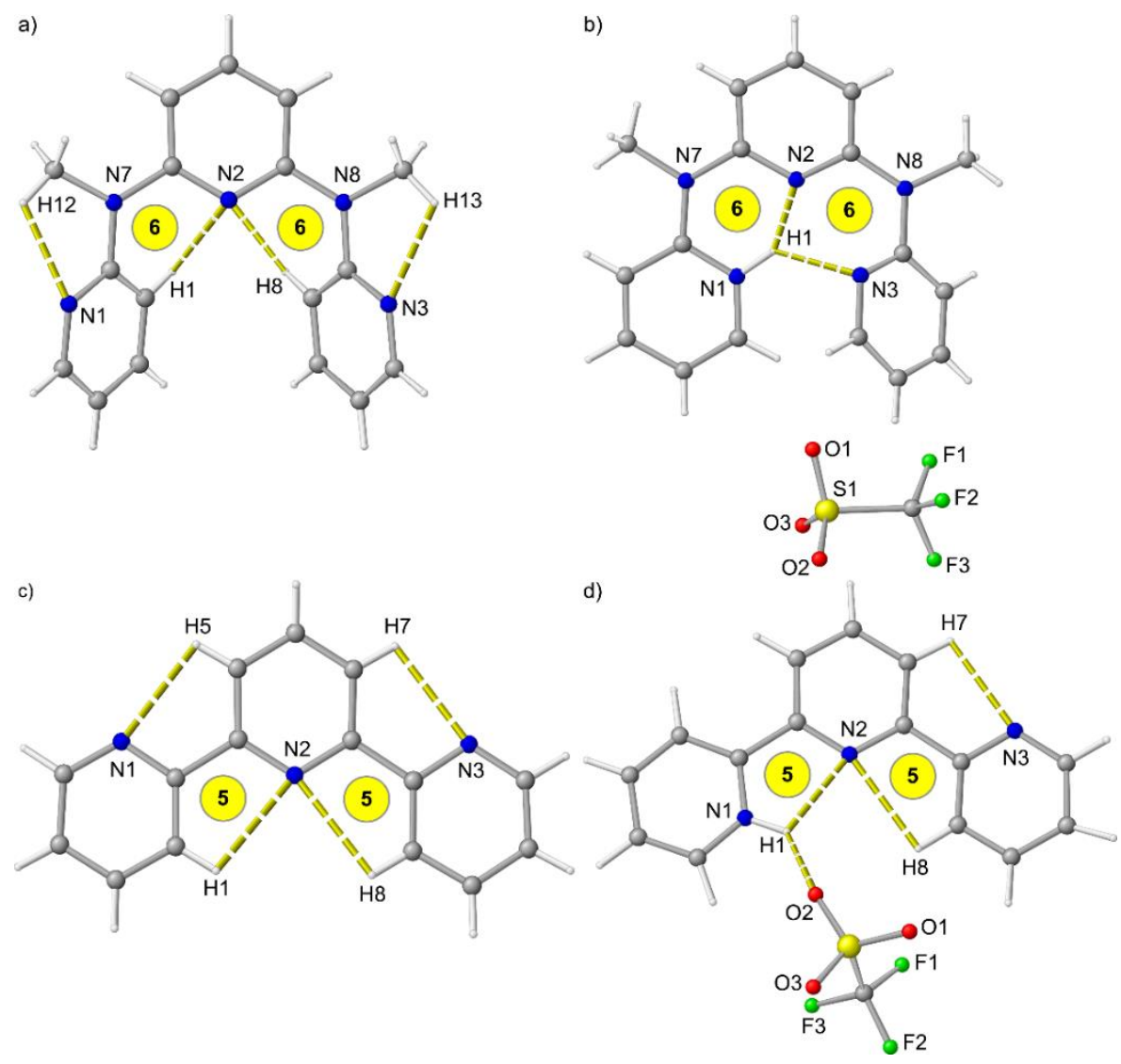

Figure 1. Molecular structures of (a) ddpd, (b) [H-ddpd] $\left[\mathrm{CF}_{3} \mathrm{SO}_{3}\right]$, (c) tpy [44] and (d) [H-tpy] $\left[\mathrm{CF}_{3} \mathrm{SO}_{3}\right][48]$ in the solid state. Hydrogen bonds indicated by yellow dashed lines. Atom numbering unified for clarity. Ring sizes involving the central pyridine highlighted in yellow. 
A computational study of $\mathrm{Ni}(\mathrm{CO})_{3}\left(\kappa N 1\right.$-ddpd), $\mathrm{Ni}(\mathrm{CO})_{3}(\mathrm{kN2}$-ddpd) complexes and other $\mathrm{Ni}(\mathrm{CO})_{3}(\mathrm{~L})$ complexes revealed that the net donor strength $(\sigma+\pi)$ of ddpd donor atoms ranks between that of trimethylamine and $N$-heterocyclic carbene ligands and is larger than that of pyridine, as estimated from the Density Functional Theory (DFT) calculated $\mathrm{A}_{1}$ carbonyl stretching modes of the $\mathrm{Ni}(\mathrm{CO})_{3}$ fragments [35]. Obviously, ddpd is a stronger Lewis base and a stronger Brønsted base than tpy.

The ligand ddpd is fluorescent in solution $\left(\lambda_{\max }=398 \mathrm{~nm} ; \Phi=8.0 \%, \tau=3.0 \mathrm{~ns}\right.$ in $\mathrm{CH}_{3} \mathrm{CN}$; $\lambda_{\max }=410 \mathrm{~nm}$ in acid-free $\mathrm{CH}_{2} \mathrm{Cl}_{2}$ ) [49,50]. In acidic $\mathrm{CH}_{2} \mathrm{Cl}_{2}$ or in the intentional presence of acid, the emission band shifts to $395 \mathrm{~nm}(\tau=4.0 \mathrm{~ns})$ [49]. In contrast, protonation of tpy in $\mathrm{CH}_{3} \mathrm{CN}$ shifts its emission band from $340 \mathrm{~nm}$ to $412 \mathrm{~nm}$ (25.6 ns) [51].

In line with the electron donating character of the N-Me groups, ddpd is very difficult to reduce to its radical anion ddpd ${ }^{-}$(peak potential $-3.27 \mathrm{~V}$ vs. ferrocene in $\mathrm{CH}_{3} \mathrm{CN}$ ) [49]. On the other hand, tpy is reversibly reduced to tpy $\cdot^{-}$at $-2.55 \mathrm{~V}$ versus ferrocene in $\mathrm{CH}_{3} \mathrm{CN}$ [52]. The relative ease of reduction causes the typical redox non-innocent behaviour of tpy in many first-row transition metal complexes [23-27]. The electron rich ddpd ligand in contrast should behave essentially redox-innocent in transition metal complexes. Oxidation of ddpd's $\mathrm{N}-\mathrm{Me}$ groups to the radical cations is irreversible with peak potentials at $0.55 \mathrm{~V}$ and $1.06 \mathrm{~V}$ versus ferrocene in $\mathrm{CH}_{3} \mathrm{CN}$ [49].

Typical synthetic procedures for homoleptic $\left[\mathrm{M}(\mathrm{ddpd})_{2}\right]^{2+}$ complexes employ the tetrafluoroborate salts of the respective metal ions, such as $\mathrm{Zn}\left[\mathrm{BF}_{4}\right]_{2} \times 6 \mathrm{H}_{2} \mathrm{O}$ or $\mathrm{Fe}\left[\mathrm{BF}_{4}\right]_{2} \times 6 \mathrm{H}_{2} \mathrm{O}$ or the respective metal chlorides such as $\mathrm{CrCl}_{2}$ (Scheme 3). Suitable oxidants (oxygen, silver triflate, ceric ammonium nitrate, 2,3-dichloro-5,6-dicyano-1,4-benzoquinone) oxidize $\left[\mathrm{M}(\mathrm{ddpd})_{2}\right]^{2+}$ to the $+\mathrm{III}$ oxidation state in $\left[\mathrm{M}(\mathrm{ddpd})_{2}\right]^{3+}$ (Scheme 3).

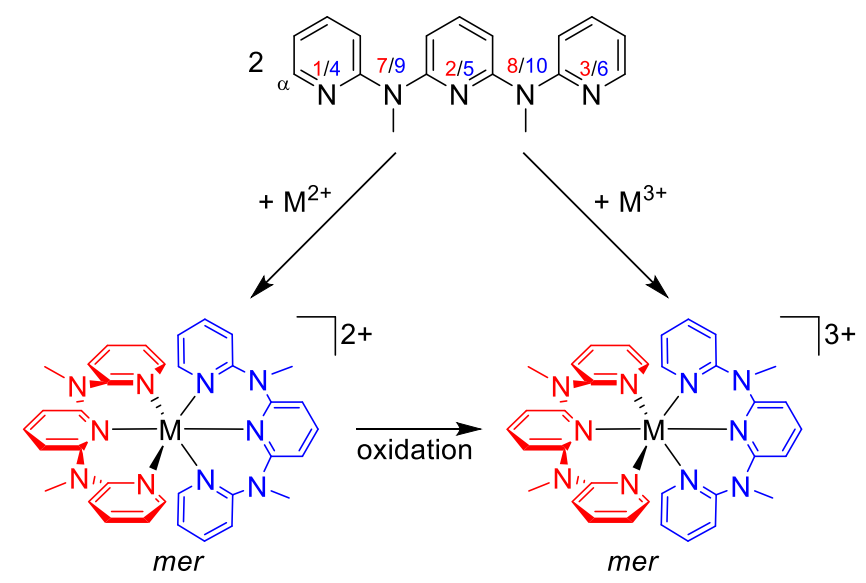

Scheme 3. General synthetic procedures for $\left[\mathrm{M}(\mathrm{ddpd})_{2}\right]^{n+}$ complexes $(n=2,3)$ and atom numbering.

The rigid five-membered $\mathrm{C}_{2} \mathrm{~N}_{2} \mathrm{M}$ chelate rings formed by tpy ligands merely allow for a meridional coordination in homoleptic complexes $\left[\mathrm{M}(\mathrm{tpy})_{2}\right]^{n+}$. In contrast, the more flexible six-membered $\mathrm{C}_{2} \mathrm{~N}_{3} \mathrm{M}$ chelate rings formed by ddpd ligands enable both meridional and facial coordination modes, that is, a pincer-type [1] or a tripodal topology (Scheme 4a). In fact, mer isomers of $\left[\mathrm{M}(\mathrm{ddpd})_{2}\right]^{n+}$ complexes appear to be more prevalent but cis-fac isomers have been observed as well. The six-membered chelate rings in the ddpd complexes form boat conformations. The metal centre $\mathrm{M}$ and the N-Me group (N7, N9) lie above the mean plane of the ring (Scheme 4a). 


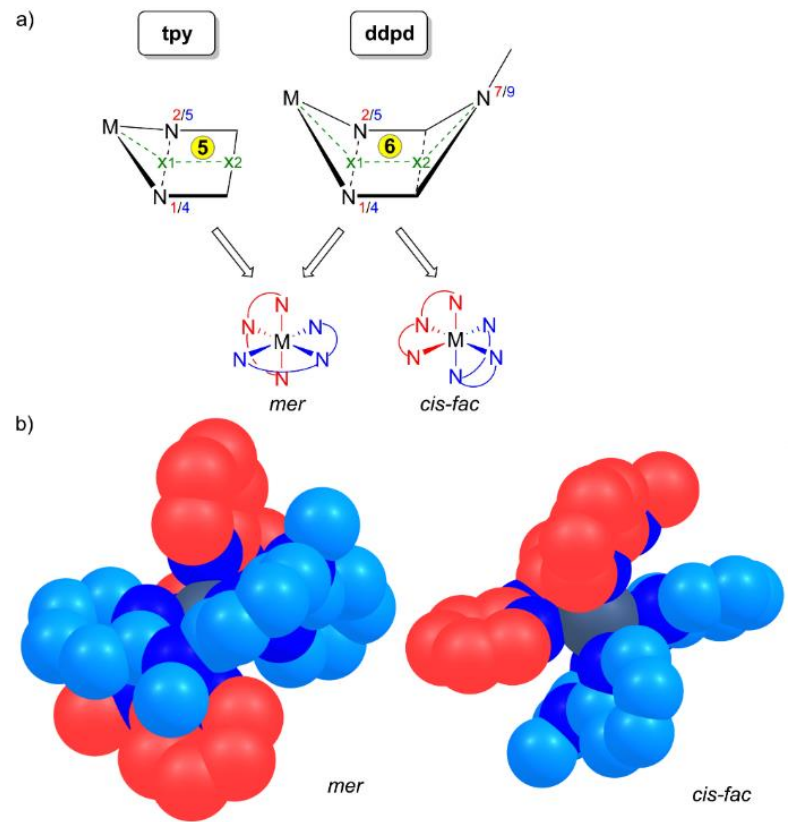

Scheme 4. (a) Chelate ring size (5 for tpy; 6 for ddpd) and corresponding envelope and boat conformations and the resulting conceivable mer and cis-fac stereoisomers and (b) space-filling models of mer and cis-fac stereoisomers of $\left[\mathrm{M}(\mathrm{ddpd})_{2}\right]^{n+}$ with the two ligands color-coded red and blue, respectively. For numbering of nitrogen atoms see Scheme 3. Hydrogen atoms omitted for clarity.

The $\mathrm{M}-\mathrm{x} 1-\mathrm{x} 2$ and $\mathrm{N} 7 / 9-\mathrm{x} 2-\mathrm{x} 1$ angles vary between $139^{\circ}$ and $145^{\circ}$. On the other hand, the chelates formed by tpy are essentially planar with $\mathrm{M}-\mathrm{x} 1-\mathrm{x} 2$ angles approaching $180^{\circ}$ (Scheme $\left.4 \mathrm{a}\right)$. The $\mathrm{N}-\mathrm{M}-\mathrm{N}$ bite angles of ddpd are significantly larger $\left(80-89^{\circ}\right)$ than that of tpy with $75-82^{\circ}$ (Tables 1 and 2). With the tpy ligand and the five-membered chelates being planar, the point group of $\left[\mathrm{M}(\mathrm{tpy})_{2}\right]^{n+}$ complexes is $C_{2 \mathrm{v}}$. As ddpd is a non-planar ligand in homo- and heteroleptic complexes, the point group of $\left[\mathrm{M}(\mathrm{ddpd})_{2}\right]^{n+}$ complexes is only $C_{2}$. Consequently, mer-[M(ddpd $\left.)_{2}\right]^{n+}$ complexes are chiral with helical chirality (Scheme $4 b)$. Mixed ruthenium(II) complexes $[R u(d d p d)(t p y-X)]^{2+}$ form diastereomeric ion pairs with chiral enantiopure counterions [33]. Racemic mer-[Cr(ddpd $\left.)_{2}\right]^{3+}$ complexes can be partially resolved into the corresponding $P$ and $M$ enantiomers. These seem to be configurationally stable on the HPLC timescale [53]. The isomeric cis-fac-[M(ddpd $\left.)_{2}\right]^{n+}$ complexes are chiral as well (Scheme $4 \mathrm{~b}$ ) and have been isolated only as racemic mixtures so far. In the following, all mer- and cis-fac- $\left[\mathrm{M}(\mathrm{ddpd})_{2}\right]^{n+}$ complexes are racemic mixtures and this will not be indicated explicitly.

All homoleptic complexes $\left[\mathrm{M}(\mathrm{ddpd})_{2}\right]^{n+}$ and $\left[\mathrm{M}(\mathrm{tpy})_{2}\right]^{n+}$ share a $\left[\mathrm{MN}_{6}\right]$ coordination sphere. The deviation of the experimental coordination geometry from the ideal octahedron can be expressed by a continuous shape measure $S($ OC-6) as implemented in the program SHAPE 2.1 (free download at http:/ / www.ee.ub.es) [54-58]. For an ideal octahedron, this value will be zero and increases with the structural deviation. The higher flexibility and thus higher adaptability of the six-membered chelate rings of ddpd allow for $\mathrm{N}-\mathrm{M}-\mathrm{N}$ angles closer to $90^{\circ}$ and for similar $\mathrm{M}-\mathrm{N}$ distances and thus enable "more octahedral" coordination geometries. The rigid pincer ligand tpy features smaller N-M-N angles and significantly differing $\mathrm{M}-\mathrm{N}$ distances to the central and terminal pyridines yielding much more distorted coordination polyhedrons. This is clearly obvious from the significantly larger shape measure $S(\mathrm{OC}-6)$ of $\left[\mathrm{M}(\mathrm{tpy})_{2}\right]^{n+}$ complexes as compared to analogous $\left[\mathrm{M}(\mathrm{ddpd})_{2}\right]^{n+}$ complexes (Tables 1 and 2). Interestingly, the $S(\mathrm{OC}-6)$ values increase along the series $\mathrm{Fe}^{\mathrm{II}} / \mathrm{Co}^{\mathrm{III}}<\mathrm{Cr}^{\mathrm{III}}<\mathrm{Ni}^{\mathrm{II}}<\mathrm{Co}^{\mathrm{II}}<\mathrm{Cu}^{\mathrm{II}}<\mathrm{Zn}^{\mathrm{II}}$ in both ligand series, suggesting that this trend is coded in the d electron configuration of the metal ion (low-spin $\mathrm{d}^{6}, \mathrm{~d}^{3}, \mathrm{~d}^{8}$, high-spin $\mathrm{d}^{7}, \mathrm{~d}^{9}, \mathrm{~d}^{10}$ ), especially in the occupation of the e ${ }_{\mathrm{g}}{ }^{*}$ orbitals and in the presence of Jahn-Teller effects [59]. $\left[\mathrm{Cr}(\mathrm{L})_{2}\right]^{2+}$ complexes feature different electron distributions for $\mathrm{L}=\mathrm{ddpd}$ and tpy as will be discussed below. 
Specific to ddpd are the bridging three-coordinate nitrogen atoms N7/N8 and N9/N10 and their respective degree of planarization as defined by $P L / \%=100 \times\{[\Sigma(\mathrm{X}-\mathrm{N}-\mathrm{Y})]-3 \times$ $\left.\left.109.5^{\circ}\right] /\left[3 \times 120.0^{\circ}-3 \times 109.5^{\circ}\right]\right\}$ [43]. In ddpd as well as in [H-ddpd $]^{+}$, these $\mathrm{N}$ atoms are in a planar environment with $P L=100 \%$, while in the homoleptic complexes mer-[M(ddpd $\left.)_{2}\right]^{n+}$ the degree of planarization varies between $81 \%$ and $93 \%$ (Table 1 ). This indicates that metal chelation induces some strain in the ligand.

Table 1. Relevant metrical data of $\left[\mathrm{M}(\mathrm{ddpd})_{2}\right]^{n+}$ ions in the solid state; mer isomers if not indicated otherwise; $\left[\mathrm{BF}_{4}\right]^{-}$salts if not indicated otherwise; distances in $\AA, P L$ in \% and angles in ${ }^{\circ}$. Red and blue color code indicates the different ddpd ligands (see Scheme 3 ).

\begin{tabular}{|c|c|c|c|c|c|c|c|}
\hline \multicolumn{4}{|c|}{$\mathrm{L}=\operatorname{ddpd}(\mathrm{A})$} & \multicolumn{3}{|c|}{$L=\operatorname{ddpd}(B)$} & \multirow[b]{2}{*}{$S(\mathrm{OC}-6)^{[\mathrm{g}]}$} \\
\hline $\mathbf{M}$ & $\begin{array}{l}\text { M-N1/ } \\
\text { M-N2/ } \\
\text { M-N3 }\end{array}$ & $\begin{array}{l}\text { PL N7/ } \\
\text { PL N8 }\end{array}$ & $\begin{array}{l}\text { N1-M-N2/ } \\
\text { N1-M-N3/ } \\
\text { N2-M-N3 }\end{array}$ & $\begin{array}{l}\text { M-N4/ } \\
\text { M-N5/ } \\
\text { M-N6 }\end{array}$ & $\begin{array}{l}P L \text { N9/ } \\
P L \text { N10 }\end{array}$ & $\begin{array}{l}\text { N4-M-N5/ } \\
\text { N4-M-N6/ } \\
\text { N5-M-N6 }\end{array}$ & \\
\hline $\mathrm{Zn}{ }^{\mathrm{II}}[49]$ & $\begin{array}{c}2.1427(16) / \\
2.127(2) / \\
2.1427(16)\end{array}$ & $\begin{array}{c}88 / \\
88\end{array}$ & $\begin{array}{c}82.40(4) / \\
164.79(8) / \\
82.40(4)\end{array}$ & $\begin{array}{c}2.1427(16) / \\
2.127(2) / \\
2.1427(16)\end{array}$ & $\begin{array}{c}88 / \\
88\end{array}$ & $\begin{array}{c}82.40(4) / \\
164.79(8) / \\
82.40(4)\end{array}$ & 1.18 \\
\hline $\mathrm{Cu}^{\mathrm{II}[\mathrm{a}]}[60]$ & $\begin{array}{c}2.149(5) / \\
2.064(5) / \\
2.149(5)\end{array}$ & $\begin{array}{c}93 / \\
93\end{array}$ & $\begin{array}{l}83.25(12) / \\
166.5(2) / \\
83.25(12)\end{array}$ & $\begin{array}{c}2.191(4) / \\
1.978(6) / \\
2.191(4) \\
\end{array}$ & $\begin{array}{c}81 / \\
81\end{array}$ & $\begin{array}{l}83.51(12) / \\
167.0(2) / \\
83.51(12)\end{array}$ & 1.11 \\
\hline $\mathrm{Cu}^{\mathrm{II}[\mathrm{b}]}[60]$ & $\begin{array}{c}2.0256(15) / \\
1.989(3) / \\
2.0256(15)\end{array}$ & $\begin{array}{c}91 / \\
91\end{array}$ & $\begin{array}{c}86.06(5) / \\
172.12(9) / \\
86.06(5)\end{array}$ & $\begin{array}{c}2.3318(16) / \\
2.060(3) / \\
2.3318(16)\end{array}$ & $\begin{array}{c}90 / \\
90\end{array}$ & $\begin{array}{c}80.03(4) / \\
160.06(8) / \\
80.03(4)\end{array}$ & 1.60 \\
\hline $\mathrm{Ni}^{\mathrm{II}}[61]$ & $\begin{array}{c}2.0922(15) / \\
2.058(2) / \\
2.0922(15)\end{array}$ & $\begin{array}{c}88 / \\
88\end{array}$ & $\begin{array}{c}84.64(4) / \\
169.28(8) / \\
84.64(4)\end{array}$ & $\begin{array}{c}2.0922(15) / \\
2.058(2) / \\
2.0922(15)\end{array}$ & $\begin{array}{c}88 / \\
88\end{array}$ & $\begin{array}{c}84.64(4) / \\
169.28(8) / \\
84.64(4)\end{array}$ & 0.60 \\
\hline $\mathrm{Co}^{\mathrm{II}}[62]$ & $\begin{array}{c}2.1199(19) / \\
2.090(2) / \\
2.1199(19)\end{array}$ & $\begin{array}{c}88 / \\
88\end{array}$ & $\begin{array}{c}83.19(5) / \\
166.38(10) / \\
83.19(5)\end{array}$ & $\begin{array}{c}2.1199(19) / \\
2.090(2) / \\
2.1199(19)\end{array}$ & $\begin{array}{c}88 / \\
88\end{array}$ & $\begin{array}{c}83.19(5) / \\
166.38(10) / \\
83.19(5)\end{array}$ & 0.95 \\
\hline $\mathrm{Co}^{\mathrm{II}[\mathrm{c}]}[63]$ & $\begin{array}{c}2.20(2) / \\
2.19(2) / \\
2.14(2)\end{array}$ & $\begin{array}{c}97 / \\
96\end{array}$ & $\begin{array}{c}83.6(8) / \\
94.4(7) / \\
83.0(8)\end{array}$ & $\begin{array}{c}2.25(2) / \\
2.11(2) / \\
2.19(2)\end{array}$ & $\begin{array}{c}99 / \\
92\end{array}$ & $\begin{array}{c}81.3(8) / \\
94.3(8) / \\
81.7(8)\end{array}$ & 0.81 \\
\hline $\mathrm{Co}^{\mathrm{III}[\mathrm{d}]}$ & $\begin{array}{c}1.954(3) / \\
1.942(3) / \\
1.952(3)\end{array}$ & $\begin{array}{l}89 / \\
88\end{array}$ & $\begin{array}{c}87.66(14) / \\
176.18(15) / \\
88.54(14)\end{array}$ & $\begin{array}{c}1.947(3) / \\
1.945(3) / \\
1.941(3)\end{array}$ & $\begin{array}{l}87 / \\
84\end{array}$ & $\begin{array}{c}87.92(15) / \\
175.85(16) / \\
87.93(14)\end{array}$ & 0.10 \\
\hline $\mathrm{Fe}^{\mathrm{II}}[64]$ & $\begin{array}{c}1.9938(17) / \\
1.963(2) / \\
1.9938(17)\end{array}$ & $\begin{array}{l}89 / \\
89\end{array}$ & $\begin{array}{c}87.73(5) / \\
175.46(9) / \\
87.73(5)\end{array}$ & $\begin{array}{c}1.9938(17) / \\
1.963(2) / \\
1.9938(17)\end{array}$ & $\begin{array}{c}89 / \\
89\end{array}$ & $\begin{array}{c}87.73(5) / \\
175.46(9) / \\
87.73(5)\end{array}$ & 0.12 \\
\hline $\mathrm{Fe}^{\mathrm{II}[\mathrm{f}]}[64]$ & $\begin{array}{c}1.9939(18) / \\
1.9593(18) / \\
1.9922(18)\end{array}$ & $\begin{array}{l}89 / \\
88\end{array}$ & $\begin{array}{c}88.39(7) / \\
177.01(8) / \\
88.63(7)\end{array}$ & $\begin{array}{c}1.9921(19) / \\
1.9661(18) / \\
1.9855(19)\end{array}$ & $\begin{array}{l}89 / \\
84\end{array}$ & $\begin{array}{c}88.89(8) / \\
176.48(7) / \\
88.23(8)\end{array}$ & 0.08 \\
\hline $\mathrm{Fe}^{\Pi I[\mathrm{~d}, \mathrm{e}]}$ & $\begin{array}{c}1.983(3) / \\
1.964(5) / \\
1.983(3)\end{array}$ & $\begin{array}{l}87 / \\
87\end{array}$ & $\begin{array}{c}87.90(10) / \\
175.8(2) / \\
87.90(10)\end{array}$ & $\begin{array}{c}1.983(3) / \\
1.964(5) / \\
1.983(3)\end{array}$ & $\begin{array}{l}87 / \\
87\end{array}$ & $\begin{array}{l}87.90(10) / \\
175.8(2) / \\
87.90(10)\end{array}$ & 0.10 \\
\hline $\mathrm{Cr}^{I I[\mathrm{~d}]}$ & $\begin{array}{c}2.117(7) / \\
2.070(11) / \\
2.117(7) \\
\end{array}$ & $\begin{array}{l}87 / \\
87\end{array}$ & $\begin{array}{c}83.4(2) / \\
166.7(4) / \\
83.4(2) \\
\end{array}$ & $\begin{array}{c}2.089(6) / \\
2.064(9) / \\
2.089(6) \\
\end{array}$ & $\begin{array}{c}88 / \\
88\end{array}$ & $\begin{array}{c}84.8(2) / \\
169.7(4) / \\
84.8(2) \\
\end{array}$ & 0.74 \\
\hline $\mathrm{Cr}^{\mathrm{III}}[50]$ & $\begin{array}{c}2.0485(18) / \\
2.0393(18) / \\
2.0394(19)\end{array}$ & $\begin{array}{l}82 / \\
88\end{array}$ & $\begin{array}{c}85.13(8) / \\
170.86(8) / \\
85.74(7)\end{array}$ & $\begin{array}{c}2.0446(17) / \\
2.0444(18) / \\
2.0485(18)\end{array}$ & $\begin{array}{c}87 / \\
88\end{array}$ & $\begin{array}{c}85.89(7) / \\
170.88(7) / \\
84.99(7)\end{array}$ & 0.43 \\
\hline $\begin{array}{c}\mathrm{Cr}^{\mathrm{III}[\mathrm{f}]} \\
\text { mol.A [50] }\end{array}$ & $\begin{array}{c}2.041(6) / \\
2.054(7) / \\
2.028(6)\end{array}$ & $\begin{array}{l}81 / \\
87\end{array}$ & $\begin{array}{c}85.7(2) / \\
172.3(3) / \\
86.7(3)\end{array}$ & $\begin{array}{c}2.040(7) / \\
2.054(7) / \\
2.048(7)\end{array}$ & $\begin{array}{c}85 / \\
90\end{array}$ & $\begin{array}{c}85.4(3) / \\
171.0(3) / \\
85.6(3)\end{array}$ & 0.37 \\
\hline $\begin{array}{c}\mathrm{Cr}^{\mathrm{III}[\mathrm{f}]} \\
\text { mol. B [50] }\end{array}$ & $\begin{array}{c}2.039(7) / \\
2.030(7) / \\
2.033(7) \\
\end{array}$ & $\begin{array}{l}88 / \\
84\end{array}$ & $\begin{array}{c}86.8(3) / \\
172.6(3) / \\
86.0(3) \\
\end{array}$ & $\begin{array}{c}2.040(6) / \\
2.046(7) / \\
2.030(6)\end{array}$ & $\begin{array}{c}84 / \\
80\end{array}$ & $\begin{array}{c}85.5(3) / \\
173.0(3) / \\
87.5(3)\end{array}$ & 0.29 \\
\hline $\mathrm{V}^{\mathrm{III}[\mathrm{c}, \mathrm{d}, \mathrm{f}]}$ & $\begin{array}{c}2.104(8) / \\
2.054(8) / \\
2.121(9)\end{array}$ & $\begin{array}{l}88 / \\
94\end{array}$ & $\begin{array}{l}81.3(3) / \\
92.3(3) / \\
84.6(4)\end{array}$ & $\begin{array}{c}2.101(7) / \\
2.036(8) / \\
2.106(8)\end{array}$ & $\begin{array}{c}86 / \\
90\end{array}$ & $\begin{array}{l}82.7(3) / \\
95.0(3) / \\
84.0(3)\end{array}$ & 0.64 \\
\hline
\end{tabular}

${ }^{[a]}$ At $263 \mathrm{~K} .{ }^{[\mathrm{b}]}$ At $123 \mathrm{~K} .{ }^{[\mathrm{c}]}$ cis-fac isomer. ${ }^{[\mathrm{d}]}$ This work. ${ }^{[\mathrm{e}]} \mathrm{Br}^{-}$salt. ${ }^{[\mathrm{f}]}\left[\mathrm{PF}_{6}\right]^{-}$salt. ${ }^{[\mathrm{g}]}$ Continuous shape measure [54]. 
Table 2. Relevant metrical data of $\left[\mathrm{M}(\mathrm{tpy})_{2}\right]^{n+}$ ions in the solid state; $\left[\mathrm{BF}_{4}\right]^{-}$salts if not indicated otherwise, distances in $\AA$ and angles in ${ }^{\circ}$. Red and blue color code indicates the different tpy ligands.

\begin{tabular}{|c|c|c|c|c|c|}
\hline \multirow[b]{2}{*}{$\mathbf{M}$} & \multicolumn{2}{|c|}{$\mathrm{L}=\operatorname{tpy}(\mathrm{A})$} & \multicolumn{2}{|c|}{$L=\operatorname{tpy}(B)$} & \multirow[b]{2}{*}{$S(\mathrm{OC}-6)^{[\mathrm{e}]}$} \\
\hline & $\begin{array}{l}\text { M-N1/ } \\
\text { M-N2/ } \\
\text { M-N3 }\end{array}$ & $\begin{array}{l}\text { N1-M-N2/ } \\
\text { N1-M-N3/ } \\
\text { N2-M-N3 }\end{array}$ & $\begin{array}{l}\text { M-N4/ } \\
\text { M-N5/ } \\
\text { M-N6 }\end{array}$ & $\begin{array}{l}\text { N4-M-N5/ } \\
\text { N4-M-N6/ } \\
\text { N5-M-N6 }\end{array}$ & \\
\hline $\mathrm{Zn}^{\mathrm{II}[\mathrm{a}]}[65]$ & $\begin{array}{c}2.1952(15) / \\
2.089(2) / \\
2.1952(15)\end{array}$ & $\begin{array}{c}75.16(4) / \\
150.31(8) / \\
75.16(4)\end{array}$ & $\begin{array}{c}2.1882(15) / \\
2.089(2) / \\
2.1882(15)\end{array}$ & $\begin{array}{c}75.36(4) / \\
150.71(9) / \\
75.36(4)\end{array}$ & 4.46 \\
\hline $\mathrm{Cu}^{\mathrm{II}}[66]$ & $\begin{array}{c}2.225(6) / \\
2.061(5) / \\
2.232(6)\end{array}$ & $\begin{array}{c}77.8(2) / \\
154.4(2) / \\
76.7(2)\end{array}$ & $\begin{array}{c}2.207(5) / \\
1.971(9) / \\
2.224(5)\end{array}$ & $\begin{array}{c}76.9(2) / \\
153.6(2) / \\
76.8(2)\end{array}$ & 3.70 \\
\hline $\mathrm{Ni}^{\mathrm{II}[\mathrm{c}]}[67]$ & $\begin{array}{c}2.110(2) / \\
1.999(2) / \\
2.119(2)\end{array}$ & $\begin{array}{c}78.00(8) / \\
155.42(8) / \\
77.50(8)\end{array}$ & $\begin{array}{l}2.120(2) / \\
2.000(2) / \\
2.117(2)\end{array}$ & $\begin{array}{c}77.40(8) / \\
155.37(8) / \\
78.06(8)\end{array}$ & 3.18 \\
\hline $\mathrm{Co}^{\mathrm{II}}[68]$ & $\begin{array}{c}2.151(3) / \\
2.013(5) / \\
2.147(3)\end{array}$ & $\begin{array}{c}77.11(14) / \\
154.30(13) / \\
77.21(15)\end{array}$ & $\begin{array}{c}2.141(3) / \\
2.003(4) / \\
2.153(3)\end{array}$ & $\begin{array}{c}76.46(12) / \\
153.34(12) / \\
77.01(12)\end{array}$ & 3.62 \\
\hline $\begin{array}{c}\mathrm{Co}^{\mathrm{III}[\mathrm{b}]} \\
\mathrm{mol} \mathrm{A}[68]\end{array}$ & $\begin{array}{c}1.9545(16) / \\
1.8590(16) / \\
1.9408(16)\end{array}$ & $\begin{array}{c}82.60(7) / \\
164.93(7) / \\
82.46(7)\end{array}$ & $\begin{array}{c}1.9595(16) / \\
1.8596(16) / \\
1.9369(16)\end{array}$ & $\begin{array}{c}82.51(7) / \\
165.08(7) / \\
82.66(7)\end{array}$ & 1.22 \\
\hline $\begin{array}{c}\mathrm{Co}^{\mathrm{III}}[\mathrm{b}] \\
\mathrm{mol} \mathrm{B}[68]\end{array}$ & $\begin{array}{c}1.9348(15) / \\
1.8550(15) / \\
1.9440(15)\end{array}$ & $\begin{array}{c}83.06(7) / \\
165.54(7) / \\
82.50(7)\end{array}$ & $\begin{array}{c}1.9457(15) / \\
1.8555(15) / \\
1.9474(16)\end{array}$ & $\begin{array}{c}82.87(7) / \\
165.55(7) / \\
82.74(7)\end{array}$ & 1.15 \\
\hline $\mathrm{Fe}^{\mathrm{II}[\mathrm{c}]}[69]$ & $\begin{array}{l}1.990(3) / \\
1.888(3) / \\
1.990(3)\end{array}$ & $\begin{array}{c}80.60(13) / \\
161.45(12) / \\
80.94(12)\end{array}$ & $\begin{array}{l}1.988(3) / \\
1.887(3) / \\
1.981(3)\end{array}$ & $\begin{array}{c}80.88(12) / \\
161.64(12) / \\
80.87(12)\end{array}$ & 1.81 \\
\hline $\mathrm{Mn}^{\mathrm{II}}[\mathrm{c}][70]$ & $\begin{array}{c}2.269(2) / \\
2.196(2) / \\
2.257(2)\end{array}$ & $\begin{array}{c}72.09(7) / \\
144.45(8) / \\
72.36(7)\end{array}$ & $\begin{array}{c}2.246(2) / \\
2.178(2) / \\
2.249(2)\end{array}$ & $\begin{array}{c}72.68(7) / \\
144.70(8) / \\
72.47(7)\end{array}$ & 6.70 \\
\hline $\mathrm{Mn}^{\mathrm{III}[\mathrm{b}, \mathrm{d}]}[70]$ & $\begin{array}{c}2.1238(13) / \\
1.9749(12) / \\
2.1087(13)\end{array}$ & $\begin{array}{c}77.31(5) / \\
155.03(5) / \\
77.93(5)\end{array}$ & $\begin{array}{c}2.1238(13) / \\
1.9749(12) / \\
2.1087(13)\end{array}$ & $\begin{array}{c}77.31(5) / \\
155.03(5) / \\
77.93(5)\end{array}$ & 3.42 \\
\hline $\begin{array}{c}\mathrm{Cr}^{\mathrm{II} "}[\mathrm{~b}] \\
\mathrm{mol} \mathrm{A} \\
{[27]}\end{array}$ & $\begin{array}{c}2.049(4) / \\
1.916(4) / \\
2.033(4)\end{array}$ & $\begin{array}{c}79.28(15) / \\
158.19(15) / \\
78.94(15)\end{array}$ & $\begin{array}{l}2.060(4) / \\
1.997(4) / \\
2.069(4)\end{array}$ & $\begin{array}{c}78.07(14) / \\
156.50(15) / \\
78.43(14)\end{array}$ & 2.68 \\
\hline $\begin{array}{c}\text { "CrII" [b] } \\
\text { mol B } \\
{[27]}\end{array}$ & $\begin{array}{c}2.036(4) / \\
1.919(4) / \\
2.053(4)\end{array}$ & $\begin{array}{c}78.83(15) / \\
157.59(16) / \\
78.80(15)\end{array}$ & $\begin{array}{l}2.073(4) / \\
2.006(4) / \\
2.062(4)\end{array}$ & $\begin{array}{c}78.01(15) / \\
156.12(16) / \\
78.18(14)\end{array}$ & 2.80 \\
\hline $\begin{array}{c}\mathrm{Cr}^{\mathrm{III}[\mathrm{b}]} \\
\mathrm{mol} \mathrm{A}[71]\end{array}$ & $\begin{array}{l}2.054(3) / \\
2.042(3) / \\
2.058(4)\end{array}$ & $\begin{array}{c}78.78(14) / \\
157.06(14) / \\
78.34(14)\end{array}$ & $\begin{array}{c}2.042(3) / \\
1.987(3) / \\
2.062(4)\end{array}$ & $\begin{array}{c}79.00(14) / \\
157.17(14) / \\
78.22(15)\end{array}$ & 2.73 \\
\hline $\begin{array}{c}\mathrm{Cr}^{\mathrm{III}}[\mathrm{b}] \\
\mathrm{mol} \mathrm{B} \\
{[71]}\end{array}$ & $\begin{array}{c}2.055(3) / \\
1.976(3) / \\
2.057(3)\end{array}$ & $\begin{array}{c}79.01(13) / \\
158.24(13) / \\
79.29(14)\end{array}$ & $\begin{array}{l}2.062(3) / \\
1.989(3) / \\
2.042(3)\end{array}$ & $\begin{array}{c}79.12(13) / \\
157.98(13) / \\
78.97(14)\end{array}$ & 2.57 \\
\hline $\begin{array}{c}\mathrm{Cr}^{\mathrm{III}}[\mathrm{b}] \\
\mathrm{mol} \mathrm{C} \\
{[71]}\end{array}$ & $\begin{array}{l}2.099(4) / \\
2.003(4) / \\
2.035(4)\end{array}$ & $\begin{array}{c}77.39(15) / \\
156.93(16) / \\
79.59(17)\end{array}$ & $\begin{array}{c}2.063(4) / \\
1.983(3) / \\
2.049(3)\end{array}$ & $\begin{array}{c}78.37(14) / \\
157.19(14) / \\
78.92(14)\end{array}$ & 2.74 \\
\hline $\begin{array}{c}\mathrm{Cr}^{\mathrm{III}[\mathrm{b}]} \\
\mathrm{mol} \mathrm{D} \\
{[71]}\end{array}$ & $\begin{array}{c}2.039(4) / \\
1.981(4) / \\
2.049(4)\end{array}$ & $\begin{array}{c}78.80(15) / \\
157.98(16) / \\
79.41(15)\end{array}$ & $\begin{array}{l}2.053(4) / \\
1.978(4) / \\
2.057(4)\end{array}$ & $\begin{array}{c}78.43(15) / \\
157.76(15) / \\
79.38(15)\end{array}$ & 2.63 \\
\hline
\end{tabular}

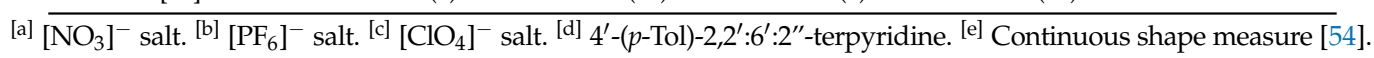

In the solid state, $\left[\mathrm{M}(\mathrm{tpy})_{2}\right]^{2+}$ complexes exhibit characteristic edge-to-face $(e f)$ and offset-face-to-face (off) interactions between the outer pyridine rings of the essentially planar aromatic tridentate ligands (terpyridine embrace, Figure 2a) $[68,72]$. Similarly, $\left[\mathrm{M}(\mathrm{ddpd})_{2}\right]^{2+}$ cations pack in the solid state displaying characteristic ef-off-ef interactions between the (non-planar) ddpd ligands of neighbouring complexes. The off interaction occurs between two outer pyridine rings and the two ef interactions between central and outer pyridines (Figure $2 b$ ). 


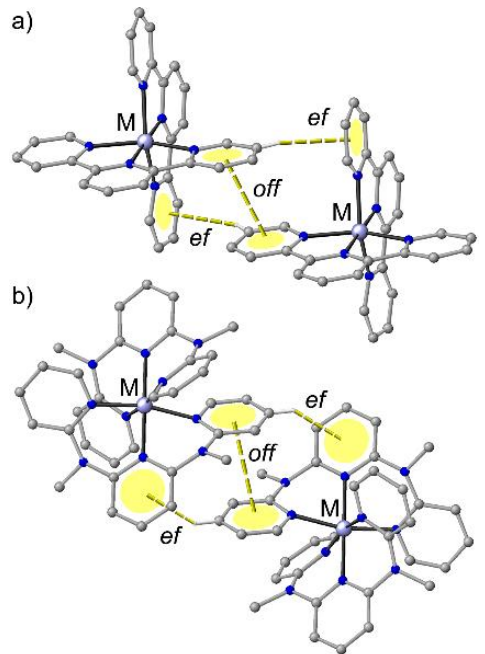

Figure 2. General motifs of phenyl embraces of (a) $\left[\mathrm{M}(\mathrm{tpy})_{2}\right]^{2+}$ and (b) $\left[\mathrm{M}(\mathrm{ddpd})_{2}\right]^{2+}$ complexes.

In essence, the main differences between tpy and ddpd are the stronger electron donating and weaker electron accepting character of ddpd in addition to its higher flexibility and larger N-M-N bite angles. In the following chapters, the translation of these key differences of the tridentate oligopyridine ligands into different properties of first row transition metal ddpd and tpy complexes will be elaborated in more detail.

\section{3. $m e r-\left[\mathrm{Zn}(\mathrm{ddpd})_{2}\right]^{2+}$ and $\mathrm{ZnCl}_{2}(\mathrm{ddpd})\left[\mathrm{d}^{10}\right]$}

The $\left[\mathrm{Zn}(\mathrm{L})_{2}\right]^{2+}$ complexes are conveniently prepared from $\mathrm{Zn}\left[\mathrm{BF}_{4}\right]_{2} \times 6 \mathrm{H}_{2} \mathrm{O}$ or $\mathrm{Zn}\left[\mathrm{ClO}_{4}\right]_{2} \times 6 \mathrm{H}_{2} \mathrm{O}$ and the respective tridentate ligand (Scheme 3) [49,73]. Ligand protons experience a coordination shift of the ${ }^{1} \mathrm{H}$ NMR resonances upon complexation to a metal centre. In diamagnetic complexes of ddpd and tpy, this effect is strongest for the $\alpha$ protons of the terminal pyridines. These $\alpha$ protons are directed toward the metal ion in a region of electron density of the metal $t_{2 g}$ electrons resulting in additional shielding of the nuclear spin and a corresponding upfield shift. This effect is strong in low-spin $\mathrm{d}^{6}-\left[\mathrm{Co}^{\mathrm{III}}(\mathrm{L})_{2}\right]^{3+}$ and $\mathrm{d}^{6}-\left[\mathrm{Fe}^{\mathrm{II}}(\mathrm{L})_{2}\right]^{2+}$ complexes but less pronounced in the $\mathrm{d}^{10}-\left[\mathrm{Zn} \mathrm{n}^{\mathrm{II}}(\mathrm{L})_{2}\right]^{2+}$ complexes $(\mathrm{L}=\mathrm{ddpd}$, tpy; Table 3$)$. In both diamagnetic series of complexes ( $\left.\mathrm{L}=\mathrm{ddpd}, \mathrm{tpy} ; \mathrm{M}=\mathrm{Zn}^{\mathrm{II}}, \mathrm{Co}^{\mathrm{III}}, \mathrm{Fe}^{\mathrm{II}}\right)$, the coordination shift correlates roughly with the $\mathrm{M} \cdots \mathrm{H}^{\alpha}$ distances estimated from single crystal X-ray diffraction (Table 3). Furthermore, the $\alpha$ protons experience the ring current of pyridines of the second tridentate ligand with $\mathrm{H}^{\cdots}$ (pyridine centre) distances of around $3.2 \AA$ (tpy) and 3.3-3.4 (ddpd). This effect could account for the slightly less pronounced coordination shift in the ddpd complexes (Table 3).

Table 3. Coordination shift $\Delta \delta=\delta$ (complex) $-\delta$ (ligand) of ${ }^{1} \mathrm{H}$ NMR resonances of $\mathrm{H}^{\alpha}$ in diamagnetic $\left[\mathrm{M}(\mathrm{L})_{2}\right]^{n+}$ complexes $\left(\mathrm{L}=\mathrm{ddpd}\right.$, tpy; $\left.\mathrm{M}=\mathrm{Zn}^{\mathrm{II}}, \mathrm{Co}^{\mathrm{III}}, \mathrm{Fe}^{\mathrm{II}}\right)$.

\begin{tabular}{|c|c|c|c|c|}
\hline & \multicolumn{2}{|c|}{$L=\operatorname{ddpd}$} & \multicolumn{2}{|c|}{$L=t p y$} \\
\hline $\mathbf{M}$ & $\Delta \delta\left(\mathrm{H}^{\alpha}\right) / \mathrm{ppm}^{[\mathrm{a}]}$ & $M \cdots H^{\alpha}$ from XRD/Å & $\Delta \delta\left(\mathbf{H}^{\alpha}\right) / \mathrm{ppm}^{[\mathrm{b}]}$ & $\mathbf{M}^{\cdots} \mathbf{H}^{\alpha}$ from XRD/A \\
\hline $\mathrm{Zn}$ & $-0.56[49]$ & 3.06 [49] & $-0.95[74]$ & $3.18-3.28^{[\mathrm{d}]}$ \\
\hline $\mathrm{Co}^{\mathrm{III}}$ & $-1.39[62]$ & $2.92-2.94[\mathrm{c}]$ & $-1.46[68]$ & $3.07[\mathrm{e}]$ \\
\hline $\mathrm{Fe}^{\mathrm{II}}$ & $-1.21[64]$ & $2.99[64]$ & $-1.33^{[\mathrm{f}]}$ & $3.01-3.12[\mathrm{~g}]$ \\
\hline
\end{tabular}

[a] Relative to $\delta\left(\mathrm{H}^{\alpha}(\mathrm{ddpd})\right)=8.29 \mathrm{ppm}\left(\mathrm{CD}_{3} \mathrm{CN}\right)[35]$. ${ }^{[\mathrm{b}]}$ Relative to $\delta\left(\mathrm{H}^{\alpha}(\mathrm{tpy})\right)=8.69 \mathrm{ppm}\left(\mathrm{CDCl}_{3}\right)$ [75]. ${ }^{[\mathrm{cc}}$ This work. ${ }^{[\mathrm{d}]}$ from $\left[\mathrm{Zn}\left(4^{\prime} \text {-thienyl-tpy }\right)_{2}\right]\left[\mathrm{ClO}_{4}\right]_{2}$ complexes [73]. ${ }^{\text {ee] }}$ from $\left[\mathrm{Co}\left(4^{\prime}-p \text {-Tol-tpy }\right)_{2}\right]\left[\mathrm{PF}_{6}\right]_{3}[24] .{ }^{[\mathrm{f}]}\left[\mathrm{Fe}(\mathrm{tpy})_{2}\right] \mathrm{Br}_{2}$ in $\mathrm{D}_{2} \mathrm{O}[76]$. [g] from three different $\left[\mathrm{Fe}\left(4^{\prime}-\mathrm{R}-\mathrm{tpy}\right)_{2}\right]\left[\mathrm{PF}_{6}\right]_{2}$ complexes [77]. 
The $\left[\mathrm{Zn}(\mathrm{tpy})_{2}\right]^{2+}$ complex can be reversibly reduced twice at the tpy ligands (Table 4) [20]. In contrast, $\left[\mathrm{Zn}(\mathrm{ddpd})_{2}\right]^{2+}$ is only irreversibly reduced analogous to the ddpd ligand itself (Table 4). Due to the positive charge of the complex, these potentials are less negative than in the non-coordinated ddpd or tpy ligands (Table 4). Oxidation of the ddpd ligands in $\left[\mathrm{Zn}(\mathrm{ddpd})_{2}\right]^{2+}$ is shifted anodically, as compared to ddpd due to its positive charge (Table 4) [49].

Table 4. Electrochemical data of $\left[\mathrm{M}(\mathrm{L})_{2}\right]^{n+}$ complexes $\left(\mathrm{L}=\mathrm{ddpd}\right.$, tpy; $\mathrm{M}=\mathrm{Zn}^{\mathrm{II}}, \mathrm{Cu}^{\mathrm{II}}, \mathrm{Ni}^{\mathrm{II}}, \mathrm{Co}^{\mathrm{II}}, \mathrm{Fe}^{\mathrm{II}}$, $\left.\mathrm{Mn}^{\mathrm{II}}, \mathrm{Cr}{ }^{\mathrm{III}}, \mathrm{V}^{\mathrm{II}}\right)$ in $\mathrm{V}$ vs. ferrocene/ferrocenium in $\mathrm{CH}_{3} \mathrm{CN}$.

\begin{tabular}{|c|c|c|c|c|}
\hline \multirow[b]{2}{*}{$\mathbf{M}$} & \multicolumn{2}{|c|}{$\mathrm{L}=\mathrm{ddpd}$} & \multicolumn{2}{|c|}{$L=t p y$} \\
\hline & $\begin{array}{l}\text { Oxidation } \\
\text { Processes }\end{array}$ & Reduction Processes & $\begin{array}{l}\text { Oxidation } \\
\text { Processes }\end{array}$ & Reduction Processes \\
\hline L only & $\begin{array}{l}+0.55 \text { (irrev.) } \\
+1.06 \text { (irrev.) [a] }\end{array}$ & -3.27 (irrev.) ${ }^{[a]}$ & not reported & -2.55 (rev.) ${ }^{[\mathrm{b}]}$ \\
\hline $\mathrm{Zn}^{\mathrm{II}}$ & $\begin{array}{l}+1.17 \text {, (irrev.), } \\
+1.34 \text {, (irrev.), } \\
+1.67 \text { (irrev.) [a] }\end{array}$ & -2.38 (irrev.) ${ }^{[a]}$ & not reported & $-1.68,-1.81$ (rev.) ${ }^{[c]}$ \\
\hline $\mathrm{Cu}^{\mathrm{II}}$ & $\begin{array}{l}+0.95 \text { (irrev.), } \\
+1.53 \text { (irrev.), } \\
+1.75 \text { (irrev.), } \\
+2.26 \text { (irrev.) [d] }\end{array}$ & $\begin{array}{c}\left.-0.91 \text { (qrev. } \mathrm{Cu}^{\mathrm{II}} / \mathrm{Cu}^{\mathrm{I}}\right) \\
-3.10 \text { (irrev.) }\end{array}$ & not reported & $\left.-0.79 \underset{[\mathrm{e}]}{(\text { irrev. }} \mathrm{Cu}^{\mathrm{II}} / \mathrm{Cu}^{\mathrm{I}}\right)$ \\
\hline $\mathrm{Ni}^{\mathrm{II}}$ & $\begin{array}{l}+1.22 \text { (qrev.) } \\
+1.71 \text { (irrev.) }\end{array}$ & -2.03 (irrev.) ${ }^{[\mathrm{f}]}$ & +1.29 (qrev.) ${ }^{[g]}$ & $\begin{array}{l}-1.62 \text { (qrev.) }^{[\mathrm{g}]} \\
-1.62 \text { (qrev.) } \\
-1.88 \text { (qrev.) }^{\text {[c] }}\end{array}$ \\
\hline $\mathrm{Co}^{\mathrm{II}}$ & -0.17 (rev.) ${ }^{[\mathrm{h}]}$ & -1.80 (irrev.) $^{[\mathrm{h}]}$ & -0.11 (rev.) ${ }^{[\mathrm{i}]}$ & $\begin{array}{c}-1.16 \text { (rev.) }^{[\mathrm{i}]} \\
-1.17 \text { (rev.), } \\
-2.03 \text { (qrev.) }^{[\mathrm{c}]}\end{array}$ \\
\hline $\mathrm{Fe}^{\mathrm{II}}$ & $\begin{aligned} & +0.33 \text { (rev.) } \\
+1.63 \text { (irrev.) } & \text { [j] }\end{aligned}$ & -2.33 (irrev.) ${ }^{[j]}$ & +0.71 (rev.) ${ }^{[\mathrm{k}]}$ & $\begin{array}{l}-1.64 \text { (rev.) } \\
-1.80 \text { (rev.) }\end{array}$ \\
\hline $\mathrm{Mn}^{\mathrm{II}}$ & - & - & +0.86 (rev.) ${ }^{[1]}$ & $\begin{array}{c}-1.52 \text { (rev.), } \\
-1.86 \text { (rev.), } \\
-2.37 \text { (rev.) }{ }^{11]}\end{array}$ \\
\hline $\mathrm{Cr}^{\mathrm{III}}$ & +1.71 (irrev.) $[\mathrm{m}]$ & $\begin{array}{c}\left.-1.11 \text { (rev. } \mathrm{Cr}^{\mathrm{III}} / \mathrm{Cr}^{\mathrm{II}}\right) \\
-1.94 \text { (irrev.) }\end{array}$ & not reported & $\begin{array}{l}-0.53 \text { (rev.) } \\
-0.95 \text { (rev.) }\end{array}$ \\
\hline $\mathrm{V}^{\mathrm{II}}$ & - & - & -0.09 (qrev.) ${ }^{[o]}$ & $\begin{array}{c}-1.25 \text { (rev.) } \\
-1.40 \text { (rev.) } \\
-1.93 \text { (rev.) }{ }^{[o]}\end{array}$ \\
\hline
\end{tabular}

In the solid state, the coordination geometry of $\left[\mathrm{Zn}(\mathrm{ddpd})_{2}\right]^{2+}$ deviates appreciably from an idealized octahedron with $S(\mathrm{OC}-6)=1.18$ when compared to other $\left[\mathrm{M}(\mathrm{ddpd})_{2}\right]^{n+}$ complexes (Figure 3a, Table 1). However, the distortion of $\left[\mathrm{Zn}(\operatorname{tpy})_{2}\right]^{2+}$ is dramatically larger with $S(\mathrm{OC}-6)=4.45$, which can be accounted for by the very small N-Zn-N bite angles of $75^{\circ}$ (Table 2). 


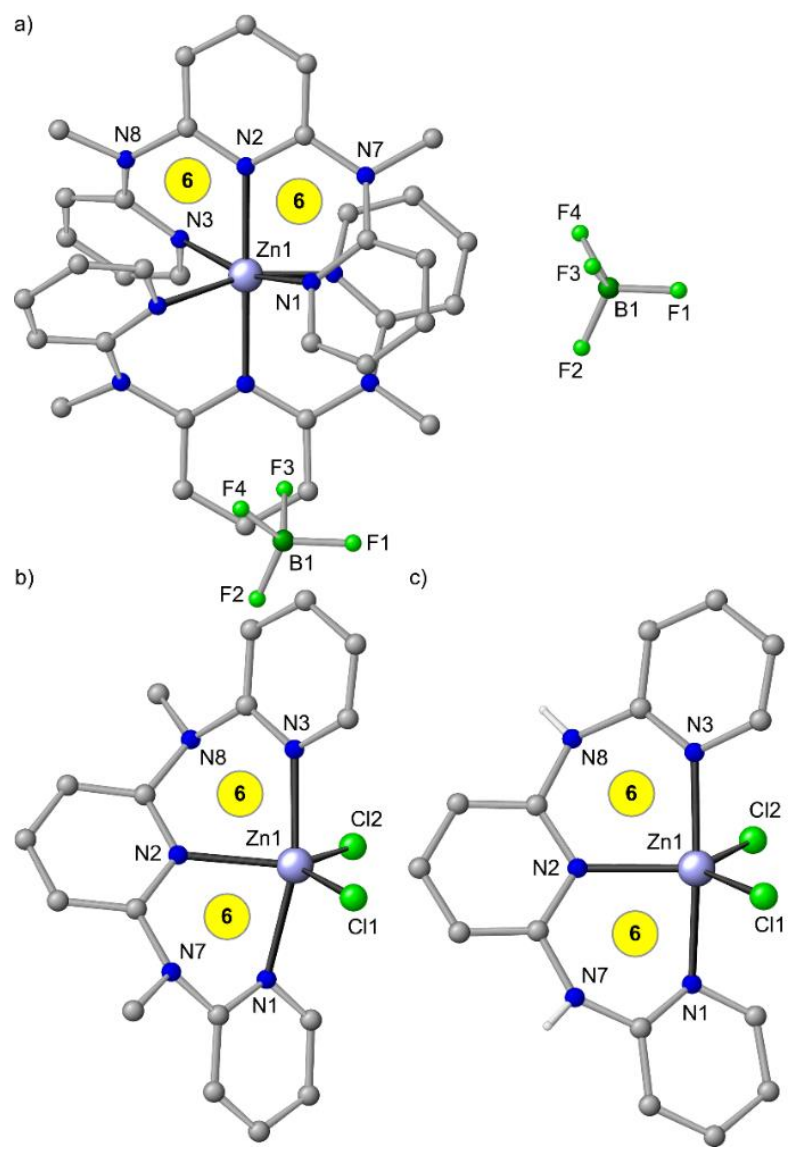

Figure 3. (a) Molecular structures of mer-[Zn(ddpd) $\left.)_{2}\right]\left[\mathrm{BF}_{4}\right]_{2}[49]$, (b) $\mathrm{ZnCl}_{2}(\mathrm{ddpd})$ from the mer-[Zn(ddpd $\left.)_{2}\right]$ [ $\left.\mathrm{ZnCl}_{4}\right] / \mathrm{Zn}(\mathrm{ddpd}) \mathrm{Cl}_{2}$ co-crystal [49] and (c) $\mathrm{ZnCl}_{2}\left(\mathrm{H}_{2}\right.$ tpda) [41] in the solid state. Carbon-bound hydrogen atoms and solvent molecules omitted. Atom numbering unified for clarity. Chelate ring sizes highlighted in yellow.

Coordination of $\mathrm{Zn}^{2+}$ to ddpd shifts the $\pi-\pi^{*}$ absorption maxima to higher energy from $274 / 333 \mathrm{~nm}$ to $248 / 308 \mathrm{~nm}$. In the colourless homoleptic complex, these bands are assigned to ligand-centred transitions essentially from the electron-rich N-Me groups to the pyridine's $\pi^{*}$ orbitals. Fluorescence is observed at $373 \mathrm{~nm}$ in (acid-free) $\mathrm{CH}_{2} \mathrm{Cl}_{2}$ with $6.5 \%$ quantum yield and $0.6 \mathrm{~ns}$ lifetime [49]. The diminished fluorescence lifetime as compared to ddpd is likely due to the heavy-atom effect of $\mathrm{Zn}^{2+}$, enabling intersystem crossing (ISC) to the triplet state. The tpy-based fluorescence of $\left[\mathrm{Zn}(\mathrm{tpy})_{2}\right]^{2+}$ is found at higher energy with significantly higher quantum yield $\left(\lambda_{\mathrm{em}}=353 \mathrm{~nm}\right.$, $\Phi=65 \%$ ) [81]. The N-Me donor groups of ddpd are likely responsible for the slightly lower emission energy of $\left[\mathrm{Zn}(\mathrm{ddpd})_{2}\right]^{2+}$. The flexibility of the six-membered chelates possibly allow for enhanced non-radiative relaxation in $\left[\mathrm{Zn}(\mathrm{ddpd})_{2}\right]^{2+}$.

With coordinating counter ions such as chloride present, heteroleptic complexes form. $\mathrm{ZnCl}_{2}$ and terpyridine yield the neutral complex $\mathrm{ZnCl}_{2}$ (tpy) [82]. With ddpd and $\mathrm{ZnCl}_{2}$ an equilibrium between $\left[\mathrm{Zn}(\mathrm{ddpd})_{2}\right]\left[\mathrm{ZnCl}_{4}\right]$ and $\mathrm{Zn}(\mathrm{ddpd}) \mathrm{Cl}_{2}$ is established with a 1:1.8 ratio in $\mathrm{CD}_{3} \mathrm{CN}$ solution at room temperature according to ${ }^{1} \mathrm{H}$ NMR spectroscopy. From this mixture, co-crystals of $\left[\mathrm{Zn}(\mathrm{ddpd})_{2}\right]\left[\mathrm{ZnCl}_{4}\right] / \mathrm{Zn}(\mathrm{ddpd}) \mathrm{Cl}_{2}$ with the complexes in a 1:1 ratio are obtained (Figure 3b) [49]. These findings clearly underscore that the $\mathrm{d}^{10}$ ion zinc(II) is labile and very flexible with respect to coordination numbers (4-6) and geometries (tetrahedral, trigonal-bipyramidal, octahedral). From the $\mathrm{CH}_{3} \mathrm{CN}$ solution of the equilibrating $\left[\mathrm{Zn}(\mathrm{ddpd})_{2}\right]\left[\mathrm{ZnCl}_{4}\right] / \mathrm{Zn}(\mathrm{ddpd}) \mathrm{Cl}_{2}$ mixture, only the emission of the $\left[\mathrm{Zn}(\mathrm{ddpd})_{2}\right]^{2+}$ ion is observed and $\mathrm{Zn}(\mathrm{ddpd}) \mathrm{Cl}_{2}$ appears to be essentially non-emissive. 
Interestingly, the analogous five-coordinate complex $\mathrm{Zn}\left(\mathrm{H}_{2} \mathrm{tpda}\right) \mathrm{Cl}_{2}$ has been reported (Figure $3 \mathrm{c}$ ) with a fluorescence emission band peaking at $392 \mathrm{~nm}$ in $\mathrm{MeOH}$ [41]. The reported UV/Vis absorption spectrum of $\mathrm{Zn}\left(\mathrm{H}_{2}\right.$ tpda $) \mathrm{Cl}_{2}$ in $\mathrm{MeOH}$ with a strong $311 \mathrm{~nm}$ absorption band [41], however, strongly resembles that of $\left[\mathrm{Zn}(\mathrm{ddpd})_{2}\right]^{2+}$ ions [49]. Hence, an analogous equilibrium $\left[\mathrm{Zn}\left(\mathrm{H}_{2} \mathrm{tpda}\right)_{2}\right]\left[\mathrm{ZnCl}_{4}\right] / \mathrm{Zn}\left(\mathrm{H}_{2} \mathrm{tpda}\right) \mathrm{Cl}_{2}$ might be present under these conditions as well and the observed fluorescence might be better assigned to the $\left[\mathrm{Zn}\left(\mathrm{H}_{2} \mathrm{tpda}\right)_{2}\right]^{2+}$ ion instead to that of the mixed-ligand $\mathrm{Zn}\left(\mathrm{H}_{2}\right.$ tpda $) \mathrm{Cl}_{2}$ complex. No photophysical data are reported for $\mathrm{ZnCl}_{2}$ (tpy) and consequently a comparison with $\mathrm{Zn}(\mathrm{ddpd}) \mathrm{Cl}_{2}$ and $\mathrm{Zn}\left(\mathrm{H}_{2} \mathrm{tpda}\right) \mathrm{Cl}_{2}$ is unfeasible.

The diamagnetic $\mathrm{d}^{10}-\left[\mathrm{ZnL}_{2}\right]^{2+}$ complexes with $\mathrm{L}=\mathrm{ddpd}$ and tpy are distorted, substitutionally labile, optically transparent in the visible spectral region and fluoresce only in the UV spectral region. The tpy complex shows reversible ligand-centred reductions, while the ddpd complex is basically redox-inert between $-2.3 \mathrm{~V}$ and $+1.1 \mathrm{~V}$.

\section{4. $m e r-\left[\mathrm{Cu}(\mathrm{ddpd})_{2}\right]^{2+}\left[\mathrm{d}^{9}\right]$}

The green and dark green $\mathrm{d}^{9}$-copper(II) complexes $\left[\mathrm{Cu}(\mathrm{ddpd})_{2}\right]^{2+}$ and $\left[\mathrm{Cu}(\mathrm{tpy})_{2}\right]^{2+}$ are $S=1 / 2$ paramagnets (Table 5). As expected for copper(II) ions, the spin-only value of $\chi \mathrm{T}=0.375 \mathrm{~cm}^{3} \mathrm{~K}$ $\mathrm{mol}^{-1}$ is clearly surpassed [83]. Both copper(II) complexes can be reduced to copper(I) species. However, this process is quasireversible for $\left[\mathrm{Cu}(\mathrm{ddpd})_{2}\right]^{2+}$ and irreversible for $\left[\mathrm{Cu}(\mathrm{tpy})_{2}\right]^{2+}$ at room temperature (Table 4). This behaviour suggests a reduction of the coordination number in both cases [12]. This phenomenon had been elegantly exploited by Sauvage and co-workers in the design of redox-controlled motions in catenates using redox-active $[\mathrm{Cu}(\mathrm{tpy})]^{2+/+}$ units [12-14]. Further irreversible oxidations and reductions are similar to the ones observed for $\left[\mathrm{Zn}(\mathrm{ddpd})_{2}\right]^{2+}$ and assigned to ddpd-centred processes (Table 4).

Table 5. Room temperature magnetic susceptibility and $g_{\text {iso }}$ data (from SQUID or EPR measurements) of open-shell $\left[\mathrm{M}(\mathrm{ddpd})_{2}\right]^{n+}$ and $\left[\mathrm{M}\left(\mathrm{tpy}_{2}\right)_{2}\right]^{n+}$ complexes $\left(\mathrm{M}=\mathrm{Cu}^{\mathrm{II}}, \mathrm{Ni}^{\mathrm{II}}, \mathrm{Co}^{\mathrm{II}}, \mathrm{Mn}^{\mathrm{II}}, \mathrm{Mn}^{\mathrm{III}}, \mathrm{Cr}^{\mathrm{II}}, \mathrm{Cr}^{\mathrm{III}}, \mathrm{V}^{\mathrm{II}}\right)$.

\begin{tabular}{|c|c|c|c|c|c|}
\hline \multirow[b]{2}{*}{$\mathbf{M}$} & \multicolumn{2}{|c|}{$L=$ ddpd } & \multicolumn{2}{|c|}{$L=t p y$} & \multirow{2}{*}{$\begin{array}{c}\left.\text { Spin-Only Value }{ }^{[\mathrm{a}}\right] \\
\chi \mathrm{T} / \mathrm{cm}^{3} \mathrm{~K} \mathrm{~mol}^{-1}\end{array}$} \\
\hline & $\chi \mathrm{T} / \mathrm{cm}^{3} \mathrm{~K} \mathrm{~mol}^{-1}$ & $g_{\text {iso }}$ & $\chi \mathrm{T} / \mathrm{cm}^{3} \mathrm{~K} \mathrm{~mol}^{-1}$ & $g_{\text {iso }}$ & \\
\hline $\mathrm{Cu}^{\mathrm{II}}$ & $0.443^{[\mathrm{b}]}$ & 2.122 (EPR) ${ }^{[b]}$ & $0.475^{[c]}$ & 2.135 (EPR) [d] & 0.375 \\
\hline $\mathrm{Ni}^{\mathrm{II}}$ & $1.11^{[\mathrm{e}]}$ & $2.12($ from $\chi \mathrm{T})[\mathrm{e}]$ & $1.20^{[\mathrm{f}]}$ & $2.19($ from $\chi \mathrm{T})[\mathrm{f}]$ & 1.000 \\
\hline $\mathrm{Co}^{\mathrm{II}}$ & $2.53[\mathrm{~g}]$ & $2.32($ from $\chi \mathrm{T})$ [g] & $2.31-3.00[\mathrm{~h}]$ & $2.22-2.58($ from $\chi \mathrm{T}){ }^{[\mathrm{h}]}$ & 1.875 \\
\hline $\mathrm{Mn}^{\mathrm{II}}$ & - & - & $4.62[\mathrm{i}]$ & - & 4.375 \\
\hline $\mathrm{Mn}^{\mathrm{III}}$ & - & - & $2.68^{[j]}$ & $1.89($ from $\chi \mathrm{T})[\mathrm{j}]$ & 3.000 \\
\hline $\mathrm{Cr}^{\mathrm{II}}$ & 2.67 & $1.89($ from $\chi \mathrm{T})$ & $0.938^{[\mathrm{k}]}$ & $1.94(\text { from } \chi \mathrm{T})^{[\mathrm{k}]}$ & 3.000 \\
\hline $\mathrm{Cr}^{\mathrm{III}}$ & $1.838^{[1]}$ & $1.990(\mathrm{EPR}, 77 \mathrm{~K})^{[1]}$ & $1.921^{[\mathrm{k}]}$ & $1.95(\mathrm{EPR}, 150 \mathrm{~K})^{[\mathrm{m}]}$ & 1.875 \\
\hline $\mathrm{V}^{\mathrm{II}}$ & - & - & $1.721^{[\mathrm{n}]}$ & $1.92($ from $\chi T){ }^{[\mathrm{n}]}$ & 1.875 \\
\hline
\end{tabular}

${ }^{\text {[a] }}$ ref [83]. ${ }^{[b]}$ ref [60]. ${ }^{[c]}$ ref [84]. ${ }^{[d]}$ ref [85]. ${ }^{\text {[e] }}$ ref [61]. ${ }^{[f]}$ for [Ni(tpy) $\left.)_{2}\right] \mathrm{Br}_{2}$ [86]. ${ }^{[g]}$ ref [62]. ${ }^{[\mathrm{h}]}$ for [Co(tpy $\left.)_{2}\right] \mathrm{Cl}_{2}$, $\left[\mathrm{Co}\left(\mathrm{tpy}_{2}\right)_{2}\right] \mathrm{Br}_{2},\left[\mathrm{Co}(\mathrm{tpy})_{2}\right]\left[\mathrm{ClO}_{4}\right]_{2}\left[{ }^{[86]}{ }^{[\mathrm{i}]}\right.$ ref [87]. ${ }^{[j]}$ ref [70]. ${ }^{[\mathrm{k}]}$ This "chromium(II)" complex is correctly described as $\left[\mathrm{Cr}^{\mathrm{III}}\left(\right.\right.$ tpy. $\left.{ }^{-}\right)(\text {tpy) }]^{2+}$ with a $S=1$ ground state requiring $\chi \mathrm{T}$ (spin-only) $=1.000 \mathrm{~cm}^{3} \mathrm{~K} \mathrm{~mol}^{-1}$; ref. [27], similar to $\left[\mathrm{Cr}^{\mathrm{III}}\left(\text { bpy } \cdot^{-}\right)(\mathrm{bpy})_{2}\right]^{2+}$; ref. [88]. ${ }^{[\mathrm{ll}}$ ref [50] and Figure S1. ${ }^{\mathrm{Im}]}$ ref [89]. ${ }^{\mathrm{n}]}$ for $\left[\mathrm{V}(\mathrm{tpy})_{2}\right] \mathrm{I}_{2}[90]$.

$\left[\mathrm{Cu}(\mathrm{ddpd})_{2}\right]^{2+}$ exhibits two ligand field bands at $653 \mathrm{~nm}\left(\varepsilon=25 \mathrm{M}^{-1} \mathrm{~cm}^{-1}\right)$ and $1254 \mathrm{~nm}\left(\varepsilon=5 \mathrm{M}^{-1}\right.$ $\mathrm{cm}^{-1}$ ) in $\mathrm{CH}_{3} \mathrm{CN}$ [60]. The latter band arises from the Jahn-Teller [59] distortion of the $\mathrm{d}^{9}$ complex with $\left(\mathrm{t}_{2 \mathrm{~g}}\right)^{6}\left(\mathrm{e}_{\mathrm{g}}\right)^{3}$ electron configuration and the resulting splitting of the ${ }^{2} \mathrm{E}$ ground state (term symbol based on idealized $O$ symmetry). From the two bands, the ligand field splitting $\Delta_{\mathrm{o}}$ and the Jahn-Teller splitting $4 \delta_{1}$ are estimated as $11,325 \mathrm{~cm}^{-1}$ and $7975 \mathrm{~cm}^{-1}$, respectively [60]. For analogous tpy complexes $\left[\mathrm{Cu}(\text { tpy })_{2}\right]^{2+}$ with varying counter ions, both $\Delta_{\mathrm{o}}\left(11,200-11,300 \mathrm{~cm}^{-1}\right)$ and $4 \delta_{1}\left(5900-6500 \mathrm{~cm}^{-1}\right)$ are smaller [91]. This can be traced back to the stronger $\sigma$ interaction of ddpd with the copper $\mathrm{d}$ orbitals and consequently a slightly larger ligand field splitting and furthermore a significantly larger Jahn-Teller [59] splitting. The larger Jahn-Teller splitting is furthermore favoured by the higher flexibility of ddpd. 
Both copper(II) complexes are fluxional at room temperature. The dynamics slow down at lower temperature. "Freezing-in" occurs below $77 \mathrm{~K}$ for the tpy complex and at $\approx 100 \mathrm{~K}$ for the ddpd complex [60]. This suggests a larger Jahn-Teller barrier for $\left[\mathrm{Cu}(\mathrm{ddpd})_{2}\right]\left[\mathrm{BF}_{4}\right]_{2}$ between the two degenerate Jahn-Teller isomers (Figure $4 \mathrm{~b}$ ). In the solid state at $123 \mathrm{~K}$, the $\left[\mathrm{CuN}_{6}\right]$ coordination sphere of $\left[\mathrm{Cu}(\mathrm{ddpd})_{2}\right]^{2+}$ corresponds to an elongated octahedron with the $\mathrm{Cu}-\mathrm{N} 2 / \mathrm{N} 5$ distances $(1.989 / 2.060 \AA)$ fixed due to the chelate ligand, short $\mathrm{Cu}-\mathrm{N} 1 / \mathrm{N} 3(2.0256 / 2.0256 \AA)$ and long $\mathrm{Cu}-\mathrm{N} 4 / \mathrm{N} 6$ distances $(2.3318 / 2.3318 \AA$ ) [60]. At $263 \mathrm{~K}$, the two possible elongated octahedrons (along $\mathrm{x}$ and along $\mathrm{y}$ ) are dynamically averaged with fixed $\mathrm{Cu}-\mathrm{N} 2 / \mathrm{N} 5$ distances $(2.064 / 1.979 \AA)$ along z and averaged $\mathrm{Cu}-\mathrm{N} 1 / \mathrm{N} 3(2.149 / 2.149 \AA)$ and $\mathrm{Cu}-\mathrm{N} 4 / \mathrm{N} 6$ distances $(2.191 / 2.191 \AA)$ [60]. The combined action of dynamic Jahn-Teller distortion $(x / y)$ and ligand strain $(\mathrm{Cu}-\mathrm{N} 2 / \mathrm{N} 5$ fixed along $\mathrm{z})$ results in an apparent compressed octahedron. This apparent change from elongated to compressed octahedral upon warming is easily followed in the temperature dependent $X$-band EPR spectra of $\left[\mathrm{Cu}(\mathrm{ddpd})_{2}\right]\left[\mathrm{BF}_{4}\right]_{2}$ (powder), $\left[\mathrm{Cu}_{0.875} \mathrm{Fe}_{0.125}(\mathrm{ddpd})_{2}\right]\left[\mathrm{BF}_{4}\right]_{2}$ (powder) (Figure 4) or $\left[\mathrm{Cu}(\mathrm{ddpd})_{2}\right]\left[\mathrm{BF}_{4}\right]_{2}$ (dissolved in water/glycerol) [60]. For example, copper(II) doped into the diamagnetic $\left[\mathrm{Fe}^{\mathrm{II}}(\mathrm{ddpd})_{2}\right]\left[\mathrm{BF}_{4}\right]_{2}$ host (see Section 7) gives $g_{x}=2.228, g_{y}=g_{z}=2.063$ and $A_{x}\left({ }^{63 / 65} \mathrm{Cu}\right)=146 \mathrm{G}$ at $103 \mathrm{~K}$, indicating an axially elongated octahedron. At $293 \mathrm{~K}, g_{x}=g_{y}=2.156, g_{z}=2.058$ and $A_{x}=A_{y}\left({ }^{63 / 65} \mathrm{Cu}\right)=79 \mathrm{G}$ are found, suggesting an axially compressed octahedron (Figure 4). In the intermediate temperature range, the EPR spectra are weighted superpositions of the low- and high-temperature spectra [60]. As this temperature-dependent dynamic is essentially independent of the environment (pure copper(II) crystal, diamagnetic host crystal, frozen solution), cooperative effects are absent and the Jahn-Teller barrier is an intrinsic feature of the $\left[\mathrm{Cu}(\mathrm{ddpd})_{2}\right]^{2+}$ cation.

Compared to $\left[\mathrm{Cu}(\text { tpy })_{2}\right]^{2+},\left[\mathrm{Cu}(\mathrm{ddpd})_{2}\right]^{2+}$ is more difficult to reduce to copper(I), features a larger ligand field and Jahn-Teller splitting and a higher barrier for the Jahn-Teller dynamics. All these phenomena can be accounted for by the stronger $\sigma$-donating character of ddpd.
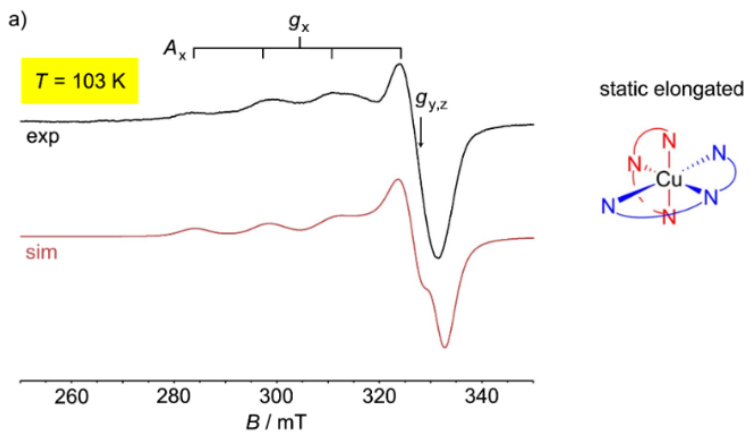

b)
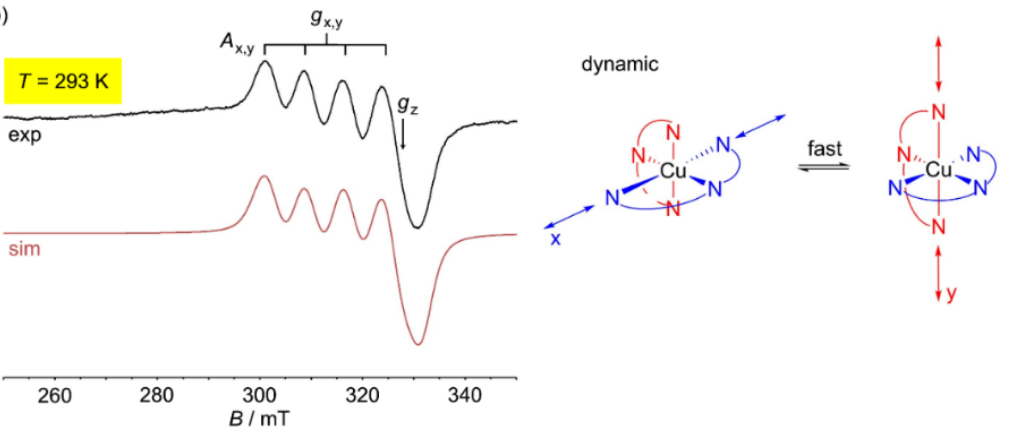

Figure 4. (a) X-band powder EPR spectrum of $\left[\mathrm{Cu}_{0.875} \mathrm{Fe}_{0.125}(\mathrm{ddpd})_{2}\right]\left[\mathrm{BF}_{4}\right]_{2}$ at $103 \mathrm{~K}$, simulation in red and illustration of the static elongated octahedron. (b) X-band powder EPR spectrum of $\left[\mathrm{Cu}_{0.875} \mathrm{Fe}_{0.125}(\mathrm{ddpd})_{2}\right]\left[\mathrm{BF}_{4}\right]_{2}$ at $293 \mathrm{~K}$, simulation in red and illustration of the dynamically elongated octahedrons [60]. 


\section{5. $m e r-\left[\mathrm{Ni}(\mathrm{ddpd})_{2}\right]^{2+}\left[\mathrm{d}^{8}\right]$}

The d electron configuration of nickel(II) in an octahedral ligand field is $\left(t_{2 g}\right)^{6}\left(e_{g}\right)^{2}$, leading to a ${ }^{3} \mathrm{~A}_{2}$ ground state. The magnetic susceptibility data of $\chi \mathrm{T}=1.20$ and $1.11 \mathrm{~cm}^{3} \mathrm{~K} \mathrm{~mol}^{-1}$ for $\left[\mathrm{Ni}(\mathrm{tpy})_{2}\right]^{2+}$ and $\left[\mathrm{Ni}(\mathrm{ddpd})_{2}\right]^{2+}$ confirm the triplet ground states (Table 5). At low temperature, zero-field splitting is apparent leading to a drop of the $\chi \mathrm{T}$ values in both complexes [61,92]. The ligand-dictated octahedral compression of $\left[\mathrm{Ni}(\text { tpy })_{2}\right]^{2+}$ is much more pronounced $(S(\mathrm{OC}-6)=3.18 ; d(\mathrm{Ni}-\mathrm{N} 2) / d(\mathrm{Ni}-\mathrm{N} 1)=0.94)$ than that of $\left[\mathrm{Ni}(\mathrm{ddpd})_{2}\right]^{2+}(S(\mathrm{OC}-6)=0.60 ; d(\mathrm{Ni}-\mathrm{N} 2) / d(\mathrm{Ni}-\mathrm{N} 1)=0.98)($ Tables 1 and 2$)$.

The UV/Vis/NIR absorption spectra of red $\left[\mathrm{Ni}(\text { tpy })_{2}\right]^{2+}$ and pink $\left[\mathrm{Ni}(\mathrm{ddpd})_{2}\right]^{2+}$ are dominated by the two spin-allowed ${ }^{3} \mathrm{~A}_{2} \rightarrow{ }^{3} \mathrm{~T}_{1}$ and ${ }^{3} \mathrm{~A}_{2} \rightarrow{ }^{3} \mathrm{~T}_{2}$ ligand field transitions at $18,500 / 12,350$ and $19,200 / 12,700 \mathrm{~cm}^{-1}$, respectively (Figure 5) [24,61,91]. The transitions at lowest energy correspond directly to the respective ligand field splittings $\Delta_{\mathrm{o}}=12,350$ and $12,700 \mathrm{~cm}^{-1}$, demonstrating that ddpd induces a stronger ligand field by $350 \mathrm{~cm}^{-1}$. Nickel(II) polypyridine complexes display the spin-forbidden ${ }^{3} \mathrm{~A}_{2} \rightarrow{ }^{1} \mathrm{E}$ transition close to the low-energy spin-allowed ${ }^{3} \mathrm{~A}_{2} \rightarrow{ }^{3} \mathrm{~T}_{2}$ transition indicating a comparably strong ligand field in all cases. The intensity of the spin-flip band is rather high due to an intensity borrowing mechanism, which scales directly with the square of the spin-orbit coupling parameter $\lambda$ and inversely with the square of the energy difference $\Delta E$ (Figure 5; shoulder at $11,300 \mathrm{~cm}^{-1}$ for $\left[\mathrm{Ni}(\mathrm{ddpd})_{2}\right]^{2+}$ ) [93]. The energy differences between the ${ }^{1} \mathrm{E}$ and ${ }^{3} \mathrm{~T}_{2}$ spectroscopic terms are quite small and consequently luminescence from the spin-flip ${ }^{1} \mathrm{E}$ states is not observed [61].

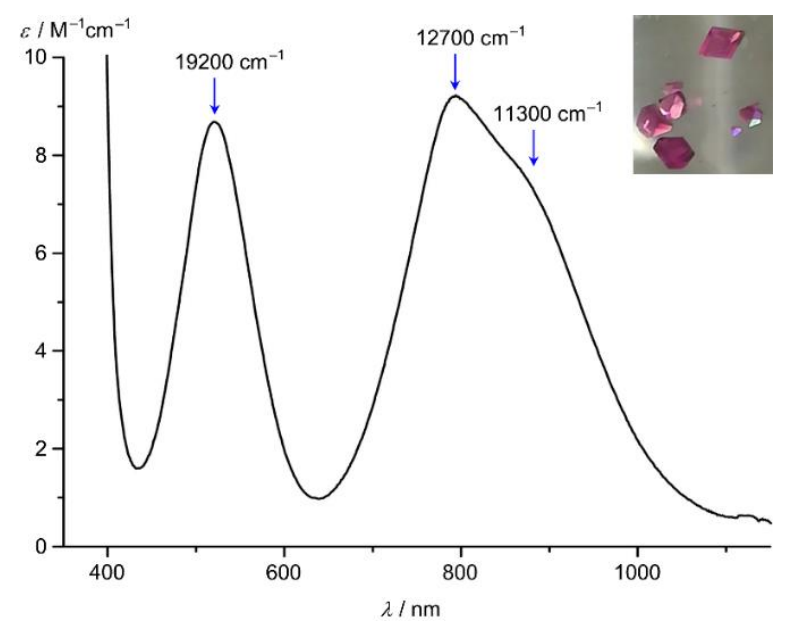

Figure 5. UV/Vis/NIR spectrum of $\left[\mathrm{Ni}(\mathrm{ddpd})_{2}\right]\left[\mathrm{BF}_{4}\right]_{2}$ in $\mathrm{CH}_{3} \mathrm{CN}$; ligand field bands and the spin-flip band indicated by blue arrows; photograph of crystals of $\left[\mathrm{Ni}(\mathrm{ddpd})_{2}\right]\left[\mathrm{BF}_{4}\right]_{2}[61]$.

Reduction of $\left[\mathrm{Ni}\left(\mathrm{tpy}_{2}\right]_{2}\right]^{2+}$ is ligand-based yielding $\left[\mathrm{Ni}^{\mathrm{II}}(\text { tpy })\left(\text { tpy } \cdot^{-}\right)\right]^{+}$, which slowly releases a tpy ligand $[20,94]$. The resulting proposed $\left[\mathrm{Ni}^{\mathrm{II}}\left(\mathrm{tpy} \cdot \cdot^{-}\right)\right]^{+}$species exhibits selectivity for electrochemical $\mathrm{CO}_{2}$ reduction over proton reduction [20]. Oxidation of $\left[\mathrm{Ni}(\mathrm{tpy})_{2}\right]^{2+}$ to nickel(III) has been reported at $1.29 \mathrm{~V}$ [78]. Similarly, a quasireversible oxidation of $\left[\mathrm{Ni}(\mathrm{ddpd})_{2}\right]^{2+}$ to $\left[\mathrm{Ni}(\mathrm{ddpd})_{2}\right]^{3+}$ occurs at $1.22 \mathrm{~V}$ [61]. Reduction of $\left[\mathrm{Ni}(\mathrm{ddpd})_{2}\right]^{2+}$ is irreversible $(-2.03 \mathrm{~V})$. Presumably, the irreversible reduction is associated with the formation of $\left[\mathrm{Ni}^{\mathrm{I}}(\mathrm{ddpd})\right]^{+}$species after ligand loss. In the presence of $\mathrm{CO}_{2}$ /acetic acid a catalytic current with an onset potential of ca. $-1.1 \mathrm{~V}$ versus ferrocene is observed (Figure S2). A detailed comparison of this behaviour and that proposed for $\left[\mathrm{Ni}(\mathrm{tpy})_{2}\right]^{2+}$ will be subject to future studies [20].

In summary, the magnetic, optical and redox properties of $\left[\mathrm{Ni}(\mathrm{ddpd})_{2}\right]^{2+}$ are very similar to those of $\left[\mathrm{Ni}(\mathrm{tpy})_{2}\right]^{2+}$, with the ligand field splitting induced by ddpd being larger by $350 \mathrm{~cm}^{-1}$. 


\section{6. $m e r-\left[\operatorname{Co}(\mathrm{ddpd})_{2}\right]^{2+}, c i s-f a c-\left[\mathrm{Co}(\mathrm{ddpd})_{2}\right]^{2+}\left[\mathrm{d}^{7}\right]$ and $m e r-\left[\mathrm{Co}(\mathrm{ddpd})_{2}\right]^{3+}\left[\mathrm{d}^{6}\right]$}

Reaction of $\mathrm{Co}\left(\mathrm{BF}_{4}\right)_{2} \times 6 \mathrm{H}_{2} \mathrm{O}$ with ddpd in ethanol (Scheme 3) yields a precipitate, which contains two phases according to powder $\mathrm{X}$-ray diffraction and SEM images [63]. Paramagnetic NMR spectroscopy in acetonitrile solution indicates the presence of only a single metal complex isomer [63]. Re-crystallization from $\mathrm{CH}_{3} \mathrm{CN}$ yields crystals of mer-[Co(ddpd) $\left.)_{2}\right]\left[\mathrm{BF}_{4}\right]_{2} \times 2 \mathrm{CH}_{3} \mathrm{CN}$ (Figure 6a) [62]. The initial precipitate contains a further microcrystalline phase in addition to crystals of mer-[Co(ddpd $\left.)_{2}\right]\left[\mathrm{BF}_{4}\right]_{2} \times 2 \mathrm{CH}_{3} \mathrm{CN}$. With the aid of electron diffraction tomography, these crystals are identified as cis-fac-[Co(ddpd $\left.)_{2}\right]\left[\mathrm{BF}_{4}\right]_{2}$ with the ddpd ligand coordinating in a facial tripodal manner (Figure 6b) [63]. In both stereoisomers, the cobalt(II) centres are in their high-spin state [63]. The cis-fac isomer is the kinetic product, while the mer isomer is the thermodynamically stable one. In contrast, only the mer isomers of $\left[\mathrm{Co}(\text { tpy })_{2}\right]^{2+}$ are available due to the rigid nature of tpy.

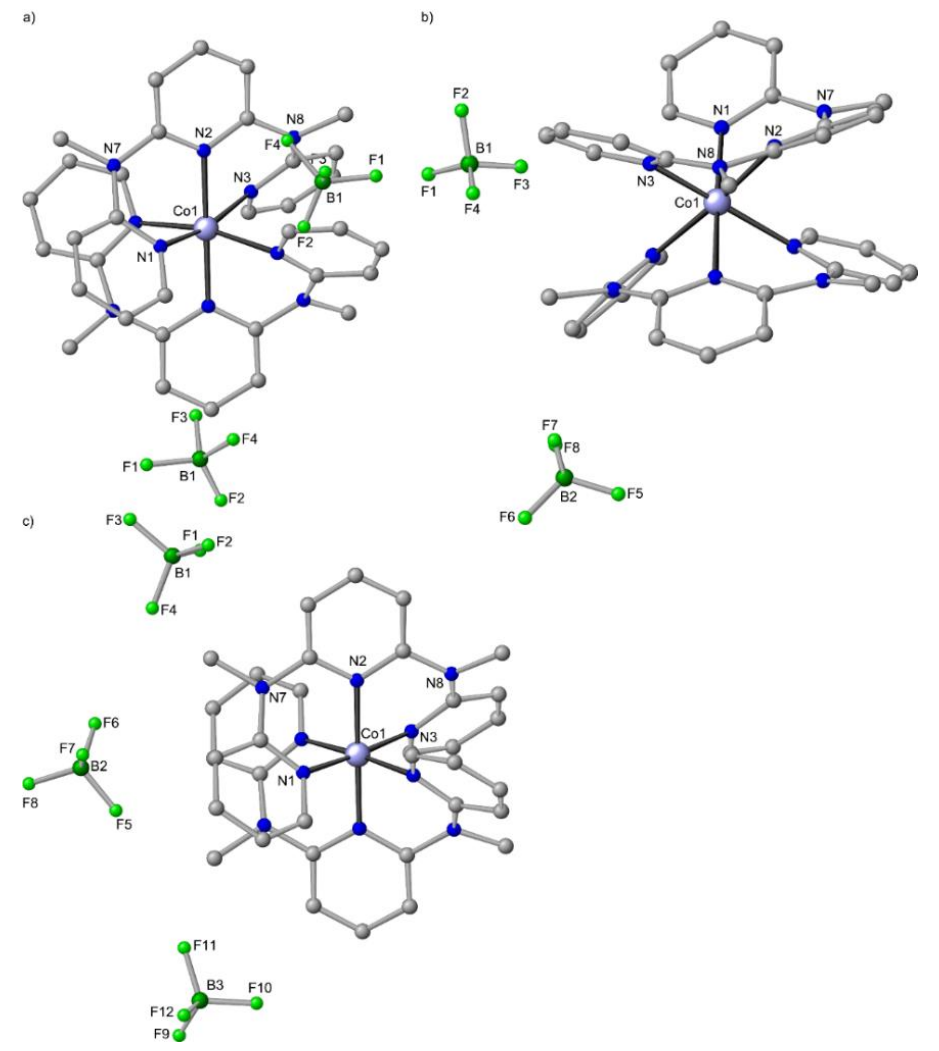

Figure 6. Molecular structures of (a) mer-[Co(ddpd $\left.)_{2}\right]\left[\mathrm{BF}_{4}\right]_{2} \times 2 \mathrm{CH}_{3} \mathrm{CN}$ [62], (b) cis-fac-[Co(ddpd $\left.)_{2}\right]$ $\left[\mathrm{BF}_{4}\right]_{2}[63]$ and $(\mathrm{c})$ mer- $\left[\mathrm{Co}(\mathrm{ddpd})_{2}\right]\left[\mathrm{BF}_{4}\right]_{3} \times 3 \mathrm{CH}_{3} \mathrm{CN}$ in the solid state; hydrogen atoms and solvent molecules omitted. Atom numbering unified for clarity.

For the $d^{7}$ electron configuration, the ground state can be either low-spin $\left(\left(t_{2 g}\right)^{6}\left(e_{\mathrm{g}}\right)^{1} ;{ }^{2} \mathrm{E}\right.$; $S=1 / 2)$ or high-spin $\left(\left(\mathrm{t}_{2 \mathrm{~g}}\right)^{5}\left(\mathrm{e}_{\mathrm{g}}\right)^{2} ;{ }^{4} \mathrm{~T}_{1} ; S={ }^{3} / 2\right)[15,16]$. In fact, the terpyridine complexes $\left[\mathrm{Co}{ }^{\mathrm{II}}(\text { tpy })_{2}\right] \mathrm{X}_{2} \times n \mathrm{H}_{2} \mathrm{O}\left(\mathrm{X}=\right.$ halide, pseudohalide, $\left.\mathrm{NO}_{3}{ }^{-}, \mathrm{ClO}_{4}{ }^{-} ; n=0-5\right)$ exhibit incomplete and gradual SCO behaviour $[95,96]$. On the other hand, $\left[\mathrm{Co}(\mathrm{tpy})_{2}\right]\left[\mathrm{PF}_{6}\right]_{2}$ remains in the high-spin state down to low temperatures [16]. The entropy change during the SCO due to the spin change amounts to $\Delta S_{\text {spin }}=R\left[\ln (2 S+1)_{\mathrm{hs}}-\ln (2 S+1)_{\mathrm{ls}}\right]=5.8 \mathrm{~J} \mathrm{~K}^{-1} \mathrm{~mol}^{-1}$. The $\Delta S_{\text {spin }}$ of cobalt(II) is smaller than those of $\mathrm{d}^{6}$-iron(II) (13.4 $\left.\mathrm{J} \mathrm{K}^{-1} \mathrm{~mol}^{-1}\right)$ or $\mathrm{d}^{5}$-iron(III) $\left(9.1 \mathrm{~J} \mathrm{~K}^{-1} \mathrm{~mol}^{-1}\right) \mathrm{SCO}$ complexes. Therefore, the SCO phenomenon can be induced in cobalt(II) compounds by smaller external stimuli such as confinement in host lattices (e.g., $\left.\left[\mathrm{Fe}_{0.83} \mathrm{Co}_{0.17}\left(\mathrm{tpy}_{2}\right]_{2}\right] \mathrm{PF}_{6}\right]_{2}$ displays cobalt-based SCO) [16] or phase transitions enabled by interchain interactions of alkyl substituted tpy ligands $4^{\prime}$-R-tpy [97]. Furthermore, cobalt(II) complexes with certain $4^{\prime}$-substituted terpyridine ligands $\mathrm{R}$-tpy with $\mathrm{R}=\mathrm{OC}_{14} \mathrm{H}_{29}, \mathrm{OC}_{16} \mathrm{H}_{33}$ display 
"reverse SCO" with the low-spin state populated at higher temperature instead of the conventional temperature dependence $[97,98]$.

$\left[\mathrm{Co}\left(\mathrm{tpy}_{2}\right)_{2}\right]\left[\mathrm{BF}_{4}\right]_{2}$ has been characterized crystallographically between $30 \mathrm{~K}$ and $375 \mathrm{~K}$. The XRD data reveal a Jahn-Teller [59] distorted low-spin complex at $30 \mathrm{~K}$ with distances to two terminal pyridines of one tpy ligand elongated and a high-spin fraction $>87 \%$ at $375 \mathrm{~K}$ [99]. Similar to $\left[\mathrm{Co}\left(\mathrm{tpy}_{2}\right)_{2}\right]\left[\mathrm{PF}_{6}\right]_{2}$, mer- $\left[\mathrm{Co}(\mathrm{ddpd})_{2}\right]\left[\mathrm{BF}_{4}\right]_{2} \times 1.5 \mathrm{H}_{2} \mathrm{O}$ remains in the high-spin state down to low temperature [62]. The crystallographic data of mer-[Co(ddpd) $\left.)_{2}\right]\left[\mathrm{BF}_{4}\right]_{2} \times 2 \mathrm{CH}_{3} \mathrm{CN}$ at $193 \mathrm{~K}$ show no sign for a Jahn-Teller distortion, which would be expected for a low-spin $\mathrm{d}^{7}$ system (Table 1, Figure 6a). The magnetic susceptibility of mer-[Co(ddpd $\left.)_{2}\right]\left[\mathrm{BF}_{4}\right]_{2} \times 1.5 \mathrm{H}_{2} \mathrm{O}$ at $300 \mathrm{~K}$ amounts to $\chi \mathrm{T}=2.53 \mathrm{~cm}^{3}$ $\mathrm{K} \mathrm{mol}^{-1}$ (Table 5), similar to $\left[\mathrm{Co}(\text { tpy) })_{2}\right]\left[\mathrm{ClO}_{4}\right]_{2}$ at $300 \mathrm{~K}$ [95]. mer-[Co(ddpd) $\left.)_{2}\right]\left[\mathrm{BF}_{4}\right]_{2} \times 1.5 \mathrm{H}_{2} \mathrm{O}$ displays a typical $\chi \mathrm{T}$ versus $\mathrm{T}$ profile for a high-spin cobalt(II) ion with spin-orbit coupling in a distorted environment at lower temperature without any sign for SCO [62]. In mixed crystals of $\left[\mathrm{Fe}_{0.83} \mathrm{Co}_{0.17}\left(\mathrm{tpy}_{2}\right)_{2}\right]\left[\mathrm{PF}_{6}\right]_{2}$ the iron(II) host lattice destabilizes the high-spin state of cobalt(II) to such an extent that the low-spin state prevails up to $250 \mathrm{~K}$ and SCO sets in close to room temperature [16]. Furthermore, $\left[\mathrm{Co}(\mathrm{tpy})_{2}\right]^{2+}$ appears as a rapidly equilibrating mixture of low- and high-spin species in solution (acetonitrile, methanol, water) $[100,101]$. Both $\left[\mathrm{Co}\left(\mathrm{tpy}_{2}\right)_{2}\right]^{2+}$ and $\left[\mathrm{Co}(\mathrm{ddpd})_{2}\right]^{2+}$ exhibit characteristic paramagnetically shifted but sharp ${ }^{1} \mathrm{H}$ NMR spectra [62,68]. In addition, [Co(ddpd $\left.)_{2}\right]^{2+}$ displays sharp ${ }^{13} \mathrm{C}$ NMR resonances between $\delta=+602 \mathrm{ppm}$ and $\delta=-216 \mathrm{ppm}$ in $\mathrm{CD}_{3} \mathrm{CN}$ at room temperature [62].

The electronic spectrum of $\left[\mathrm{Co}(\mathrm{ddpd})_{2}\right]^{2+}$ in $\mathrm{CH}_{3} \mathrm{CN}$ displays prominent $\pi-\pi^{*}$ and charge transfer bands of the ddpd ligands at 24,330 $\left(980 \mathrm{M}^{-1} \mathrm{~cm}^{-1}\right), 32,365\left(31,000 \mathrm{M}^{-1} \mathrm{~cm}^{-1}\right)$ and 40,325 $\left(32,000 \mathrm{M}^{-1} \mathrm{~cm}^{-1}\right) \mathrm{cm}^{-1}$ [62]. In addition, four weak ligand field bands of the cobalt(II) centre appear at 11,045 $\left(5 \mathrm{M}^{-1} \mathrm{~cm}^{-1}\right), 15,195\left(2 \mathrm{M}^{-1} \mathrm{~cm}^{-1}\right), 18,425\left(9 \mathrm{M}^{-1} \mathrm{~cm}^{-1}\right.$, sh) and 21,090 $\mathrm{cm}^{-1}$ (40 $\mathrm{M}^{-1} \mathrm{~cm}^{-1}$; superimposed on a $\pi-\pi^{*}$ band) (Figure 7) [62]. Two spin-allowed ${ }^{4} \mathrm{~T}_{1} \rightarrow{ }^{4} \mathrm{~T}_{2}$ and ${ }^{4} \mathrm{~T}_{1} \rightarrow{ }^{4} \mathrm{~T}_{1}(\mathrm{P})$ ligand-field bands are expected in $\mathrm{O}$ symmetry. The lower tetragonal symmetry of $\left[\mathrm{Co}(\mathrm{ddpd})_{2}\right]^{2+}$ (compressed octahedron along $\mathrm{z}$, Table 1$)$ splits the $t_{2 \mathrm{~g}}$ and $\mathrm{e}_{\mathrm{g}}$ levels enabling four transitions. The observed bands can then be interpreted as $\mathrm{d}_{x z / y z} \rightarrow \mathrm{d}_{x 2-y 2}, \mathrm{~d}_{x y} \rightarrow \mathrm{d}_{x 2-y 2}, \mathrm{~d}_{x z / y z} \rightarrow \mathrm{d}_{\mathrm{z} 2}$ and $d_{x y} \rightarrow d_{z 2}$ excitations leading to averaged tetragonal splittings of the $t_{2 g}$ and $e_{g}$ levels of 3410 and $6635 \mathrm{~cm}^{-1}$, respectively and an averaged ligand field splitting $\Delta_{\mathrm{o}}$ of $16,440 \mathrm{~cm}^{-1}$. This value of $\Delta_{\mathrm{o}}$ is quite high and should enable SCO under appropriate conditions. In single crystals of $\left[\mathrm{Co}\left(\mathrm{tpyy}_{2}\right]\left[\mathrm{PF}_{6}\right]_{2}\right.$ (high-spin) two ligand field bands are discernible at 9200 and $11,600 \mathrm{~cm}^{-1}$, assigned to the split components of the ${ }^{4} \mathrm{~T}_{1} \rightarrow{ }^{4} \mathrm{~T}_{2}$ transition in the distorted octahedron. For $\left[\mathrm{Co}(\mathrm{bpy})_{3}\right]\left[\mathrm{NaRh}(\mathrm{ox})_{3}\right]$ a band at $11,500 \mathrm{~cm}^{-1}$ has been assigned to the ${ }^{4} \mathrm{~T}_{1} \rightarrow{ }^{4} \mathrm{~T}_{2}$ transition (without addressing the trigonal splitting). Further transitions of tpy and bpy complexes are masked by MLCT transitions [16].

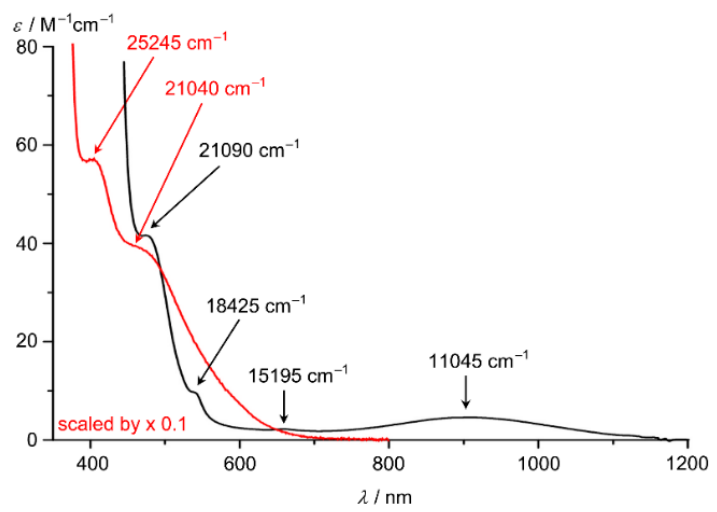

Figure 7. UV/Vis/NIR spectra of $\left[\mathrm{Co}(\mathrm{ddpd})_{2}\right]^{2+}\left(\right.$ black) and $\left[\mathrm{Co}(\mathrm{ddpd})_{2}\right]^{3+}($ red, scaled by 0.1$)$ in $\mathrm{CH}_{3} \mathrm{CN}$; ligand field bands indicated by arrows [62]. 
Both cobalt(II) complexes undergo a reversible oxidation to the cobalt(III) complexes at low potential (Table 4). $\left[\mathrm{Co}(\mathrm{ddpd})_{2}\right]^{2+}$ is easier to oxidize than $\left[\mathrm{Co}(\mathrm{tpy})_{2}\right]^{2+}$, likely due to the more electronrich nature of ddpd (Table 4). Chemical oxidation of $\left[\mathrm{Co}(\mathrm{tpy})_{2}\right]\left[\mathrm{PF}_{6}\right]_{2}$ with bromine and of $\left[\mathrm{Co}(\mathrm{ddpd})_{2}\right]\left[\mathrm{BF}_{4}\right]_{2}$ with silver triflate, silver tetrafluoroborate or 2,3-dichloro-5,6-dicyano-1,4benzoquinone (and counter ion exchange) yields the corresponding diamagnetic low-spin cobalt(III) complexes $\left[\mathrm{Co}(\text { tpy })_{2}\right]^{3+}$ and $\left[\mathrm{Co}(\mathrm{ddpd})_{2}\right]^{3+}$, respectively (Table 3) $[62,68,100,102,103]$. $\left[\mathrm{Co}(\text { tpy })_{2}\right]^{3+}$ displays the lowest value $S(\mathrm{OC}-6)=1.22$ of the terpyridine series and $\left[\mathrm{Co}(\mathrm{ddpd})_{2}\right]^{3+}$ is almost perfectly octahedral with $S($ OC-6) $=0.10$ (Tables 1 and 2; Figure $6 \mathrm{c}$ ), underscoring the high electronic symmetry of the $\left(t_{2 g}\right)^{6}$ electron configuration.

The low-spin $\mathrm{d}^{6}$ cobalt(III) complex $\left[\mathrm{Co}(\mathrm{ddpd})_{2}\right]^{3+}$ displays two absorption bands at 21,040 and $25,245 \mathrm{~cm}^{-1}$ (superimposed onto $\pi-\pi^{*}$ and charge transfer bands; maxima fit by Gaussian bands, Figure 7) which can be assigned to the spin-allowed ligand field transitions ${ }^{1} \mathrm{~A}_{1} \rightarrow{ }^{1} \mathrm{~T}_{1}$ and ${ }^{1} \mathrm{~A}_{1} \rightarrow{ }^{1} \mathrm{~T}_{2}$, respectively [104]. The lower energy corresponds to the ligand field splitting $\Delta_{\mathrm{o}}=21,040 \mathrm{~cm}^{-1}$. The ligand field bands of $\left[\mathrm{Co}(\text { phen })_{3}\right]^{3+}$ have been reported as $29,240-28,985 \mathrm{~cm}^{-1}$ and $21,786-21,882 \mathrm{~cm}^{-1}$, respectively [105]. The ligand field splitting induced by ddpd is hence smaller than that of phen in the cobalt(III) complexes.

The second order rate constant for the self-exchange reaction $\left[\mathrm{Co}(\mathrm{tpy})_{2}\right]^{3+/ 2+}$ has been determined as $k_{\mathrm{ex}}=2820-3000 \mathrm{M}^{-1} \mathrm{~s}^{-1}$ (in $\mathrm{H}_{2} \mathrm{O}$ ) between low-spin $\mathrm{Co}^{\mathrm{II}}$ and low-spin $\mathrm{Co}^{\mathrm{III}}[106,107]$. Much lower rate constants of $k_{\mathrm{ex}}=41.7$ and $17.5 \mathrm{M}^{-1} \mathrm{~s}^{-1}$ have been reported for the $\left[\mathrm{Co}(\mathrm{phen})_{3}\right]^{3+/ 2+}$ and $\left[\mathrm{Co}(\text { bpy })_{3}\right]^{3+/ 2+}$ pairs, respectively $[106,107]$. This can be traced back to the different spin states of $\left[\mathrm{Co}(\text { tpy })_{2}\right]^{2+}$ (mainly low-spin) and $\left[\mathrm{Co}(\text { phen })_{3}\right]^{2+} /\left[\mathrm{Co}(\mathrm{bpy})_{3}\right]^{2+}$ (high-spin) at room temperature in solution. In any case, self-exchange is comparably slow on the ${ }^{1} \mathrm{H}$ NMR timescale and this holds for the $\left[\mathrm{Co}(\mathrm{ddpd})_{2}\right]^{3+/ 2+}$ couple as well [62]. In addition to the spin-barrier for the ddpd complexes, the $\mathrm{Co}-\mathrm{N}$ bond lengths $\mathrm{Co}-\mathrm{N} 2$ and $\mathrm{Co}-\mathrm{N} 1 / 3$ decrease by 0.148 and $0.166 \AA$ upon oxidation (Table 1 ). Similarly, the averaged $\mathrm{Co}-\mathrm{N} 2$ and $\mathrm{Co}-\mathrm{N} 1 / \mathrm{N} 3$ bond lengths of the tpy complexes shrink by 0.149 and $0.200 \AA$, respectively (Table 2). Obviously, the large reorganization energies (irrespective of the $\mathrm{Co}^{\mathrm{II}}$ spin state) mainly account for the comparably slow electron transfer rates. Even smaller self-exchange rate constants are found for $\mathrm{Co}^{\mathrm{III} / \mathrm{II}}$ complexes of aliphatic amines, such as $\left[\mathrm{Co}(\mathrm{en})_{3}\right]^{3+/ 2+}$ with $k_{\mathrm{ex}}=2 \times 10^{-5} \mathrm{M}^{-1} \mathrm{~s}^{-1}$ [108]. This has been ascribed to the innocent nature of ethylene diamine in contrast to the redox-activity of bpy or phen ligands. The latter enable a strong electronic coupling via $\pi^{*}$ orbitals of the ligands in the electron transfer step, for example via the ubiquitous "phenyl embraces" of polypyridine complexes (Figure 2) [72]. As ddpd is a poor electron acceptor, electron transfer to $\left[\mathrm{Co}(\mathrm{ddpd})_{2}\right]^{3+}$ is retarded by the high-lying $\pi^{*}$ orbitals of ddpd.

The slow electron transfer kinetics of the reduction of $\left[\mathrm{Co}(\mathrm{ddpd})_{2}\right]^{3+}$ can be beneficial for applications in dye-sensitized solar cells, retarding the undesired back-electron transfer (recombination) at the $\mathrm{TiO}_{2}$ electrode [102]. However, dye-regeneration by [Co(ddpd $\left.)_{2}\right]^{2+}$ is also slow [103]. Compared to the standard iodide/triiodide electrolyte, the overall performance of outer sphere cobalt(III/II) electrolytes in dye-sensitized solar cells depends on the dye and the electrode surface treatment among other factors $[102,103,109,110]$.

Reduction of $\left[\mathrm{Co}^{\mathrm{II}}\left(\mathrm{tpy}_{2}\right)_{2}\right]^{2+}$ leads to $\left[\mathrm{Co}^{\mathrm{I}}(\mathrm{tpy})_{2}\right]^{+}$and then to $\left[\mathrm{Co}(\text { tpy })_{2}\right]^{0}$ (Table 4) [20]. The latter neutral species has been described either as $\left[\mathrm{Co}^{\mathrm{I}}\left(\text { tpy } \cdot{ }^{-}\right)(\text {tpy })\right]^{0}[20]$ or as $\left[\mathrm{Co}^{\mathrm{II}}\left(\mathrm{tpy}^{\cdot} \cdot^{-}\right)_{2}\right]^{0}[24]$. After the loss of one tpy ligand, the resulting species catalyses the electroreduction of $\mathrm{CO}_{2}$ to $\mathrm{CO}$ and of protons to $\mathrm{H}_{2}$ [20]. The ddpd complex $\left[\mathrm{Co}^{\mathrm{II}}(\mathrm{ddpd})_{2}\right]^{2+}$ is irreversibly reduced at $-1.80 \mathrm{~V}$. This reduction occurs at a potential $0.58 \mathrm{~V}$ less negative than the ligand-centred reduction of the $\left[\mathrm{Zn}^{\mathrm{II}}(\mathrm{ddpd})_{2}\right]^{2+}$ complex, suggesting that the cobalt(II) ion is reduced to cobalt(I) similar to the $\left[\mathrm{Co}(\mathrm{tpy})_{2}\right]^{2+/+}$ reduction process (Table 4). The $\left[\mathrm{Co}^{\mathrm{I}}(\text { tpy })_{2}\right]^{+}$monocation features some $\pi$ back-donation into the $\pi^{*}$ orbitals of tpy [24]. However, the strongly electron donating character of ddpd is incompatible with back-donation from a d $^{8}$-cobalt(I) centre and consequently the $\left[\mathrm{Co}^{\mathrm{II} / \mathrm{I}}(\mathrm{ddpd})_{2}\right]^{2+/+}$ process becomes irreversible, likely caused by partial or full dissociation of ddpd. 
The mer- and cis-fac isomers of $\left[\mathrm{Co}(\mathrm{ddpd})_{2}\right]^{2+}$ constitute the first structurally confirmed example for the ability of ddpd to coordinate as pincer and as tripodal ligand. The $\left[\mathrm{Co}(\mathrm{L})_{2}\right]^{3+/ 2+}$ and $\left[\mathrm{Co}(\mathrm{L})_{2}\right]^{2+/+}$ redox couples are metal centred for both ligands, yet $\left[\mathrm{Co}(\mathrm{ddpd})_{2}\right]^{+}$is unstable. Electron transfer involving $\left[\mathrm{Co}(\mathrm{ddpd})_{2}\right]^{2+}$ or $\left[\mathrm{Co}(\mathrm{ddpd})_{2}\right]^{3+}$ is slow. Spin-crossover behaviour is found for several $\left[\mathrm{Co}(\text { tpy })_{2}\right]^{2+}$ salts but not yet for $\left[\mathrm{Co}(\mathrm{ddpd})_{2}\right]^{2+}$ salts $\left(\mathrm{X}=\mathrm{BF}_{4}^{-}\right)$.

\section{7. $m e r-\left[\mathrm{Fe}(\mathrm{ddpd})_{2}\right]^{2+}\left[\mathrm{d}^{6}\right]$ and $m e r-\left[\mathrm{Fe}(\mathrm{ddpd})_{2}\right]^{3+}\left[\mathrm{d}^{5}\right]$}

$\left[\mathrm{Fe}(\mathrm{ddpd})_{2}\right]^{2+}$ salts are conveniently prepared from $\mathrm{Fe}\left[\mathrm{BF}_{4}\right]_{2} \times 6 \mathrm{H}_{2} \mathrm{O}$ and ddpd or from $\mathrm{FeBr}_{2} /$ ddpd followed by anion exchange with $\left[\mathrm{NH}_{4}\right]\left[\mathrm{PF}_{6}\right]$ (Scheme 3) [64], similar to the well-known $\left[\mathrm{Fe}(\mathrm{tpy})_{2}\right]^{2+}$ complexes $[25,111]$. Both $\mathrm{d}^{6}$ iron(II) complexes $\left[\mathrm{Fe}(\mathrm{tpy})_{2}\right]^{2+}$ and $\left[\mathrm{Fe}(\mathrm{ddpd})_{2}\right]^{2+}$ are diamagnetic low-spin complexes with $\left(\mathrm{t}_{2 \mathrm{~g}}\right)^{6}$ electron configuration at room temperature. Both complex cations deliver sharp and well-resolved NMR spectra (Tables 3 and 6). Coordination of iron(II) to tpy and ddpd results in a significant ${ }^{15} \mathrm{~N}$ shielding effect of the pyridine nitrogen nuclei [112]. The effect is more pronounced for the terminal pyridines (N1) than for the inner one (N2) in both cases (Table 6). Yet, the relative ${ }^{15} \mathrm{~N}$ coordination shift difference between $\mathrm{N} 1$ and $\mathrm{N} 2$ is much larger for the tpy complex (49 ppm) than for the ddpd derivative (23 ppm), possibly arising from the different symmetry (Tables 1 and 2). Interestingly, the coordination shift does not correlate with the $\mathrm{M}-\mathrm{N}$ distances in the solid state (Tables 1 and 2) [112]. Expectedly, the ${ }^{15} \mathrm{~N}$ chemical shift of the bridging $\mathrm{N}-\mathrm{Me}$ groups of ddpd is hardly affected by the iron(II) coordination (Table 6).

Table 6. Coordination shift $\delta=\delta($ complex $)-\delta($ ligand $)$ of ${ }^{15} \mathrm{~N}$ resonances of diamagnetic $\left[\mathrm{Fe}(\mathrm{L})_{2}\right]^{2+}$ complexes in $\mathrm{CD}_{3} \mathrm{CN}(\mathrm{L}=\mathrm{ddpd}$, tpy).

\begin{tabular}{ccc}
\hline & L $=\operatorname{ddpd}^{[\mathbf{a}]}$ & $\mathbf{L}=$ tpy $^{[\mathbf{b}]}$ \\
\hline$\Delta \delta(\mathrm{N} 1) / \mathrm{ppm}$ & $-56.2[64,113]$ & $-61.6^{[\mathrm{c}]}$ \\
$\Delta \delta(\mathrm{N} 2) / \mathrm{ppm}$ & $-33.2[64,113]$ & $-12.4^{[\mathrm{c}]}$ \\
$\Delta \delta(\mathrm{N} 7) / \mathrm{ppm}$ & $+3.2[64,113]$ & - \\
\hline
\end{tabular}

[a] Relative to $\delta(\mathrm{N} 1(\mathrm{ddpd}))=-84.8 \mathrm{ppm} ; \delta(\mathrm{N} 2(\mathrm{ddpd}))=-124.1 \mathrm{ppm} ; \delta(\mathrm{N} 7(\mathrm{ddpd}))=-283.1 \mathrm{ppm}\left(\mathrm{CD}_{3} \mathrm{CN}\right)[35,113]$.

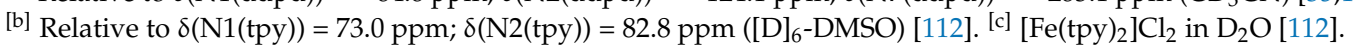

In the Mößbauer spectra of the tpy and ddpd iron(II) complexes, the quadrupole doublets appear at $\delta=0.28 \mathrm{~mm} \mathrm{~s}^{-1}$ and $\delta=0.39 \mathrm{~mm} \mathrm{~s}^{-1}$, respectively [25,64]. The quadrupole splitting of $\Delta E_{\mathrm{Q}}=1.05 \mathrm{~mm} \mathrm{~s}^{-1}$ of the tpy complex surpasses that of the ddpd complex with $\Delta E_{\mathrm{Q}}=0.40 \mathrm{~mm} \mathrm{~s}^{-1}$ suggesting a much higher symmetry of the $\left[\mathrm{Fe}(\mathrm{ddpd})_{2}\right]^{2+}$ complex ion $[25,64]$. This is also reflected in the stronger deviation of the tpy complex from octahedral symmetry (Tables 1 and 2).

Refluxing a solution of $\left[\mathrm{Fe}(\mathrm{ddpd})_{2}\right]^{2+}$ in $\mathrm{CH}_{3} \mathrm{CN}$ does not lead to spin-crossover $(\mathrm{SCO})$ to the ${ }^{5} \mathrm{~T}_{2}$ high-spin state but to ligand dissociation [64]. Under these conditions, the $\left[\mathrm{Fe}\left(\mathrm{tpy}_{2}\right)_{2}\right]^{2+}$ ion is thermally stable but does not undergo SCO either. This suggests a too strong ligand field splitting in both complexes. Substitution of tpy at the sterically unhindered $4,4^{\prime \prime}$ positions retains the low-spin ground state [111]. On the other hand, substituents at the $\alpha$ positions $\left(6,6^{\prime \prime}\right)(\mathrm{X}=\mathrm{F}, \mathrm{Cl}, \mathrm{Br})$ lead to a diminished ligand field strength and high-spin ground states $(X=C l, B r)$ or SCO behaviour $(X=F)[114,115]$.

Increasing the steric bulk at the bridging nitrogen atom of ddpd in $\left[\mathrm{Fe}\left({ }^{\mathrm{n}} \mathrm{Pr}_{2} \mathrm{tpda}\right)_{2}\right]^{2+}$ and $\left[\mathrm{Fe}\left({ }^{\mathrm{n}} \mathrm{Hex}_{2} \mathrm{tpda}\right)_{2}\right]^{2+}$ complexes (see Scheme 2 for $\mathrm{R}_{2}$ tpda ligands) increases the hydrolytic lability of the iron(II) complexes, yet the electronic structure remains low-spin iron(II) [43]. The parent complex $\left[\mathrm{Fe}\left(\mathrm{H}_{2} \text { tpda }\right)_{2}\right]^{2+}$ is in the low-spin state as well [116]. In acetonitrile solution, deprotonation at the $\mathrm{NH}$ groups of $\left[\mathrm{Fe}\left(\mathrm{H}_{2} \mathrm{tpda}\right)_{2}\right]^{2+}$ readily occurs for example in the ESI mass spectrometer [43].

In contrast to the $\mathrm{Zn}^{2+}$ /chloride/ddpd system (see above), bromide ions cannot compete with ddpd for iron(II) coordination sites and $\left[\mathrm{Fe}(\mathrm{ddpd})_{2}\right] \mathrm{Br}_{2}$ can be isolated and crystallized (Figure 8) in addition to the salts with weakly coordinating anions $\mathrm{BF}_{4}{ }^{-}$or $\mathrm{PF}_{6}{ }^{-}$(Table 1) [64]. The $\mathrm{Fe}{ }^{\cdots} \mathrm{Br}$ distance amounts to $6.6 \AA$, indicating an electrostatic interaction at best but no coordination. In all $\left[\mathrm{Fe}(\mathrm{ddpd})_{2}\right][\mathrm{X}]_{2}$ salts, the geometry of the dications is close to octahedral with $S(\mathrm{OC}-6)<0.2$ (Table 1$)$. 


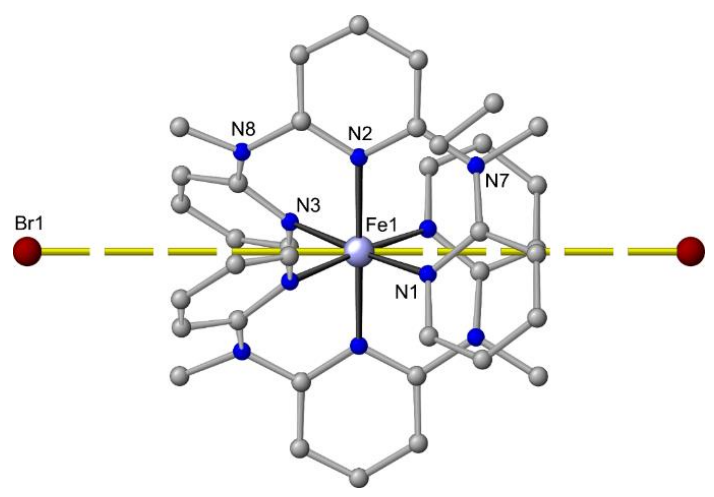

Figure 8. Molecular structure of mer-[Fe( $\left.\mathrm{ddpd})_{2}\right] \mathrm{Br}_{2}$ in the solid state; hydrogen atoms and solvent molecules omitted. Atom numbering unified for clarity. $\mathrm{Fe}{ }^{\cdots} \mathrm{Br}$ distances indicated by yellow dashed lines.

Addition of ddpd to $\left[\mathrm{Fe}(\mathrm{tpy})_{2}\right]^{2+}$ does not displace tpy. In contrast, tpy is able to substitute ddpd in $\left[\mathrm{Fe}(\mathrm{ddpd})_{2}\right]^{2+}$, as easily judged from the colour change from orange-brown ([Fe(ddpd $\left.\left.)_{2}\right]^{2+}\right)$ to purple $\left(\left[\mathrm{Fe}(\mathrm{tpy})_{2}\right]^{2+}\right)$. The characteristic purple colour of $\left[\mathrm{Fe}(\mathrm{tpy})_{2}\right]^{2+}$ is commonly assigned to a MLCT transition at $552 \mathrm{~nm}$ enabled by the low-energy $\pi^{*}$ orbitals of tpy [111]. The $\pi^{*}$ orbitals of ddpd are at higher energy and consequently the MLCT absorption of $\left[\mathrm{Fe}(\mathrm{ddpd})_{2}\right]^{2+}$ is strongly hypsochromically shifted to $395 \mathrm{~nm}$ [64].

Consistent with the stronger electron donating character of ddpd, the $\left[\mathrm{Fe}(\mathrm{ddpd})_{2}\right]^{3+/ 2+}$ redox process occurs at lower potential than the corresponding $\left[\mathrm{Fe}(\mathrm{tpy})_{2}\right]^{3+/ 2+}$ process by $0.38 \mathrm{~V}$ (Table 4). According to Mößbauer spectroscopy, these redox processes are metal centred giving the corresponding low-spin iron(III) complexes with $\left(\mathrm{t}_{2 \mathrm{~g}}\right)^{5}$ electron configuration $\left(\left[\mathrm{Fe}(\mathrm{tpy})_{2}\right]^{3+}\right.$ : $\left.\delta=0.07 \mathrm{~mm} \mathrm{~s}^{-1} ;\left[\mathrm{Fe}(\mathrm{ddpd})_{2}\right]^{3+}: \delta=0.11 \mathrm{~mm} \mathrm{~s}^{-1}\right)[25,64]$. Similar, to the parent iron(II) complexes, the quadrupole splitting is larger in the tpy complex $\left(\left[\mathrm{Fe}(\mathrm{tpy})_{2}\right]^{3+}: \Delta E_{\mathrm{Q}}=3.43 \mathrm{~mm} \mathrm{~s}^{-1}\right.$; $\left[\mathrm{Fe}(\mathrm{ddpd})_{2}\right]^{3+}$ : $\Delta E_{\mathrm{Q}}=1.97 \mathrm{~mm} \mathrm{~s}^{-1}$ ) due to its reduced symmetry. The anisotropic EPR spectra of $\left[\mathrm{Fe}(\mathrm{bpy})_{3}\right]^{3+}$ and $\left[\mathrm{Fe}(\mathrm{ddpd})_{2}\right]^{3+}$ in frozen solution are typical of low-spin ferric species $(S=1 / 2)$ with $g=2.68,2.60$, 2.01 and $g=2.49,2.30,1.82$, respectively $[25,64]$. An irreversible ligand-centred oxidation is found for $\left[\mathrm{Fe}(\mathrm{ddpd})_{2}\right]^{3+}$ at $1.63 \mathrm{~V}$ (Table 4), while no further oxidation process has been reported for $\left[\mathrm{Fe}(\mathrm{tpy})_{2}\right]^{3+}$. $\left[\mathrm{Fe}(\text { tpy })_{2}\right]^{2+}$ can be reversibly reduced twice to give $\left[\mathrm{Fe}^{\mathrm{II}}\left(\mathrm{tpy}^{-}{ }^{-}\right)(\text {tpy })\right]^{+}$and $\left[\mathrm{Fe}^{\mathrm{II}}\left(\mathrm{tpy}^{-{ }^{-}}\right)_{2}\right]^{0}$, respectively, similar to $\left[\mathrm{Zn}(\operatorname{tpy})_{2}\right]^{2+}$ (Table 4) [25]. On the other hand, $\left[\mathrm{Fe}(\mathrm{ddpd})_{2}\right]^{2+}$ is only irreversibly reduced at the ddpd ligand, at a similar potential as the [Zn(ddpd) ${ }_{2}^{2+}$ complex (Table 4) [64].

Replacement of a ddpd ligand by the electron accepting tridentate dcpp ligand give the deep blue-coloured heteroleptic push-pull substituted complex [Fe(dcpp)(ddpd) $]^{2+}$ (Scheme 5) [64]. The colour arises from a strong charge transfer absorption band peaking at $592 \mathrm{~nm}$ and tailing into the near-IR. According to time-dependent DFT calculations, the lowest energy components are of mixed MLCT (iron(II) $\rightarrow$ dcpp) and LL'CT (ddpd $\rightarrow$ dcpp) character. The homoleptic complex $\left[\mathrm{Fe}(\mathrm{dcpp})_{2}\right]^{2+}$ prepared by McCusker features charge transfer bands as well but these are of pure MLCT nature $[64,117]$. After excitation of the charge transfer bands of $\left[\mathrm{Fe}(\mathrm{dcpp})_{2}\right]^{2+}$ and $[\mathrm{Fe}(\mathrm{dcpp})(\mathrm{ddpd})]^{2+}$, transient absorption spectroscopy reveals a rapid recovery of the ground state with $\tau=280$ and $548 \mathrm{ps,}$ respectively. This unusually fast relaxation in the picosecond range has been tentatively assigned to a shortened relaxation cascade ${ }^{1} \mathrm{MLCT} \rightarrow{ }^{3} \mathrm{MLCT} \rightarrow{ }^{3} \mathrm{MC}\left({ }^{3} \mathrm{~T}_{1}\right)$, omitting the ${ }^{5} \mathrm{MC}\left({ }^{5} \mathrm{~T}_{2}\right)$ high-spin state with typical lifetimes in the nanosecond range $[64,117]$. It has been proposed that the very large ligand field splitting in these complexes shifts the ${ }^{5} \mathrm{~T}_{2}$ state close to or even above the ${ }^{3} \mathrm{~T}_{1}$ excited state. However, non-radiative relaxation via the ${ }^{3} \mathrm{~T}_{1}$ states is still too fast to allow for a long-lived ${ }^{3} \mathrm{MLCT}$ state, as has been established recently in polycarbene iron(II) complexes [118-122]. 

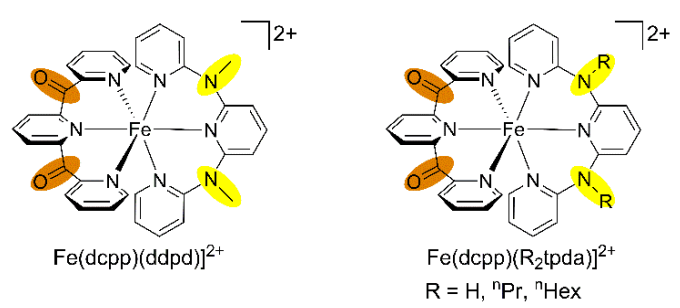

Scheme 5. Heteroleptic iron(II) complexes of ddpd/ $\mathrm{R}_{2}$ tpda and dcpp.

The analogous heteroleptic complexes $\left[\mathrm{Fe}(\mathrm{dcpp})\left(\mathrm{R}_{2} \mathrm{tpda}\right)\right]^{2+}\left(\mathrm{R}=\mathrm{H},{ }^{\mathrm{n}} \mathrm{Pr},{ }^{\mathrm{n}} \mathrm{Hex}\right.$; Scheme 5) feature charge transfer properties similar to those of [Fe(dcpp)(ddpd) ${ }^{2+}[43]$. Furthermore, stepwise deprotonation of $\left[\mathrm{Fe}(\mathrm{dcpp})\left(\mathrm{H}_{2} \mathrm{tpda}\right)\right]^{2+}$ at the bridging nitrogen atoms of $\mathrm{H}_{2}$ tpda yields the deep green, reasonably stable conjugate bases $[\mathrm{Fe}(\mathrm{dcpp})(\mathrm{Htpda})]^{+}$and $[\mathrm{Fe}(\mathrm{dcpp})(\mathrm{tpda})]^{0}$. These can be reversibly re-protonated with trifluoroacetic acid to $\left[\mathrm{Fe}(\mathrm{dcpp})\left(\mathrm{H}_{2} \mathrm{tpda}\right)\right]^{2+}$ or irreversibly methylated with methyl iodide to $[\mathrm{Fe}(\mathrm{dcpp})(\mathrm{ddpd})]^{2+}$. The charge transfer band maxima of $[\mathrm{Fe}(\mathrm{dcpp})(\mathrm{Htpda})]^{+}$ and $[\mathrm{Fe}(\mathrm{dcpp})(\mathrm{tpda})]^{0}$ are shifted to 613 and $682 \mathrm{~nm}$ with respect to that of their conjugate acid $\left[\mathrm{Fe}(\mathrm{dcpp})\left(\mathrm{H}_{2} \mathrm{tpda}\right)\right]^{2+}(592 \mathrm{~nm})$ [43]. Moreover, additional bands appear at 724 and $872 \mathrm{~nm}$, respectively. TD-DFT calculations suggest that these low-energy bands arise from LL'CT transitions, namely from the amide units localized at the $[\mathrm{Htpda}]^{-} /[\mathrm{tpda}]^{2-}$ ligands to the dcpp ligand without significant iron participation. The combined MLCT and LL'CT absorptions cover the spectral range from $600 \mathrm{~nm}$ to more than $1000 \mathrm{~nm}$ [43]. The low-energy ${ }^{1} \mathrm{LL}$ 'CT transitions are dipole and spin allowed. However, emission from the corresponding ${ }^{3}$ LL'CT states is not observed. Possibly, the $\pi$-donor character of the pyridyl amide ligands [Htpda] ${ }^{-}$and [tpda $]^{2-}$ also decrease the ligand field splitting and consequently favour rapid non-radiative relaxation via the low-energy ${ }^{3} \mathrm{MC}\left({ }^{3} \mathrm{~T}_{1}\right)$ and ${ }^{5} \mathrm{MC}\left({ }^{5} \mathrm{~T}_{2}\right)$ states.

All iron(II) and iron(III) complexes of the oligopyridine ligands tpy and ddpd are low-spin complexes due to the large ligand field splitting in all cases. SCO is not observed. Ligand-centred reductions are reversible for the tpy complex but irreversible for the ddpd complex. The iron(III/II) couple is reversible for both complex types. MLCT bands appear in the visible spectral region for $\left[\mathrm{Fe}(\mathrm{tpy})_{2}\right]^{2+}$ due to the low-energy $\pi^{*}$ orbitals of tpy but in the UV for the ddpd complex. The heteroleptic complex $[\mathrm{Fe}(\mathrm{dcpp})(\mathrm{ddpd})]^{2+}$ displays MLCT bands with $\mathrm{Fe} \rightarrow \mathrm{dcpp}$ and LL'CT bands with ddpd $\rightarrow$ dcpp character in the Vis-NIR region.

\section{8. $\left[\operatorname{Mn}(\mathrm{ddpd})_{2}\right]^{n+}$}

Neither homo- nor heteroleptic complexes of manganese and ddpd have been reported so far. In contrast, colourless complexes of the type $\left[\mathrm{Mn}(\mathrm{tpy})_{2}\right]^{2+}$ are easily formed from $\mathrm{MnCl}_{2} \times 4 \mathrm{H}_{2} \mathrm{O}$, tpy and counter ion exchange, for example by perchlorate [87]. The manganese(II) complex cation features a high-spin $\mathrm{d}^{5}$ electron configuration $(S=5 / 2)$ with $\chi \mathrm{T}=4.62 \mathrm{~cm}^{3} \mathrm{~K} \mathrm{~mol}^{-1}$ at room temperature (Table 5) [87]. Expectedly, ligand field transitions are Laporte and spin-forbidden and only $\pi-\pi^{*}$ transitions appear at 284, 323 and $335 \mathrm{~nm}$ in $\mathrm{CH}_{3} \mathrm{CN}$ [123]. The coordination geometry of the 4'-tolyl derivative $\left[\mathrm{Mn}(\text { Tol-tpy })_{2}\right]^{2+}$ is compressed octahedral due to the ligand bite angle [70]. [Mn(tpy $\left.)_{2}\right]^{2+}$ displays a rich redox chemistry $[26,87,123]$. Oxidation to the high-spin $\mathrm{d}^{4}$ manganese(III) complex $\left[\mathrm{Mn}(\mathrm{tpy})_{2}\right]^{3+}$ occurs at $0.86 \mathrm{~V}$ (Table 4). The 4'-tolyl tpy derivative $\left[\mathrm{Mn}(\text { Tol-tpy })_{2}\right]^{3+}$ shows a tetragonally compressed octahedral geometry due to the Jahn-Teller [59] effect and the ligand bite angle [70]. Heteroleptic complexes easily form in higher oxidation states. Binuclear mixed-valent di- $\mu$-oxido terpyridine manganese complexes such as $\left[\left(\mathrm{H}_{2} \mathrm{O}\right)(\operatorname{tpy}) \mathrm{Mn}^{\mathrm{III}}(\mu-\mathrm{O}){ }_{2} \mathrm{Mn}^{\mathrm{IV}}\left(\mathrm{H}_{2} \mathrm{O}\right)(\text { tpy })\right]^{3+}$ have been extensively studied as functional models of the oxygen-evolving centre of photosystem II [124,125].

Tpy-centred reductions are found for $\left[\mathrm{Mn}(\mathrm{tpy})_{2}\right]^{2+}$ at $-1.52,-1.86$ and $-2.37 \mathrm{~V}$ (Table 4) [26]. The manganese centre remains high-spin $\left(S_{\mathrm{Mn}}=5 / 2\right)$ throughout this series. The neutral complex $\mathrm{Mn}^{\mathrm{II}}\left(\mathrm{tpy} \cdot{ }^{-}\right)_{2}$ has been structurally and magnetically characterized. Its $S=3 / 2$ ground state is attained 
via antiferromagnetic coupling of the five unpaired electrons of the $\mathrm{Mn}^{\mathrm{II}}$ ion with the unpaired spins of the two tpy. ${ }^{-}$ligands [26].

A comparison of the structural, optical, electrochemical and magnetic data with those of $\left[\mathrm{Mn}(\mathrm{ddpd})_{2}\right]^{n+}$ complexes must await the preparation of the respective manganese ddpd complexes.

\section{9. $m e r-\left[\mathrm{Cr}(\mathrm{ddpd})_{2}\right]^{3+}$, mer- $\mathrm{CrCl}_{3}(\mathrm{ddpd})\left[\mathrm{d}^{3}\right]$ and $m e r-\left[\mathrm{Cr}(\mathrm{ddpd})_{2}\right]^{2+}\left[\mathrm{d}^{4}\right]$}

The heteroleptic complexes $\mathrm{CrCl}_{3}(\mathrm{tpy})$ and mer-CrCl$(\mathrm{ddpd})$ are easily prepared from $\mathrm{CrCl}_{3}(\mathrm{thf})_{3}$ or $\mathrm{CrCl}_{3} \times 6 \mathrm{H}_{2} \mathrm{O}$ and the respective pincer ligand (Figure 9a,b) [71,126]. Recently, Hauser and Piguet realized heteroleptic $\left[\mathrm{Cr}(\mathrm{tpy})\left(\mathrm{L}^{\prime}\right)\right]^{3+}$ complexes starting from $\mathrm{CrCl}_{3}(\mathrm{tpy})$ via $\mathrm{Cr}(\mathrm{tpy})\left(\mathrm{CF}_{3} \mathrm{SO}_{3}\right)_{3}$ and further tridentate polypyridine ligands L' [126]. The homoleptic chromium(III) complexes $\left[\mathrm{Cr}(\mathrm{tpy})_{2}\right]^{3+}$ and $\left[\mathrm{Cr}(\mathrm{ddpd})_{2}\right]^{3+}$ are best prepared from more reactive chromium(II) salts such as $\mathrm{Cr}\left(\mathrm{CF}_{3} \mathrm{SO}_{3}\right)_{2}$ or $\mathrm{CrCl}_{2}$ and the respective tridentate ligands, followed by (aerial) oxidation (Figure 9c,d) [50,71]. Surprisingly, $\left[\mathrm{Cr}(\mathrm{tpy})_{2}\right]^{3+}$ is quite labile in alkaline aqueous solution, presumably yielding to tpy displacement and $\left[\mathrm{Cr}(\mathrm{tpy})(\mathrm{OH})_{x}\right]_{n}{ }^{(3-x) n}$ species [71]. On the contrary, $\left[\mathrm{Cr}(\mathrm{ddpd})_{2}\right]^{3+}$ is substitutionally inert under these conditions-even under irradiation [50].

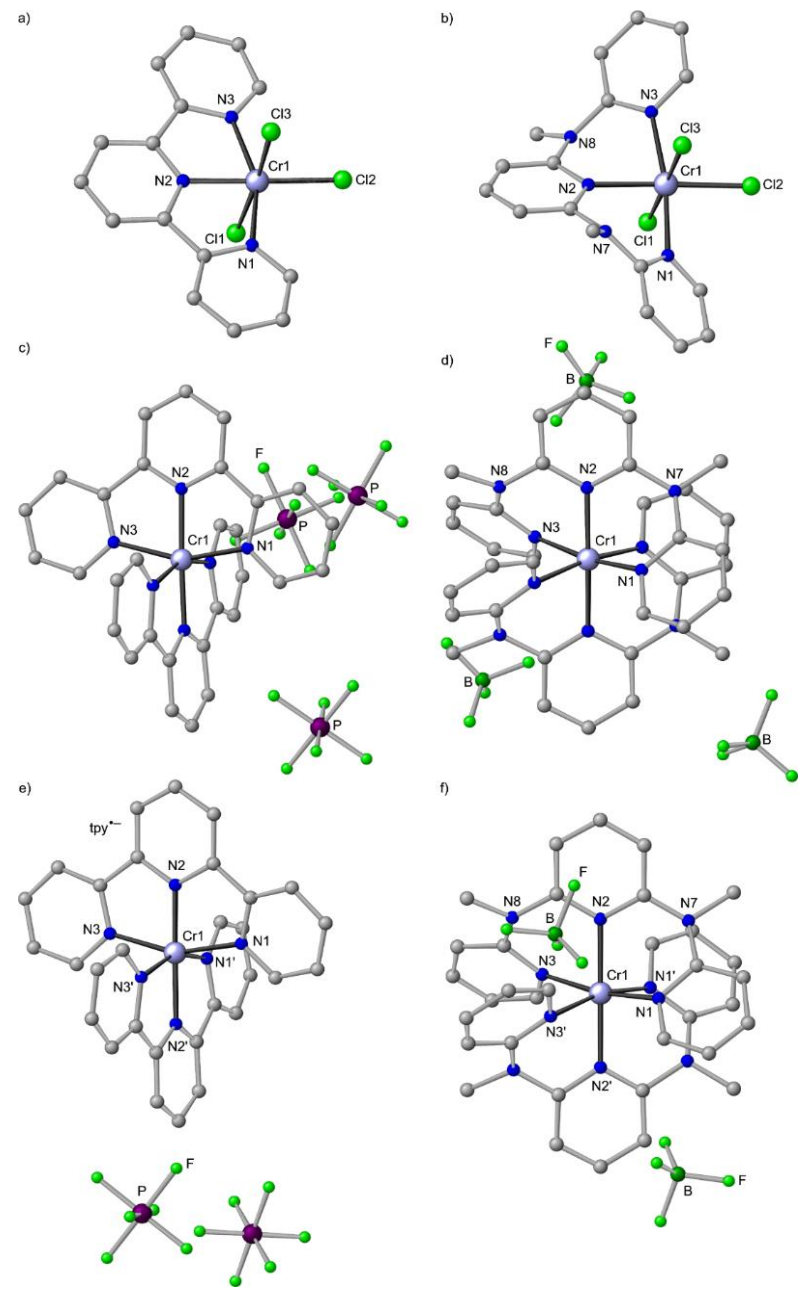

Figure 9. Molecular structures of (a) $\mathrm{CrCl}_{3}(\mathrm{tpy}) \times \mathrm{DMSO}$ [127], (b) mer- $\mathrm{CrCl}_{3}$ (ddpd) [126], (c) [Cr(tpy) $\left.)_{2}\right]$ $\left[\mathrm{PF}_{6}\right]_{3} \times 2.5 \mathrm{CH}_{3} \mathrm{CN}[126],(\mathbf{d})$ mer- $\left[\mathrm{Cr}(\mathrm{ddpd})_{2}\right]\left[\mathrm{BF}_{4}\right]_{3} \times 3 \mathrm{CH}_{3} \mathrm{CN}$ [50] and (e) $\left[\mathrm{Cr}(\mathrm{tpy})_{2}\right]\left[\mathrm{PF}_{6}\right]_{2} \times 2 \mathrm{CH}_{3} \mathrm{CN}$ [27] and (f) mer-[Cr(ddpd $\left.)_{2}\right]\left[\mathrm{BF}_{4}\right]_{2} \times 2 \mathrm{CH}_{3} \mathrm{CN}$ in the solid state; hydrogen atoms and solvent molecules omitted. Atom numbering unified for clarity. In the dications two different tridentate ligands are observed labelled as $\mathrm{N} 1 / \mathrm{N} 2 / \mathrm{N} 3$ and $\mathrm{N}^{\prime}$ / $\mathrm{N} 2^{\prime} / \mathrm{N}^{\prime}$. 
The room temperature magnetic susceptibility of $\left[\mathrm{Cr}(\operatorname{tpy})_{2}\right]^{3+}$ and $\left[\mathrm{Cr}(\mathrm{ddpd})_{2}\right]^{3+}$ amounts to $\chi \mathrm{T}=1.921$ and $1.838 \mathrm{~cm}^{3} \mathrm{~K} \mathrm{~mol}^{-1}$, respectively (Table 5), confirming the expected $\left(\mathrm{t}_{2 \mathrm{~g}}\right)^{3}$ electron configuration $\left({ }^{4} \mathrm{~A}_{2}\right.$ ground state) for both complexes [27,50]. The magnetic moment of $\left[\mathrm{Cr}(\mathrm{ddpd})_{2}\right]$ $\left[\mathrm{BF}_{4}\right]_{3}$ is temperature-independent down to $40 \mathrm{~K}$. At $2 \mathrm{~K}$, $\chi \mathrm{T}$ has dropped to $1.788 \mathrm{~cm}^{3} \mathrm{~K} \mathrm{~mol}^{-1}$, suggesting weak zero-field splitting or weak intermolecular antiferromagetic interactions.

The first spin-allowed ligand field transition ${ }^{4} \mathrm{~A}_{2} \rightarrow{ }^{4} \mathrm{~T}_{2}$ of $\left[\mathrm{Cr}(\mathrm{tpy})_{2}\right]^{3+}$ appears at $533 \mathrm{~nm}$ [126], that of $\left[\mathrm{Cr}(\mathrm{ddpd})_{2}\right]^{3+}$ at $435 \mathrm{~nm}$ [50]. These data imply a much larger ligand field splitting $\Delta_{\mathrm{o}}$ in the latter complex by more than $4200 \mathrm{~cm}^{-1}$.

The non-innocent tpy ligand accounts for the ligand-based reduction chemistry of $\left[\mathrm{Cr}^{\mathrm{III}}(\mathrm{tpy})_{2}\right]^{3+}$ giving $\left[\mathrm{Cr}^{\mathrm{III}}\left(\text { tpy } \cdot{ }^{-}\right)(\mathrm{tpy})\right]^{2+},\left[\mathrm{Cr}^{\mathrm{III}}\left(\mathrm{tpy}^{-}{ }^{-}\right)_{2}\right]^{+}$and $\left[\mathrm{Cr}^{\mathrm{III}}\left(\mathrm{tpy}^{2-}\right)\left(\mathrm{tpy}^{-}{ }^{-}\right)\right]^{0}$, respectively, as demonstrated by Wieghardt and co-workers [27]. On the other hand, $\left[\mathrm{Cr}(\mathrm{ddpd})_{2}\right]^{3+}$ is reversibly reduced to the reactive $\mathrm{d}^{4}$ chromium(II) complex $\left[\mathrm{Cr}(\mathrm{ddpd})_{2}\right]^{2+}$ at $-1.11 \mathrm{~V}$ and irreversibly at the ddpd ligand at $-1.94 \mathrm{~V}$ (Table 4) [50]. The ddpd/ddpd ${ }^{+}$oxidation is observed at $+1.71 \mathrm{~V}$, at much higher potential than the oxidation of the ddpd ligand in the dicationic $\left[\mathrm{Zn}(\operatorname{tpy})_{2}\right]^{2+}$ complex $(+1.17 \mathrm{~V}$, Table 4$)$ due to the +3 charge of $\left[\mathrm{Cr}(\mathrm{ddpd})_{2}\right]^{3+}[50]$. Both the substitutional lability and the electronic structure of the reduced species $\left[\mathrm{Cr}(\mathrm{tpy})_{2}\right]^{3-n}(n=1-3)$ are consequences of the $\pi$-accepting character and redox non-innocence of terpyridine. In contrast, ddpd is much more electron donating, thus preventing nucleophilic attack of hydroxide ions at the chromium(III) centre in $\left[\mathrm{Cr}(\mathrm{ddpd})_{2}\right]^{3+}$.

Single crystals of the green labile, oxygen and moisture sensitive chromium(II) complex $\left[\mathrm{Cr}(\mathrm{ddpd})_{2}\right]\left[\mathrm{BF}_{4}\right]_{2} \times 2 \mathrm{CH}_{3} \mathrm{CN}$ could be obtained from $\left[\mathrm{Cr}\left(\mathrm{NCCH}_{3}\right)_{4}\right]\left[\mathrm{BF}_{4}\right]_{2}[128]$ and ddpd (Table 1). The magnetic susceptibility data (in solution) confirm the high-spin state at room temperature (Table 5). According to DFT calculations on the $\left[\mathrm{Cr}(\mathrm{ddpd})_{2}\right]^{2+}$ dication, the high-spin $\mathrm{d}^{4}$-chromium(II) complex is Jahn-Teller distorted $[59,129]$ with $\mathrm{Cr}-\mathrm{N} 2=2.052, \mathrm{Cr}-\mathrm{N} 1=\mathrm{Cr}-\mathrm{N} 3=2.110$ and $\mathrm{Cr}-\mathrm{N} 2{ }^{\prime}=2.117$, $\mathrm{Cr}-\mathrm{N1}^{\prime}=2.311$ and $\mathrm{Cr}-\mathrm{N} 3^{\prime}=2.312 \AA$. A similar, yet less pronounced elongated octahedron is observed with $\mathrm{Cr}-\mathrm{N} 2=2.064(9), \mathrm{Cr}-\mathrm{N} 1=\mathrm{Cr}-\mathrm{N} 3=2.089(6)$ and $\mathrm{Cr}-\mathrm{N} 2^{\prime}=2.070(11), \mathrm{Cr}-\mathrm{N} 1^{\prime}=\mathrm{Cr}-\mathrm{N} 3^{\prime}=2.117(7)$ $\AA$ in the crystalline state at $263 \mathrm{~K}$ (Table 1). At $263 \mathrm{~K}$, this Jahn-Teller distortion is probably dynamic, as the difference between the short and long equatorial bonds $\left(\Delta d_{\mathrm{sl}}=0.028 \AA\right)$ is less than that in $\left[\mathrm{Cr}\left(\mathrm{NCCH}_{3}\right)_{6}\right]\left[\mathrm{BPh}_{4}\right]_{2}$ at $110 \mathrm{~K}(\mathrm{Cr}-\mathrm{N}=2.0655,2.0918$ and $2.4231 \AA$ ) [130]. The electronic and geometric situation is similar to that of the $\mathrm{d}^{9} \mathrm{Jahn}$-Teller complex $\left[\mathrm{Cu}(\mathrm{ddpd})_{2}\right]\left[\mathrm{BF}_{4}\right]_{2} \times 2 \mathrm{CH}_{3} \mathrm{CN}[60]$ at $263 \mathrm{~K}$ (Table 1; vide supra).

In contrast, the tpy analogue $\left[\mathrm{Cr}{ }^{\mathrm{III}}\left(\mathrm{tpy} \cdot \cdot^{-}\right)(\mathrm{tpy})\right]\left[\mathrm{PF}_{6}\right]_{2} \times 2 \mathrm{CH}_{3} \mathrm{CN}$ features two different tpy ligands, assigned to tpy $\cdot^{-}$and tpy but no pronounced tetragonal elongation at $100 \mathrm{~K}$ (tpy: $\mathrm{Cr}-\mathrm{N} 2=1.976 \AA$; $\mathrm{Cr}-\mathrm{N} 1 / 3=2.056 \AA$; tpy $\cdot^{-}: \mathrm{Cr}-\mathrm{N} 2=1.916 \AA ; \mathrm{Cr}-\mathrm{N} 1 / 3=2.042 \AA ; \Delta d_{\mathrm{sl}}=0.014 \AA$; Table 2) [27]. Again, the different electronic description of $\left[\mathrm{Cr}(\mathrm{ddpd})_{2}\right]^{2+}$ and $\left[\mathrm{Cr}(\mathrm{tpy})_{2}\right]^{2+}$ is rooted in the different electron accepting nature of the oligopyridine ligands.

The neutral complex $\left[\mathrm{Cr}(\mathrm{tpy})_{2}\right]^{0}$ is conveniently prepared from $\mathrm{Cr}(\mathrm{CO})_{6}$ and tpy [27]. No heteroleptic intermediate complex $\mathrm{Cr}(\mathrm{CO})_{3}($ tpy) has been reported, probably due to the required meridional configuration of $\mathrm{Cr}(\mathrm{CO})_{3}$ (tpy) with trans positioned $\mathrm{CO}$ ligands, in contrast to the stable $\mathrm{fac}-\mathrm{Cr}(\mathrm{CO})_{3}(\mathrm{py})_{3}$ complex already prepared by Hieber [131,132]. Furthermore, tpy might already acquire $\pi$ electron density from the low-valent chromium centre in the intermediate complex $\mathrm{Cr}(\mathrm{CO})_{3}\left(\right.$ tpy), which further labilizes the $\mathrm{Cr}-\mathrm{CO}$ bond. In contrast, neutral $\left[\mathrm{Cr}(\mathrm{ddpd})_{2}\right]^{0}$ could not be obtained from $\mathrm{Cr}(\mathrm{CO})_{6}$ and ddpd even under forcing conditions (refluxing mesitylene, b.p. $165^{\circ} \mathrm{C}$ ). This substitution reaction arrests at the heteroleptic tricarbonyl complex $f a c-\mathrm{Cr}(\mathrm{CO})_{3}(\mathrm{ddpd})$. The $\tilde{v}_{\mathrm{CO}}$ IR data of this chromium(0) complex (1891 (s), 1775 (s), 1740 (s) $\mathrm{cm}^{-1}$ ) suggest a facial ligand arrangement, which is enabled by the flexible ddpd ligand. The ũ $\mathrm{CO}$ data are comparable to those of $f a c-\mathrm{Cr}(\mathrm{CO})_{3}\left[\mathrm{P}(2-\mathrm{py})_{3}\right]$ with three perfectly identical monodentate pyridine ligands (1901 (s), 1777 (br) $\mathrm{cm}^{-1}$ ) [133] and to $f a c-\mathrm{Cr}(\mathrm{CO})_{3}\left[\mathrm{HN}(2-\mathrm{py})_{2}\right]$ (4-pic) with strongly dissimilar pyridine donor ligands (1893 (s), 1780 (s), 1720 (s) $\mathrm{cm}^{-1}$ ) [134] (cf. Scheme 4 for cis-fac isomers of homoleptic complexes). The similar intensities of the three $\tilde{u}_{\mathrm{CO}}$ bands also support the facial isomer instead of a mer-isomer, which should show a less intense $\mathrm{A}_{1}$ absorption band. In accordance with this 
assignment, DFT calculations find the fac-isomer more stable than the $m e r$-isomer by $54 \mathrm{~kJ} \mathrm{~mol}^{-1}$ (Supplementary Materials). Furthermore, the electron donating character of ddpd stabilize the trans $\mathrm{Cr}-\mathrm{CO}$ bonds in $\mathrm{fac}-\mathrm{Cr}(\mathrm{CO})_{3}(\mathrm{ddpd})$ and the three $\mathrm{CO}$ ligands resist further substitution by ddpd [135].

2,2'-Bipyridine (bpy), 1,10-phenanthroline (phen), tpy and ddpd are strong field ligands and consequently, the spin-flip states ${ }^{2} \mathrm{E} /{ }^{2} \mathrm{~T}_{1}$ are lower in energy than the ${ }^{4} \mathrm{~T}_{2}$ ligand field state. Indeed, ${ }^{2} \mathrm{E}$ phosphorescence is observed for the corresponding homoleptic chromium(III) complexes at 727, 730, 770 and $775 \mathrm{~nm}$, respectively (Figure 10) [50,136]. However, the photoluminescence quantum yields of the three former complexes are below $0.15 \%$ hampering useful optical applications. The very low quantum yield of $\left[\mathrm{Cr}(\mathrm{tpy})_{2}\right]^{3+}(<0.00089 \%)$ has been accounted for by the strong deviation from octahedral symmetry $(S(\mathrm{OC}-6)>2.5$, Table 2$)$ and consequently a comparably small ligand field splitting with poor chromium-ligand orbital overlap. The small ligand field splitting places the detrimental ${ }^{4} \mathrm{~T}_{2}$ ligand field state close in energy to the luminescent ${ }^{2} \mathrm{E}$ state allowing for thermal back-intersystem crossing and hence non-radiative deactivation. Substituent effects at the $4^{\prime}$-position of tpy slightly improve the brightness of the luminescence of $\left[\mathrm{Cr}(\mathrm{R} \text {-tpy })_{2}\right]^{3+}(\mathrm{R}=$ $p-\mathrm{Me}-\mathrm{C}_{6} \mathrm{H}_{4}, p-\mathrm{MeO}-\mathrm{C}_{6} \mathrm{H}_{4}$ ) by increasing both the absorbance in the visible spectral region and the quantum yield by a factor of 4.3 relative to unsubstituted $\left[\mathrm{Cr}(\operatorname{tpy})_{2}\right]^{3+}[137]$. On the other hand, the $\left[\mathrm{Cr}(\mathrm{ddpd})_{2}\right]^{3+}$ complex with a geometry close to octahedral $(S(\mathrm{OC}-6)<0.5$, Table 1$)$ enables record luminescence quantum yields of $\phi=12 \%$ and $11 \%$ in $\mathrm{CH}_{3} \mathrm{CN}$ and $\mathrm{H}_{2} \mathrm{O}$, respectively [50,53]. These values have been further boosted by the combined action of ligand (Scheme 2 ) and solvent deuteration to $\phi=30 \%$ and $22 \%$ in $\mathrm{D}_{2} \mathrm{O}$ and $\mathrm{CD}_{3} \mathrm{CN}$, respectively $[42,53]$. These measures reduce the multiphonon relaxation via $\mathrm{CH}$ and $\mathrm{OH}$ oscillators and consequently increase the luminescence quantum yield $[42,53]$. Concomitant with the very high quantum yields, the lifetime of the doublet excited state increases to up to $2.3 \mathrm{~ms}$ [42]. Similarly, deuteration of the $\mathrm{NH}$ groups of the analogous $\left[\mathrm{Cr}\left(\mathrm{H}_{2} \text { tpda }\right)_{2}\right]^{3+}$ complex increases the luminescence quantum yield from $8.8 \%$ to $12.0 \%$ in $\mathrm{CH}_{3} \mathrm{CN}$ due to the removal of the NH oscillators [138]. The high quantum yields and excited state lifetimes of $\left[\mathrm{Cr}(\mathrm{ddpd})_{2}\right]^{3+}$ complexes led to their description as "molecular rubies" [42,50,53].

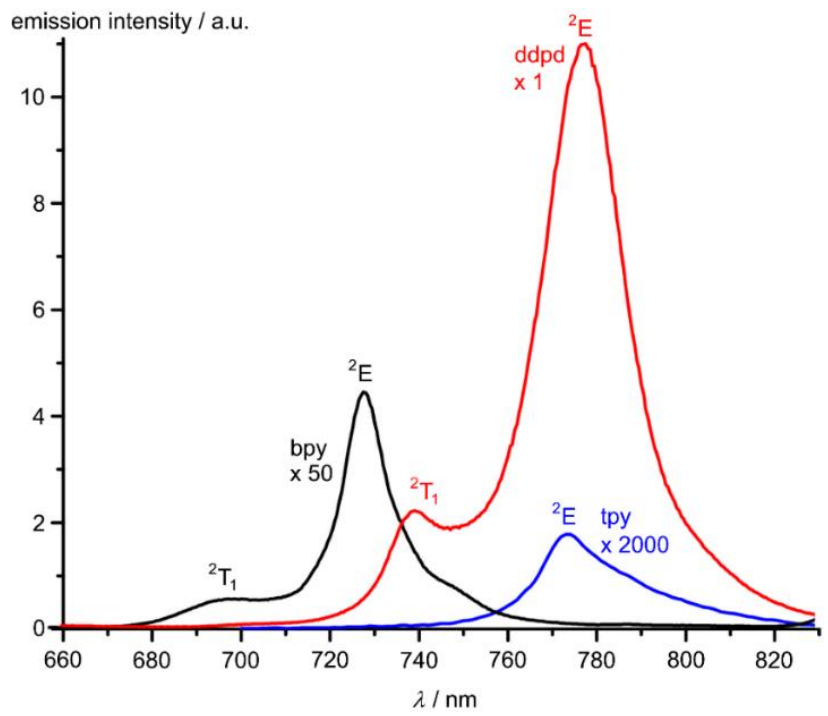

Figure 10. Luminescence spectra of $\left[\mathrm{Cr}(\mathrm{bpy})_{3}\right]\left[\mathrm{PF}_{6}\right]_{3}$ (black) $\left[\mathrm{Cr}(\mathrm{tpy})_{2}\right]\left[\mathrm{PF}_{6}\right]_{3}$ (blue) and $\left[\mathrm{Cr}(\mathrm{ddpd})_{2}\right]\left[\mathrm{BF}_{4}\right]_{3}$ (red) in $\mathrm{CH}_{3} \mathrm{CN}$. The bands are labelled with the respective term symbols. Please note the very different scaling factors.

The reactivity of the excited states of $\left[\mathrm{Cr}(\mathrm{ddpd})_{2}\right]^{3+}$ and $\left[\mathrm{Cr}(\mathrm{tpy})_{2}\right]^{3+} /\left[\mathrm{Cr}(\mathrm{bpy})_{3}\right]^{3+}$ differ as well [139]. As the metal-centred $\left[\mathrm{Cr}(\mathrm{ddpd})_{2}\right]^{3+/ 2+}$ redox process occurs at a much more cathodic potential than the tpy-based redox process of $\left[\mathrm{Cr}(\operatorname{tpy})_{2}\right]^{3+/ 2+}(\mathrm{Table} 4)$, its oxidative power in the excited state with $0.49 \mathrm{~V}$ is much lower than that of $\left[\mathrm{Cr}(\mathrm{tpy})_{2}\right]^{3+/ 2+}$ with $1.08 \mathrm{~V}$ [50]. Indeed, $\left[\mathrm{Cr}\left(4^{\prime}-\mathrm{Tol}-\mathrm{tpy}\right)_{2}\right]^{3+}$ 
photooxidizes the DNA base guanine and hence can cleave DNA [140], while $\left[\mathrm{Cr}(\mathrm{ddpd})_{2}\right]^{3+}$ does not damage DNA via guanine photooxidation [50]. The organic photoredox chemistry, using strongly oxidizing $\left[\mathrm{Cr}(\mathrm{phen})_{3}\right]^{3+}$ sensitizers, has recently been advanced by Shores and Ferreira [141-143]. On the other hand, the very long lifetime and the non-oxidizing character of the ${ }^{2} \mathrm{E}$ state of $\left[\mathrm{Cr}(\mathrm{ddpd})_{2}\right]^{3+}$ enables the efficient and selective formation of singlet oxygen via energy transfer to ${ }^{3} \mathrm{O}_{2}$ [139]. The thus generated ${ }^{1} \mathrm{O}_{2}$ has been successfully utilized for visible-light-induced oxidative $\mathrm{C}-\mathrm{H}$ bond functionalization of tertiary amines [139]. The luminescence quenching of the stable and highly luminescent $\left[\mathrm{Cr}(\mathrm{ddpd})_{2}\right]^{3+}$ complex by triplet oxygen can be further elaborated into optical oxygen sensors [53].

Furthermore, optical sensing of temperature has been realized with dissolved molecular $\left[\mathrm{Cr}(\mathrm{ddpd})_{2}\right]^{3+}$ complexes and with $\left[\mathrm{Cr}(\mathrm{ddpd})_{2}\right]^{3+}$ enclosed in polystyrene nanoparticles or micelles [144]. Exploiting the thermal equilibration of the long-lived emissive ${ }^{2} \mathrm{E}$ and ${ }^{2} \mathrm{~T}_{1}$ states allows using the dual emitter $\left[\mathrm{Cr}(\mathrm{ddpd})_{2}\right]^{3+}$ as self-referencing dye (Figure 10) [144]. Moreover, the pressure-dependent energy shift of the ${ }^{2} \mathrm{E}$ emission band has been utilized for optical pressure detection both in the solid state and in solution. The pressure sensitivity of $\left[\mathrm{Cr}(\mathrm{ddpd})_{2}\right]\left[\mathrm{BF}_{4}\right]_{3}$ $\left({ }^{2} \mathrm{E}\right.$ state: $\left.-14.1 \mathrm{~cm}^{-1} \mathrm{kbar}^{-1}\right)$ is much higher than that of the standard pressure calibrant $\mathrm{Al}_{2} \mathrm{O}_{3}: \mathrm{Cr}$ (ruby, $-0.7 \mathrm{~cm}^{-1} \mathrm{kbar}^{-1}$ ), enabling highly sensitive future applications [145,146]. Interestingly, the pressure shift of the well resolved ${ }^{2} \mathrm{~T}_{1}$ emission band of $\left[\mathrm{Cr}(\mathrm{ddpd})_{2}\right]^{3+}$ differs with $-7.7 \mathrm{~cm}^{-1}$ $\mathrm{kbar}^{-1}$ significantly from the ${ }^{2} \mathrm{E}$ shift. This phenomenon has been ascribed to the distinct effects of pressure-induced angular distortions on the ${ }^{2} \mathrm{E}$ and ${ }^{2} \mathrm{~T}_{1}$ spin-flip states of chromium(III) ions in $\left[\mathrm{Cr}(\mathrm{ddpd})_{2}\right]^{3+}[145]$.

Clearly, the different coordinating ability and electron accepting nature of tpy and ddpd translate into very complementary ground state (substitution, redox) and excited state reactivity (luminescence, electron transfer, energy transfer) of their homoleptic chromium(III) complexes $\left[\mathrm{Cr}(\mathrm{ddpd})_{2}\right]^{3+}$ and $\left[\mathrm{Cr}(\mathrm{tpy})_{2}\right]^{3+}$.

\section{0. $c i s-f a c-\left[\mathrm{V}(\mathrm{ddpd})_{2}\right]^{3+}$ and $m e r-\mathrm{VCl}_{3}(\mathrm{ddpd})\left[\mathrm{d}^{2}\right]$}

The solution chemistry of $\mathrm{VCl}_{3}$ and pyridine is complicated due to complex equilibria and accompanying redox chemistry [147]. Literature reports concerning vanadium(III) complexes with terpyridine are very scarce. The brown heteroleptic complex $\mathrm{VCl}_{3}(\mathrm{tpy})$ has been prepared from $\mathrm{VCl}_{3}$ and tpy $[80,148,149]$. Similarly, yellow mer- $\mathrm{VCl}_{3}(\mathrm{ddpd})$ is obtained from $\mathrm{VCl}_{3}(\mathrm{thf})_{3}[150]$ and ddpd displaying an LMCT absorption band at $455 \mathrm{~nm}$ (Figure S3). A related $\mathrm{VCl}_{3}$ complex $\mathrm{VCl}_{3}(\mathrm{~L}$ ) with $\mathrm{L}=2,6$-bis(3,5-diphenylpyrazol-1-ylmethyl)pyridine as tridentate nitrogen donor ligand forming 6-membered chelate rings had been reported as pre-catalyst for ethylene polymerization [151]. Yet, structural data of $\mathrm{VCl}_{3}(\mathrm{tpy})$ and $\mathrm{VCl}_{3}(\mathrm{~L})$ are lacking. A few solid-state structures of $\mathrm{VCl}_{3}(\mathrm{bimpy})$ (bimpy $=2,6$-bis(imino)pyridine) ligands forming five-membered chelate rings) have been reported and these complexes have been employed in radical polymerization catalysis [152]. $\mathrm{VCl}_{3}(\mathrm{ddpd})$ crystallised in the monoclinic space group $P 2_{1} / \mathrm{n}$ as a monomeric complex with meridional ddpd coordination (Figure 11a), isostructural to $m e r-\mathrm{CrCl}_{3}(\mathrm{ddpd})$ [126]. The magnetic susceptibility of $\mathrm{VCl}_{3}$ (tpy) $\left(\chi \mathrm{T}=0.744 \mathrm{~cm}^{-1} \mathrm{~K} \mathrm{~mol}^{-1}\right.$ at $\left.290 \mathrm{~K}\right)$ and $m e r-\mathrm{VCl}_{3}$ (ddpd) $\left(\chi \mathrm{T}=0.879 \mathrm{~cm}^{-1} \mathrm{~K} \mathrm{~mol}^{-1}\right.$ at $290 \mathrm{~K}$; Figure S4) is less than expected for a $\left(\mathrm{t}_{2 \mathrm{~g}}\right)^{2}$ electron configuration $\left({ }^{3} \mathrm{~T}_{1}\right.$ ground state) and has been ascribed to the splitting of the ${ }^{3} \mathrm{~T}_{1}$ ground state by the ligand field [148]. 
a)

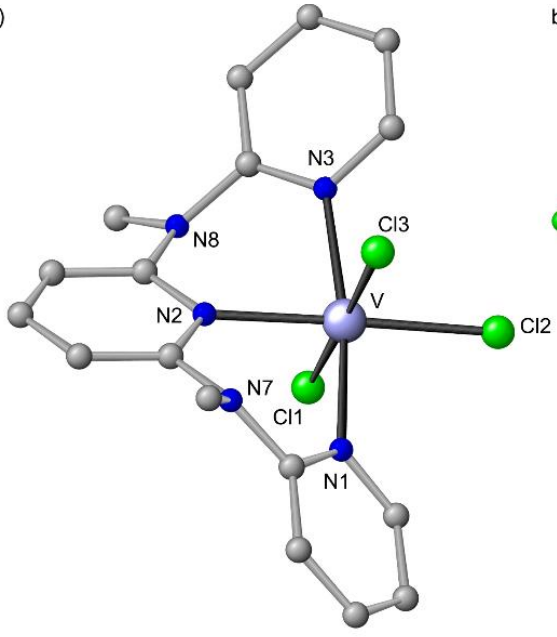

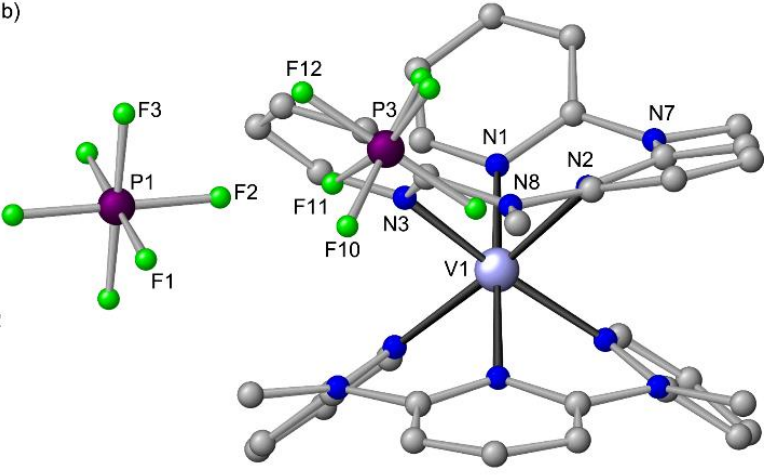

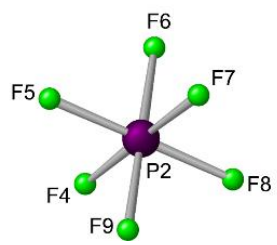

Figure 11. Molecular structures of (a) $m e r-\mathrm{VCl}_{3}(\mathrm{ddpd})$ and (b) $c i s-f a c-\left[\mathrm{V}(\mathrm{ddpd})_{2}\right]\left[\mathrm{PF}_{6}\right]_{3}$ in the solid state; hydrogen atoms and solvent molecules omitted. Atom numbering unified for clarity.

In the presence of three equivalents $\mathrm{Ag}\left[\mathrm{CF}_{3} \mathrm{SO}_{3}\right]$ and tpy, $\mathrm{VCl}_{3}$ (tpy) presumably forms $\left[\mathrm{V}(\text { tpy })_{2}\right]^{3+}$ initially. However, this vanadium(III) complex readily disproportionates to $\left[\mathrm{V}(\mathrm{tpy})_{2}\right]^{2+}$ and a $\left[\mathrm{V}^{\mathrm{IV}} \mathrm{O}\right]^{2+}$ species, with the oxygen atom likely stemming from traces of water [80]. [V(tpy $\left.)_{2}\right] \mathrm{I}_{2}$ had been prepared from $\mathrm{VSO}_{4}$, tpy and ion exchange with $\mathrm{KI}$. Its magnetic moment fits to a $\mathrm{d}^{3}$ electron configuration (Table 5) [90]. The dicationic complex $\left[\mathrm{V}(\mathrm{tpy})_{2}\right]^{2+}$ exhibits absorption bands at $\lambda=767$ and $402 \mathrm{~nm}$ [153]. The intensity of the low-energy band suggests charge transfer character. Two electronic descriptions of the ground state are conceivable, namely $\left[\mathrm{V}^{\mathrm{II}}(\mathrm{tpy})_{2}\right]^{2+}$ or $\left[\mathrm{V}^{\mathrm{III}}\left(\mathrm{tpy}^{-}{ }^{-}\right)(\mathrm{tpy})\right]^{2+}$ with MLCT or LMCT bands, respectively. However, the electronic structure of $\left[\mathrm{V}(\mathrm{tpy})_{2}\right]^{2+}$ has not yet been determined experimentally.

Oxidation of green $\left[\mathrm{V}(\mathrm{tpy})_{2}\right]^{2+}$ occurs at $-0.09 \mathrm{~V}$ (vs. ferrocene) [80] and is reported as quasireversible, again pointing to disproportionation of the initially formed $\left[\mathrm{V}(\mathrm{tpy})_{2}\right]^{3+}$ complex (Table 4). Hence, the vanadium(III) complex $\left[\mathrm{V}(\mathrm{tpy})_{2}\right]^{3+}$ has not yet been isolated.

In the presence of $\mathrm{Tl}_{[}\left[\mathrm{PF}_{6}\right]$ as chloride acceptor, $m e r-\mathrm{VCl}_{3}(\mathrm{ddpd})$ and ddpd yields $\left[\mathrm{V}(\mathrm{ddpd})_{2}\right]^{3+}$ without any signs for disproportionation in $\mathrm{V}^{\mathrm{II}}$ and $\left[\mathrm{V}^{\mathrm{IV}} \mathrm{O}\right]^{2+}$. In principle, this synthetic procedure could also allow for heteroleptic vanadium(III) complexes with ddpd. The cis-fac stereoisomer of $\left[\mathrm{V}(\mathrm{ddpd})_{2}\right]^{3+}$ has been crystallographically characterized (Figure $11 \mathrm{~b}$ ), providing first structural data of a homoleptic polypyridine vanadium(III) complex. Obviously, the electron-rich ddpd ligand stabilizes electron-poor $\mathrm{d}^{2}-\mathrm{V}^{\mathrm{III}}$ complexes in contrast to the $\pi$-accepting tpy ligand.

Ligand substitution of $\left.\mathrm{V}^{6} \eta^{6}-\mathrm{C}_{6} \mathrm{H}_{6}\right)_{2}, \mathrm{~V}(\mathrm{CO})_{4}$ (dppe) or $\mathrm{K}\left[\mathrm{V}(\mathrm{CO})_{6}\right]$ with tpy (dppe = 1,2-bis (diphenylphosphano)ethane) [154], reduction of [V(tpy) $]_{2} \mathrm{I}_{2}$ with $\mathrm{Mg}$ in $\mathrm{DMF}$ or $\mathrm{LiAlH}_{4}$ in dioxane [90] or sodium amalgam reduction of $\mathrm{VCl}_{3}$ in the presence of tpy yields the black, neutral complex $\left[\mathrm{V}(\mathrm{tpy})_{2}\right]^{0}[155]$. According to single crystal X-ray diffraction and spectroscopic data, $\left[\mathrm{V}(\mathrm{tpy})_{2}\right]^{0}$ features a $\left[\mathrm{V}^{\mathrm{IV}}\left(\mathrm{tpy}^{2-}\right)_{2}\right]^{0}$ electronic structure with an unpaired electron localized at the vanadium ion $(S=1 / 2)[90,154,155]$. These data again illustrate the complementary nature of tpy and ddpd, with tpy stabilizing reduced, electron-rich vanadium species by internal redox reactions and ddpd stabilizing electron-poor vanadium(III) complexes.

\section{Experimental Section}

X-ray diffraction of ddpd, [H-ddpd] $\left[\mathrm{CF}_{3} \mathrm{SO}_{3}\right],\left[\mathrm{Co}(\mathrm{ddpd})_{2}\right]\left[\mathrm{BF}_{4}\right]_{3} \times 3 \mathrm{CH}_{3} \mathrm{CN}$, [Fe(ddpd $\left.)_{2}\right] \mathrm{Br}_{2} \times$ $2 \mathrm{CH}_{3} \mathrm{CN}, \mathrm{VCl}_{3}(\mathrm{ddpd})$, mer- $\left[\mathrm{Cr}(\mathrm{ddpd})_{2}\right]\left[\mathrm{BF}_{4}\right]_{2} \times 2 \mathrm{CH}_{3} \mathrm{CN}$ and cis-fac-[V(ddpd $\left.)_{2}\right]\left[\mathrm{PF}_{6}\right]_{3} \times 3 \mathrm{CH}_{3} \mathrm{CN}$ : 
Intensity data were collected with a STOE IPDS-2T diffractometer with an Oxford cooling system using Mo-K $\alpha$ radiation $(\lambda=0.71073 \AA)$. The diffraction frames were integrated using the Bruker SMART software package [156] and most were corrected for absorption with MULABS [157] of the PLATON software package [158]. The structures were solved by direct methods and refined by the full-matrix method based on $F^{2}$ using the SHELXL software package $[159,160]$. All non-hydrogen atoms were refined anisotropically, while the positions of all hydrogen atoms were generated with appropriate geometric constraints and allowed to ride on their respective parent atoms with fixed isotropic thermal parameters. Only, the non-hydrogen atoms of co-crystallized acetonitrile in mer-[Fe(ddpd $\left.)_{2}\right] \mathrm{Br}_{2} \times 2 \mathrm{CH}_{3} \mathrm{CN}$ have been refined isotropically.

Crystallographic data for the structure reported in this paper have been deposited with the Cambridge Crystallographic Data Centre as supplementary publication no CCDC-1832949 (ddpd), $\left.1832948\left([\mathrm{H}-\mathrm{ddpd}]\left[\mathrm{CF}_{3} \mathrm{SO}_{3}\right]\right), 1832951\left(\mathrm{mer}-\left[\mathrm{Co}(\mathrm{ddpd})_{2}\right]\left[\mathrm{BF}_{4}\right]_{3} \times 3 \mathrm{CH}_{3} \mathrm{CN}\right), 1832950(\text { mer-[Fe(ddpd })_{2}\right]$ $\left.\mathrm{Br}_{2} \times 2 \mathrm{CH}_{3} \mathrm{CN}\right), 1844780\left(\right.$ mer- $\left.\left[\mathrm{Cr}(\mathrm{ddpd})_{2}\right]\left[\mathrm{BF}_{4}\right]_{2} \times 2 \mathrm{CH}_{3} \mathrm{CN}\right), 1840435\left(\mathrm{VCl}_{3}(\mathrm{ddpd})\right)$ and 1840434 (cis-fac-[V(ddpd $\left.\left.)_{2}\right]\left[\mathrm{PF}_{6}\right]_{3} \times 3 \mathrm{CH}_{3} \mathrm{CN}\right)$. Copies of the data can be obtained free of charge upon application to CCDC, 12 Union Road, Cambridge CB2 1EZ, U.K. [fax (0.44) 1223-336-033; e-mail deposit@ccdc.cam.ac.uk].

Crystallographic Data of ddpd: $\mathrm{C}_{17} \mathrm{H}_{177} \mathrm{~N}_{5}$ (291.35); orthorhombic; Pnma; $a=11.772(2) \AA$, $b=18.989(4) \AA, c=6.7282(14) \AA, V=1504.0(5) \AA^{3} ; Z=4$; density, calcd. $=1.287 \mathrm{~g} \mathrm{~cm}^{-3}, \mu=0.081 \mathrm{~mm}^{-1}$; $F(000)=616$; crystal size $0.910 \times 0.590 \times 0.090 \mathrm{~mm} ; \theta=3.212$ to 28.272 deg.; $-15 \leq h \leq 13,-20 \leq k \leq 25$, $-7 \leq l \leq 8$; rfln collected $=5790 ;$ rfln unique $=1904$ [ $R($ int $)=0.0572]$; completeness to $\theta=25.242$ deg. $=99.6 \%$; semi empirical absorption correction from equivalents; max. and min. transmission 1.09703 and 0.92830; data 1904; restraints 0, parameters 104; goodness-of-fit on $F^{2}=1.030$; final indices $[I>2 \sigma(I)] R_{1}=0.0504, \mathrm{w} R_{2}=0.1255 ; R$ indices (all data) $R_{1}=0.0907, \mathrm{w} R_{2}=0.1443$; largest diff. peak and hole 0.224 and -0.274 e $\AA^{-3}$.

Crystallographic Data of [H-ddpd] $\left[\mathrm{CF}_{3} \mathrm{SO}_{3}\right]: \mathrm{C}_{18} \mathrm{H}_{18} \mathrm{~F}_{3} \mathrm{~N}_{5} \mathrm{O}_{3} \mathrm{~S}$ (441.43); monoclinic; $P 2_{1} / \mathrm{n}$; $a=8.4486(17) \AA, b=14.467(3) \AA, c=15.549(3) \AA, \beta=97.84(3)^{\circ}, V=1882.7(7) \AA^{3} ; Z=4$; density, calcd. $=1.557 \mathrm{~g} \mathrm{~cm}^{-3}, \mu=0.234 \mathrm{~mm}^{-1} ; F(000)=912 ;$ crystal size $0.540 \times 0.520 \times 0.400 \mathrm{~mm} ; \theta=2.606$ to 28.226 deg.; $-11 \leq h \leq 11,-19 \leq k \leq 16,-20 \leq l \leq 15 ;$ rfln collected $=12534 ;$ rfln unique $=4591$ [ $R$ (int) $=0.0268 \mathrm{]}$; completeness to $\theta=25.242 \mathrm{deg}$. $=99.4 \%$; no absorption correction; data 4591 ; restraints 0 , parameters 277; goodness-of-fit on $F^{2}=1.040$; final indices $[I>2 \sigma(I)] R_{1}=0.0349, \mathrm{w} R_{2}=0.0919$; $R$ indices (all data) $R_{1}=0.0401, \mathrm{w} R_{2}=0.0958$; largest diff. peak and hole 0.437 and $-0.340 \mathrm{e}^{-3}$.

Crystallographic Data of mer-[Co(ddpd $\left.)_{2}\right]\left[\mathrm{BF}_{4}\right]_{3} \times 3 \mathrm{CH}_{3} \mathrm{CN}: \mathrm{C}_{40} \mathrm{H}_{43} \mathrm{~B}_{3} \mathrm{CoF}_{12} \mathrm{~N}_{13} \quad$ (1025.23); monoclinic; $P \mathrm{n} ; a=11.4217(10) \AA, b=16.5963(15) \AA, c=12.9749(11) \AA, \beta=112.100(2)^{\circ}, V=2278.8(3)$ $\AA^{3} ; Z=2$; density, calcd. $=1.494 \mathrm{~g} \mathrm{~cm}^{-3}, \mu=0.473 \mathrm{~mm}^{-1} ; F(000)=1048$; crystal size $0.730 \times 0.430$ $\times 0.220 \mathrm{~mm} ; \theta=2.030$ to $27.987 \mathrm{deg}$; $-15 \leq h \leq 15,-21 \leq k \leq 21,-17 \leq l \leq 17$; rfln collected $=$ 28339; rfln unique $=10797$ [ $R$ (int $)=0.0526]$; completeness to $\theta=25.242$ deg. $=100.0 \%$; semi empirical absorption correction from equivalents; max. and min. transmission 1.179 and 0.888; data 10797; restraints 42, parameters 675; goodness-of-fit on $F^{2}=0.958$; final indices $[I>2 \sigma(I)] R_{1}=0.0473$, $\mathrm{w} R_{2}=0.1047 ; R$ indices (all data) $R_{1}=0.0584, \mathrm{w} R_{2}=0.1094 ;$ largest diff. peak and hole 0.347 and -0.398 e $\AA^{-3}$.

Crystallographic Data of mer-[Fe(ddpd) $\left.)_{2}\right] \mathrm{Br}_{2} \times 2 \mathrm{CH}_{3} \mathrm{CN}: \mathrm{C}_{38} \mathrm{H}_{40} \mathrm{Br}_{2} \mathrm{FeN}_{12}$ (880.49); orthorhombic; Fddd; $a=13.629(3) \AA, b=20.677(4) \AA, c=26.759(5) \AA, V=7541(3) \AA^{3} ; Z=8$; density, calcd. $=1.551 \mathrm{~g}$ $\mathrm{cm}^{-3}, \mu=2.566 \mathrm{~mm}^{-1} ; F(000)=3584 ;$ crystal size $0.200 \times 0.157 \times 0.070 \mathrm{~mm} ; \theta=3.355$ to $28.037 \mathrm{deg}$; $-15 \leq h \leq 17,-27 \leq k \leq 27,-35 \leq l \leq 35 ;$ rfln collected $=12312$; rfln unique $=2273$ [ $R$ (int) $=0.0514]$; completeness to $\theta=25.242 \mathrm{deg} .=99.8 \%$; semi empirical absorption correction from equivalents; max. and min. transmission 1.050 and 0.958; data 2273; restraints 3, parameters 122; goodness-of-fit on $F^{2}=1.059$; final indices $[I>2 \sigma(I)] R_{1}=0.0547, \mathrm{w} R_{2}=0.1641 ; R$ indices (all data) $R_{1}=0.0804$, $\mathrm{w} R_{2}=0.1828$; largest diff. peak and hole 1.726 and -0.823 e $\AA^{-3}$.

Crystallographic Data of mer-[Cr(ddpd $\left.)_{2}\right]\left[\mathrm{BF}_{4}\right]_{2} \times 2 \mathrm{CH}_{3} \mathrm{CN}: \mathrm{C}_{38} \mathrm{H}_{40} \mathrm{~B}_{2} \mathrm{~F}_{8} \mathrm{CrN}_{12}(890.44) ; T=263 \mathrm{~K}$; orthorhombic; Fdd2; $a=21.474(4) \AA, b=26.428(5) \AA, c=14.176(3) \AA, V=8045(3) \AA^{3} ; Z=8$; density, 
calcd. $=1.470 \mathrm{~g} \mathrm{~cm}^{-3}, \mu=0.368 \mathrm{~mm}^{-1} ; F(000)=3664 ;$ crystal size $0.480 \times 0.380 \times 0.300 \mathrm{~mm} ; \theta=2.883$ to 28.236 deg.; $-26 \leq h \leq 28,-30 \leq k \leq 35,-18 \leq l \leq 18$; rfln collected = 10695; rfln unique = 4596 $[R($ int $)=0.0591]$; completeness to $\theta=25.242 \mathrm{deg} .=99.8 \%$; semi empirical absorption correction from equivalents; max. and min. transmission 1.172 and 0.893 ; data 4596; restraints 122, parameters 357; goodness-of-fit on $F^{2}=1.032$; final indices $[I>2 \sigma(I)] R_{1}=0.0455, \mathrm{w} R_{2}=0.1123$; $R$ indices (all data) $R_{1}$ $=0.0708, \mathrm{w} R_{2}=0.1394 ;$ abs. structure parameter $=0.39(7)$, largest diff. peak and hole 0.381 and -0.248 e $\AA^{-3}$.

Crystallographic Data of $\mathrm{VCl}_{3}(\mathrm{ddpd}): \mathrm{C}_{17} \mathrm{H}_{17} \mathrm{Cl}_{3} \mathrm{VN}_{5}$ (448.64); monoclinic; $P 2_{1} / \mathrm{n} ; a=9.2520(19)$ $\AA, b=14.874(3) \AA, c=13.647(3) \AA, \beta=95.99(3)^{\circ}, V=1867.8(7) \AA^{3} ; Z=4$; density, calcd. $=1.595 \mathrm{~g}$ $\mathrm{cm}^{-3}, \mu=0.972 \mathrm{~mm}^{-1} ; F(000)=912$; crystal size $0.600 \times 0.270 \times 0.080 \mathrm{~mm} ; \theta=2.031$ to $28.228 \mathrm{deg}$; $-12 \leq h \leq 12,-17 \leq k \leq 19,-18 \leq l \leq 18$; rfln collected = 12339; rfln unique = $4595[R($ int $)=0.0848]$; completeness to $\theta=25.242 \mathrm{deg}$. $=99.7 \%$; semi empirical absorption correction from equivalents; max. and min. transmission 1.282 and 0.864; data 4595; restraints 0, parameters 237; goodness-of-fit on $F^{2}=1.045$; final indices $[I>2 \sigma(I)] R_{1}=0.0541, \mathrm{w} R_{2}=0.1029 ; R$ indices (all data) $R_{1}=0.1047$,

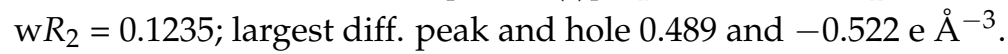

Crystallographic Data of cis-fac-[V(ddpd) $\left.)_{2}\right]\left[\mathrm{PF}_{6}\right]_{3} \times 3 \mathrm{CH}_{3} \mathrm{CN}: \mathrm{C}_{40} \mathrm{H}_{43} \mathrm{P}_{3} \mathrm{VF}_{18} \mathrm{~N}_{13} \quad$ (1191.72); monoclinic; $I 2 / c ; a=22.513(5) \AA, b=12.233(3) \AA, c=37.764(16) \AA, \beta=102.01(3)^{\circ}, V=10173(6) \AA^{3} ; Z=8$; density, calcd. $=1.556 \mathrm{~g} \mathrm{~cm}^{-3}, \mu=0.401 \mathrm{~mm}^{-1} ; F(000)=4832 ;$ crystal size $0.320 \times 0.150 \times 0.040 \mathrm{~mm}$; $\theta=1.904$ to 28.483 deg.; $-30 \leq h \leq 30,-16 \leq k \leq 14,-44 \leq l \leq 50$; rfln collected = 32167; rfln unique $=12717[R(\mathrm{int})=0.2772]$; completeness to $\theta=25.242 \mathrm{deg} .=99.6 \%$; semi empirical absorption correction from equivalents; max. and min. transmission 1.147 and 0.861 ; data 12717 ; restraints 84 , parameters 780; goodness-of-fit on $F^{2}=1.039$; final indices $[I>2 \sigma(I)] R_{1}=0.1357, \mathrm{w} R_{2}=0.2837 ; R$ indices (all data) $R_{1}=0.3163, \mathrm{w} R_{2}=0.3895$; largest diff. peak and hole 1.151 and $-0.540 \mathrm{e} \AA^{-3}$. Unfortunately, only a few needle-shaped crystals were suitable for single-crystal $X$-ray analysis. The investigated needle-shaped crystal was the one of highest quality. Up to now, no crystals with better diffracting power could be obtained and hence no better reflection data. In spite of the weak diffraction quality, the cis-fac coordination mode of the ddpd ligand in this complex salt is unambiguous.

NMR spectra were recorded with a Bruker Avance DRX 400 spectrometer at $400.31 \mathrm{MHz}\left({ }^{1} \mathrm{H}\right)$. All resonances are reported in ppm versus the solvent signal as an internal standard $\left(\mathrm{CD}_{2} \mathrm{Cl}_{2}:{ }^{1} \mathrm{H}_{\text {, }}\right.$ $\delta=5.32$ ppm; $\mathrm{s}=$ singlet, $\mathrm{d}=$ doublet, $\mathrm{t}=$ triplet, $\mathrm{m}=$ multiplet) [161]. IR spectra were recorded with a BioRad Excalibur FTS 3100 spectrometer as KBr disks or with a Bruker Alpha FT-IR spectrometer with an ATR unit containing a diamond crystal. UV/Vis/near-IR spectra were recorded with a Varian Cary 5000 spectrometer by using $1.0 \mathrm{~cm}$ cells (Hellma, Suprasil). ESI ${ }^{+}$mass spectra were recorded with a Micromass Q-TOF-Ultima spectrometer. FD mass spectra were recorded on a Thermo Fisher DFS mass spectrometer with a LIFDI upgrade. DC magnetic studies were performed with a Quantum Design MPMS-XL-7 SQUID magnetometer on powdered microcrystalline samples embedded in eicosane to avoid orientation of the crystallites under applied field (1 Tesla). Experimental susceptibility data were corrected for the underlying diamagnetism using Pascal's constants. The temperature dependent magnetic contribution of the holder and of the embedding matrix eicosane were experimentally determined and subtracted from the measured susceptibility data. Electrochemical experiments were carried out on a BioLogic SP-50 voltammetric analyser using a platinum working electrode, a platinum wire as a counter electrode and a $0.01 \mathrm{M} \mathrm{Ag} / \mathrm{AgNO} \mathrm{CH}_{3} \mathrm{CN}$ electrode as reference electrode. The measurements were carried out at a scan rate of $100 \mathrm{mV} \mathrm{s}^{-1}$ for cyclic voltammetry experiments using $0.1 \mathrm{M}\left[{ }^{n} \mathrm{Bu}_{4} \mathrm{~N}\right]\left[\mathrm{PF}_{6}\right]$ as supporting electrolyte and $0.002 \mathrm{M}$ of the sample in acetonitrile. Potentials are given relative to the ferrocene/ferrocenium couple. Elemental analyses were performed by the microanalytical laboratory of the chemical institutes of the University of Mainz.

DFT calculations were carried out using the ORCA program package (version 4.0.1) [162]. All calculations were performed using the B3LYP functional [163-165] and employ the RIJCOSX approximation $[166,167]$. Relativistic effects were calculated at the zeroth order regular approximation (ZORA) level [168]. The ZORA keyword automatically invokes relativistically adjusted basis sets. 
To account for solvent effects, a conductor-like screening model (CPCM) modelling acetonitrile was used in all calculations [169]. Geometry optimizations were performed using Ahlrichs' split-valence double- $\xi$ basis set def2-SVP, which comprises polarization functions for all non-hydrogen atoms $[170,171]$. Atom-pairwise dispersion correction was performed with the Becke-Johnson damping scheme (D3BJ) [172,173].

Synthesis of $f a c-C r(C O)_{3}(\mathrm{ddpd})$ : Under an inert atmosphere, chromiumhexacarbonyl $(233 \mathrm{mg}$, $1.06 \mathrm{mmol}$ ) and ddpd (684 mg, $2.34 \mathrm{mmol})$ were heated under reflux in mesitylene $(45 \mathrm{~mL})$ for $7 \mathrm{~h}$. After cooling to room temperature, the red precipitate was collected by filtration and washed with diethylether $(3 \times 30 \mathrm{~mL})$. The red solid was dissolved in $\mathrm{CH}_{2} \mathrm{Cl}_{2}$ and the solvent removed under reduced pressure. After washing with petroleum ether, the red solid was dried under reduced pressure. Yield: $410 \mathrm{mg}(0.96 \mathrm{mmol}, 90 \%)$. Elemental Anal. Calc. for $\mathrm{C}_{20} \mathrm{H}_{17} \mathrm{CrN}_{5} \mathrm{O}_{3}(427.37) \times$ $0.2 \mathrm{CH}_{2} \mathrm{Cl}_{2} \mathrm{C}, 54.60 ; \mathrm{H}, 3.95 ; \mathrm{N}, 15.76$. Found: $\mathrm{C}, 53.78 ; \mathrm{H}, 3.95 ; \mathrm{N}, 16.59$. IR (KBr): $\tilde{u}=1891$ (vs, CO), 1775 (vs, CO), 1748 (vs, CO), 1589 (s), 1580 (s), 1488 (s), 1444 (s), 1430 (s), 1373 (m), 1338 (m), $1304(\mathrm{w}), 1276(\mathrm{w}), 1237(\mathrm{w}), 1166(\mathrm{~m}), 1141(\mathrm{~m}), 1131(\mathrm{~m}), 1118(\mathrm{w}), 1100(\mathrm{w}), 1088(\mathrm{w}), 1065(\mathrm{w})$, $1055(\mathrm{w}), 1005(\mathrm{w}), 841$ (w, br), $799(\mathrm{~m}), 773(\mathrm{~s}), 748(\mathrm{~m}), 652(\mathrm{~m}) \mathrm{cm}^{-1}$. MS $\left(\mathrm{ESI}^{+}\right): \mathrm{m} / z(\%)=343.1$ (100) $[\mathrm{M}-3 \mathrm{CO}]^{+}, 371.1(2)\left[\mathrm{M}-2 \mathrm{CO}^{+}, 399.1\right.$ (6) $[\mathrm{M}-\mathrm{CO}]^{+}, 427.1(85)\left[\mathrm{M}^{+} .{ }^{1} \mathrm{H} \mathrm{NMR}\left(\mathrm{CD}_{2} \mathrm{Cl}_{2}\right.\right.$, $400.31 \mathrm{MHz}): \delta[\mathrm{ppm}]=9.13\left(\mathrm{~d},{ }^{3} J_{\mathrm{HH}}=5.6 \mathrm{~Hz}, 2 \mathrm{H}, \mathrm{H7}\right), 7.72\left(\mathrm{t},{ }^{3} J_{\mathrm{HH}}=8.2 \mathrm{~Hz}, 1 \mathrm{H}, \mathrm{H}^{1}\right), 7.71(\mathrm{~m}, 2 \mathrm{H}$, $\left.\mathrm{H}^{5}\right), 7.10\left(\mathrm{ddd},{ }^{3} J_{\mathrm{HH}}=7.0 \mathrm{~Hz},{ }^{3} J_{\mathrm{HH}}=5.9 \mathrm{~Hz},{ }^{4} J_{\mathrm{HH}}=0.9 \mathrm{~Hz}, 2 \mathrm{H}, \mathrm{H}^{6}\right), 7.02\left(\mathrm{~d},{ }^{3} J_{\mathrm{HH}}=8.2 \mathrm{~Hz}, 2 \mathrm{H}, \mathrm{H}^{4}\right)$, $6.66\left(\mathrm{~d},{ }^{3} J_{\mathrm{HH}}=8.2 \mathrm{~Hz}, 2 \mathrm{H}, \mathrm{H}^{2}\right), 3.62\left(\mathrm{~s}, 6 \mathrm{H}, \mathrm{H}^{3}\right)$. UV/Vis/NIR $\left(\mathrm{CH}_{2} \mathrm{Cl}_{2}\right): \lambda\left(\varepsilon / \mathrm{M}^{-1} \mathrm{~cm}^{-1}\right)=445(7220)$, 328 (sh, 14100), 298 (17500), 259 (sh, 24700) nm.

Synthesis of crystals of mer-[Cr(ddpd $\left.)_{2}\right]\left[\mathrm{BF}_{4}\right]_{2} \times \mathbf{2 C H}_{3} \mathrm{CN}$ : Under an inert atmosphere, [Cr $\left.\left(\mathrm{NCCH}_{3}\right)_{4}\right]\left[\mathrm{BF}_{4}\right]_{2}[128](13.5 \mathrm{mg}, 0.035 \mathrm{mmol})$ was dissolved in acetonitrile $(5 \mathrm{~mL})$ giving a pale blue solution. Upon dropwise addition of ddpd $(20 \mathrm{mg}, 0.069 \mathrm{mmol})$ dissolved in acetonitrile $(1 \mathrm{~mL})$ the solution turned green. Diffusion of diethyl ether into the solution yielded dark green crystals suitable for single crystals $\mathrm{X}$-ray diffraction and magnetic susceptibility studies. Magnetic susceptibility (Evans NMR method [174,175]): $\chi \mathrm{T}\left(\mathrm{CH}_{3} \mathrm{CN}\right)=2.67 \mathrm{~cm}^{3} \mathrm{~K} \mathrm{~mol}^{-1}(294 \mathrm{~K})$.

Synthesis of $m e r-\mathrm{VCl}_{3}$ (ddpd): Under an inert atmosphere, $\mathrm{VCl}_{3}(\text { thf })_{3}$ [150] $(50 \mathrm{mg}, 0.13 \mathrm{mmol})$ was dissolved in acetonitrile $(2 \mathrm{~mL})$ giving a green solution. Upon addition of ddpd $(47 \mathrm{mg}, 0.16 \mathrm{mmol})$, dissolved in dry acetonitrile $(2 \mathrm{~mL})$, the solution turned red and an orange solid started to precipitate. The reaction mixture was heated to reflux for $2 \mathrm{~h}$ to give a yellow solution over an orange solid. The solvent was removed under reduced pressure and the orange product was washed under argon with dry petrol ether $(40 / 60)(3 \times 5 \mathrm{~mL})$ onto a frit to remove excess ligand. After drying under reduced pressure overnight, a fine-grained orange solid was obtained. Yield: $55 \mathrm{mg}(0.12 \mathrm{mmol}, 92 \%)$. MS (LIFDI): $m / z(\%)=291.2(58)[\mathrm{ddpd}]^{+}, 393.2(100), 412.2(34)[\mathrm{M}-\mathrm{Cl}]^{+}$. UV/Vis/NIR $\left(\mathrm{CH}_{2} \mathrm{Cl}_{2}\right):$ $\lambda\left(\varepsilon / \mathrm{M}^{-1} \mathrm{~cm}^{-1}\right)=455$ (980), 385 (sh, 2240), 322 (14470), 245 (17080) nm. IR (ATR): $\tilde{u}=2960(\mathrm{w})$, $1589(\mathrm{~m}), 1566(\mathrm{w}), 1488(\mathrm{vw}), 1472(\mathrm{w}), 1432(\mathrm{~s}), 1411(\mathrm{~m}), 1389(\mathrm{w}), 1354(\mathrm{w}), 1284(\mathrm{vw}), 1259(\mathrm{~m})$, $1195(\mathrm{w}), 1171(\mathrm{w}), 1160(\mathrm{w}), 1129(\mathrm{~m}), 1094(\mathrm{~s}, \mathrm{br}), 1082(\mathrm{~s}, \mathrm{br}), 1014$ (s), $964(\mathrm{~m}), 888(\mathrm{sh}), 874(\mathrm{w}, \mathrm{br})$, 795 (s, br), $773(\mathrm{vs}), 752(\mathrm{~m}), 746(\mathrm{~m}), 727(\mathrm{~m}), 707(\mathrm{w}), 663(\mathrm{w}), 630(\mathrm{vw}), 593(\mathrm{~m}), 562(\mathrm{w})$. Elem. Anal. Calcd. for $\mathrm{C}_{17} \mathrm{H}_{17} \mathrm{Cl}_{3} \mathrm{~N}_{5} \mathrm{~V}(488.66) \times 0.9 \mathrm{CH}_{3} \mathrm{CN}$ : C, 46.50, H, 4.09, N, 17.02. Found: C, 45.93, H, 3.75, N, 17.59. $\chi \mathrm{T}=0.879 \mathrm{~cm}^{-1} \mathrm{~K} \mathrm{~mol}^{-1}(290 \mathrm{~K})$.

\section{Conclusions and Future Perspectives}

Transition metal complexes of ddpd $\left[\mathrm{M}(\mathrm{ddpd})_{2}\right]^{n+}$ with $\mathrm{d}^{2}$ (vanadium(III)) to $\mathrm{d}^{10}$ (zinc(II)) electron configurations are readily available. In all cases, the complex charge corresponds to the metal oxidation state. This is not generally valid for corresponding $\left[\mathrm{M}(\mathrm{tpy})_{2}\right]^{n+}$ complexes due to the redox non-innocence of terpyridine allowing $\left[\mathrm{M}^{n}\left(\text { tpy } \cdot^{-}\right)(\text {tpy })\right]^{(n-1)+}$ electronic structures, for example, $\left[\mathrm{Cr}^{\mathrm{III}}\left(\mathrm{tpy}^{-}{ }^{-}\right)(\text {tpy })\right]^{2+}$ versus $\left[\mathrm{Cr}^{\mathrm{II}}(\mathrm{ddpd})_{2}\right]^{2+}$. The electron-rich nature of ddpd stabilizes electron-deficient complexes, whereas the $\pi$ electron accepting tpy favours electron-rich metal ions.

The six-membered chelate rings of ddpd form larger ligand bite angles and geometries closer to an ideal octahedron than the more strained tpy ligand. The increased flexibility of the six-membered 
rings allow both pincer type (meridional) and tripodal (facial) coordination of ddpd, for example merand cis-fac- $\left[\mathrm{Co}(\mathrm{ddpd})_{2}\right]^{2+}$ complexes. The meridional isomers $\left[\mathrm{M}(\mathrm{ddpd})_{2}\right]^{n+}$ are typically preferred and most often encountered. The bite angles of ddpd close to $90^{\circ}$ enable a better metal orbital-pyridine orbital overlap. This results in generally larger ligand field splittings than in the corresponding $\left[\mathrm{M}(\mathrm{tpy})_{2}\right]^{n+}$ complexes (except for high-spin $\left[\mathrm{Co}(\mathrm{L})_{2}\right]^{2+}$ complexes). The ligand field splitting affects both the ground state multiplicity (low-spin/high-spin) and the excited state level ordering, especially in $\mathrm{d}^{3}$ complexes. Specifically, the very strong ligand field strength of ddpd enables strongly luminescent chromium(III) complexes due to the high energy of the detrimental ligand field states. Electron configurations with degenerate electronic states, especially $\left(\mathrm{e}_{\mathrm{g}}\right)^{1}$ and $\left(\mathrm{e}_{\mathrm{g}}\right)^{3}$ configurations, for example high-spin $d^{4}-\left[\mathrm{Cr}(\mathrm{ddpd})_{2}\right]^{2+}$, low-spin $\mathrm{d}^{7}-\left[\mathrm{Co}(\text { tpy })_{2}\right]^{2+}$ and $\mathrm{d}^{9}-\left[\mathrm{Cu}(\mathrm{L})_{2}\right]^{2+}$ are prone to significant Jahn-Teller distortions. The barrier between the Jahn-Teller isomers of $\left[\mathrm{Cu}(\mathrm{ddpd})_{2}\right]^{2+}$ is larger than that of $\left[\mathrm{Cu}(\mathrm{tpy})_{2}\right]^{2+}$. Spin-crossover phenomena have been reported for $\left[\mathrm{Co}(\mathrm{tpy})_{2}\right][\mathrm{X}]_{2}$ and $\left[\mathrm{Fe}\left(\mathrm{R}_{2} \mathrm{tpy}\right)_{2}\right][\mathrm{X}]_{2}$ salts with substituents $R$ at the $6,6^{\prime \prime}$ positions of tpy. Analogous $\left[\mathrm{Co}(\mathrm{ddpd})_{2}\right][\mathrm{X}]_{2}$ salts have not yet been discovered with low-spin spin states but might be available with different counter ions or within different matrices. Iron(II) complexes with unsubstituted ddpd ligands are all low-spin. However, lowering the ligand field strength by $6,6^{\prime \prime}$ substitution might be a promising strategy, similar to the tpy complexes.

Modification of ddpd to tune the ligand field strength (higher or lower), to allow for conjugation with functional groups such as light antenna or catalysts, for incorporation into supramolecular arrays or for immobilization on surfaces or in nanoparticles are important future perspectives of transition metal ddpd complexes. The deliberate incorporation of ddpd in heteroleptic chelate complexes will further open plentiful tuning possibilities with respect to optical, magnetic and catalytic properties. These future developments will possibly enable applications of $\left[\mathrm{M}(\mathrm{ddpd})(\mathrm{L})_{\mathrm{m}}\right]^{n+}$ in magnetic storage devices, optical sensing, catalysis, electrocatalysis, photocatalysis and supramolecular chemistry.

Supplementary Materials: The following are available online at http://www.mdpi.com/2304-6740/6/3/86/ s1. Figure S1: Cyclic voltammogram of $\left[\mathrm{Ni}(\mathrm{ddpd})_{2}\right]\left[\mathrm{BF}_{4}\right]_{2}$ in $\mathrm{CH}_{3} \mathrm{CN}$ in the presence of $\mathrm{HOAC}$ and $\mathrm{CO}_{2}$, Figure S2: Temperature-dependence of $\chi_{\mathrm{M}} \mathrm{T}$ of $\left[\mathrm{Cr}(\mathrm{ddpd})_{2}\right]\left[\mathrm{BF}_{4}\right]_{3} \times \mathrm{CH}_{3} \mathrm{CN}$ with fit, Figure S3: UV/Vis spectrum of mer- $\mathrm{VCl}_{3}$ (ddpd) in $\mathrm{CH}_{2} \mathrm{Cl}_{2}$, Figure S4: Temperature-dependence of $\chi_{\mathrm{M}} \mathrm{T}$ of $\mathrm{VCl}_{3}$ (ddpd) with fit. The CIF and the checkCIF output files of ddpd, [H-ddpd] $\left[\mathrm{CF}_{3} \mathrm{SO}_{3}\right]$, mer-[Co(ddpd) $\left.)_{2}\right]\left[\mathrm{BF}_{4}\right]_{3} \times 3 \mathrm{CH}_{3} \mathrm{CN}$, mer-[Fe(ddpd) $\left.{ }_{2}\right] \mathrm{Br}_{2} \times 2 \mathrm{CH}_{3} \mathrm{CN}_{\text {, }}$ mer-Cr(ddpd $\left.)_{2}\right]\left[\mathrm{BF}_{4}\right]_{2} \times 2 \mathrm{CH}_{3} \mathrm{CN}, \mathrm{VCl}_{3}(\mathrm{ddpd})$ and cis-fac-[V(ddpd) $\left.)_{2}\right]\left[\mathrm{PF}_{6}\right]_{3} \times 3 \mathrm{CH}_{3} \mathrm{CN}$.

Author Contributions: C.F. solved and refined the X-ray data, M.D. (cis-fac-[V(ddpd $\left.)_{2}\right]\left[\mathrm{PF}_{6}\right]_{3} \times 3 \mathrm{CH}_{3} \mathrm{CN}_{\text {, }}$ $\left.\mathrm{VCl}_{3}(\mathrm{ddpd})\right)$, T.R. (ddpd), S.O. $\left(f a c-\mathrm{Cr}(\mathrm{CO})_{3}(\mathrm{ddpd})\right.$, mer- $\left[\mathrm{Cr}(\mathrm{ddpd})_{2}\right]\left[\mathrm{BF}_{4}\right]_{2} \times 2 \mathrm{CH}_{3} \mathrm{CN}$, mer- $\left[\mathrm{Co}(\mathrm{ddpd})_{2}\right]\left[\mathrm{BF}_{4}\right]_{3} \times$ $\left.3 \mathrm{CH}_{3} \mathrm{CN}\right)$, G.D. and T.R. ([H-ddpd] $\left.\left[\mathrm{CF}_{3} \mathrm{SO}_{3}\right]\right)$ prepared or crystallized the new compounds, respectively. L.C. and E.R. measured and analysed the magnetic data, K.H. designed the project and wrote the manuscript. All authors have given approval to the final version of the manuscript.

Acknowledgments: We gratefully thank all collaboration partners who have contributed to this interdisciplinary research area. Their names can be found in the respective references. We thank Katharina Mack for crystallizing the complex mer-[Fe(ddpd $\left.)_{2}\right] \mathrm{Br}_{2} \times 2 \mathrm{CH}_{3} \mathrm{CN}$. We thank Regine Jung-Pothmann and Dieter Schollmeyer for the collection of the diffraction data. Parts of this research were conducted using the supercomputer Mogon and advisory services offered by the Johannes Gutenberg University Mainz (www.hpc.uni-mainz.de), which is a member of the AHRP and the Gauss Alliance e.V. This work was supported by the Deutsche Forschungsgemeinschaft (GSC 266, Materials Science in Mainz and HE 2778/10-1), the internal university research funds of the Johannes Gutenberg University, Mainz (Germany) and the Center for INnovative and Emerging MAterials (CINEMA).

Conflicts of Interest: The authors declare no conflict of interest.

\section{References}

1. Lawrence, M.A.W.; Green, K.-A.; Nelson, P.N.; Lorraine, S.C. Review: Pincer ligands-Tunable, versatile and applicable. Polyhedron 2018, 143, 11-27. [CrossRef]

2. Peris, E.; Crabtree, R.H. Key factors in pincer ligand design. Chem. Soc. Rev. 2018, 47, 1959-1968. [CrossRef]

3. Constable, E.C. The Coordination Chemistry of $2,2^{\prime}: 6^{\prime}, 2^{\prime \prime}$-Terpyridine and Higher Oligopyridines. Adv. Inorg. Chem. 1986, 30, 69-121. [CrossRef] 
4. Constable, E.C. $2,2^{\prime}: 6^{\prime}, 2^{\prime \prime}$-terpyridines: From chemical obscurity to common supramolecular motifs. Chem. Soc. Rev. 2007, 36, 246-253. [CrossRef]

5. Hofmeier, H.; Schubert, U.S. Recent developments in the supramolecular chemistry of terpyridine-metal complexes. Chem. Soc. Rev. 2004, 33, 373-399. [CrossRef] [PubMed]

6. Sauvage, J.P.; Collin, J.P.; Chambron, J.C.; Guillerez, S.; Coudret, C.; Balzani, V.; Barigelletti, F.; De Cola, L.; Flamigni, L. Ruthenium(II) and Osmium(II) Bis(terpyridine) Complexes in Covalently-Linked Multicomponent Systems: Synthesis, Electrochemical Behavior, Absorption Spectra, and Photochemical and Photophysical Properties. Chem. Rev. 1994, 94, 993-1019. [CrossRef]

7. Flamigni, L.; Collin, J.P.; Sauvage, J.P. Iridium Terpyridine Complexes as Functional Assembling Units in Arrays for the Conversion of Light Energy. Acc. Chem. Res. 2008, 41, 857-871. [CrossRef] [PubMed]

8. Cook, T.R.; Stang, P.J. Recent Developments in the Preparation and Chemistry of Metallacycles and Metallacages via Coordination. Chem. Rev. 2015, 115, 7001-7045. [CrossRef] [PubMed]

9. Yin, G.-Q.; Wang, H.; Wang, X.-Q.; Song, B.; Chen, L.-J.; Wang, L.; Hao, X.-Q.; Yang, H.-B.; Li, X. Self-assembly of emissive supramolecular rosettes with increasing complexity using multitopic terpyridine ligands. Nat. Commun. 2018, 9, 567. [CrossRef] [PubMed]

10. Hasenknopf, B.; Lehn, J.-M.; Baum, G.; Fenske, D. Self-assembly of a heteroduplex helicate from two different ligand strands and Cu(II) cations. Proc. Natl. Acad. Sci. USA 1996, 93, 1397-1400. [CrossRef] [PubMed]

11. Bassani, D.M.; Lehn, J.-M.; Fromm, K.; Fenske, D. Toposelective and Chiroselective Self-Assembly of [2 $\times 2]$ Grid-Type Inorganic Arrays Containing Different Octahedral Metallic Centers. Angew. Chem. Int. Ed. 1998, 37, 2364-2367. [CrossRef]

12. Cárdenas, D.J.; Livoreil, A.; Sauvage, J.-P. Redox Control of the Ring-Gliding Motion in a Cu-Complexed Catenane: A Process Involving Three Distinct Geometries. J. Am. Chem. Soc. 1996, 118, 11980-11981. [CrossRef]

13. Baumann, F.; Livoreil, A.; Kaim, W.; Sauvage, J.-P. Changeover in a multimodal copper(II) catenate as monitored by EPR spectroscopy. Chem. Commun. 1997, 35-36. [CrossRef]

14. Livoreil, A.; Sauvage, J.-P.; Armaroli, N.; Balzani, V.; Flamigni, L.; Ventura, B. Electrochemically and Photochemically Driven Ring Motions in a Disymmetrical Copper [2]-Catenate. J. Am. Chem. Soc. 1997, 119, 12114-12124. [CrossRef] [PubMed]

15. Hayami, S.; Komatsu, Y.; Shimizu, T.; Kamihata, H.; Lee, Y.H. Spin-crossover in cobalt(II) compounds containing terpyridine and its derivatives. Coord. Chem. Rev. 2011, 255, 1981-1990. [CrossRef]

16. Krivokapic, I.; Zerara, M.; Dakua, M.L.; Vargas, A.; Enachescu, C.; Ambrus, C.; Tregenna-Piggott, P.; Amstutz, N.; Krausz, E.; Hauser, A. Spin-crossover in cobalt(II) imine complexes. Coord. Chem. Rev. 2007, 251, 364-378. [CrossRef]

17. Gütlich, P.; Garcia, Y.; Goodwin, H.A. Spin crossover phenomena in Fe(II) complexes. Chem. Soc. Rev. 2000, 29, 419-427. [CrossRef]

18. Constable, E.C.; Baum, G.; Bill, E.; Dyson, R.; van Eldik, R.; Fenske, D.; Kaderli, S.; Morris, D.; Neubrand, A.; Neuburger, M.; et al. Control of Iron(II) Spin States in $2,2^{\prime}: 6^{\prime}, 2^{\prime \prime}$-Terpyridine Complexes through Ligand Substitution. Chem. Eur. 1999, 5, 498-508. [CrossRef]

19. Budnikova, Y.H.; Vicic, D.A.; Klein, A. Exploring Mechanisms in Ni Terpyridine Catalyzed C-C Cross-Coupling Reactions-A Review. Inorganics 2018, 6, 18. [CrossRef]

20. Elgrishi, N.; Chambers, M.B.; Artero, V.; Fontecave, M. Terpyridine complexes of first row transition metals and electrochemical reduction of $\mathrm{CO}_{2}$ to CO. Phys. Chem. Chem. Phys. 2014, 16, 13635-13644. [CrossRef] [PubMed]

21. Winter, A.; Newkome, G.R.; Schubert, U.S. Catalytic Applications of Terpyridines and their Transition Metal Complexes. ChemCatChem 2011, 3, 1384-1406. [CrossRef]

22. Winter, A.; Gottschaldt, M.; Newkome, G.R.; Schubert, U.S. Terpyridines and their complexes with first row transition metal ions: Cytotoxicity, nuclease activity and self-assembly of biomacromolecules. Curr. Top. Med. Chem. 2012, 12, 158-175. [CrossRef] [PubMed]

23. Wang, M.; England, J.; Weyhermüller, T.; Wieghardt, K. Electronic Structures of "Low-Valent" Neutral Complexes $\left[\mathrm{NiL}_{2}\right]^{0}(S=0 ; \mathrm{L}=$ bpy, phen, tpy)—An Experimental and DFT Computational Study. Eur. J. Inorg. Chem. 2015, 1511-1523. [CrossRef] 
24. England, J.; Bill, E.; Weyhermüller, T.; Neese, F.; Atanasov, M.; Wieghardt, K. Molecular and Electronic Structures of Homoleptic Six-Coordinate Cobalt(I) Complexes of 2,2':6' ,2" -Terpyridine, 2,2'-Bipyridine, and 1,10-Phenanthroline. An Experimental and Computational Study. Inorg. Chem. 2015, 54, 12002-12018. [CrossRef] [PubMed]

25. England, J.; Scarborough, C.C.; Weyhermüller, T.; Sproules, S.; Wieghardt, K. Electronic Structures of the Electron Transfer Series $\left[\mathrm{M}(\mathrm{bpy})_{3}\right]^{n},\left[\mathrm{M}(\mathrm{tpy})_{2}\right]^{n}$, and $\left[\mathrm{Fe}\left({ }^{\mathrm{t} b p y}\right)_{3}\right]^{n}(\mathrm{M}=\mathrm{Fe}, \mathrm{Ru} ; n=3+, 2+, 1+, 0,1-)$ : A Mössbauer Spectroscopic and DFT Study. Eur. J. Inorg. Chem. 2012, 4605-4621. [CrossRef]

26. Wang, M.; England, J.; Weyhermüller, T.; Wieghardt, K. Molecular and Electronic Structures of the Members of the Electron Transfer Series $\left[\mathrm{Mn}(\mathrm{bpy})_{3}\right]^{n}(n=2+, 1+, 0,1-)$ and $\left[\mathrm{Mn}(\mathrm{tpy})_{2}\right]^{m}(m=4+, 3+, 2+, 1+, 0)$. An Experimental and Density Functional Theory Study. Inorg. Chem. 2014, 53, 2276-2287. [CrossRef] [PubMed]

27. Scarborough, C.C.; Lancaster, K.M.; DeBeer, S.; Weyhermüller, T.; Sproules, S.; Wieghardt, K. Experimental Fingerprints for Redox-Active Terpyridine in $\left[\mathrm{Cr}(\mathrm{tpy})_{2}\right]\left(\mathrm{PF}_{6}\right)_{n}(n=3-0)$, and the Remarkable Electronic Structure of $\left[\mathrm{Cr}(\mathrm{tpy})_{2}\right]^{1-}$. Inorg. Chem. 2012, 51, 3718-3732. [CrossRef] [PubMed]

28. Breivogel, A.; Kreitner, C.; Heinze, K. Redox and Photochemistry of Bis(terpyridine)ruthenium(II) Amino Acids and Their Amide Conjugates-from Understanding to Applications. Eur. J. Inorg. Chem. 2014, 5468-5490. [CrossRef]

29. Parada, G.A.; Fredin, L.A.; Santoni, M.-P.; Jäger, M.; Lomoth, R.; Hammarström, L.; Johansson, O.; Persson, P.; Ott, S. Tuning the Electronics of Bis(tridentate)ruthenium(II) Complexes with Long-Lived Excited States: Modifications to the Ligand Skeleton beyond Classical Electron Donor or Electron Withdrawing Group Decorations. Inorg. Chem. 2013, 52, 5128-5137. [CrossRef] [PubMed]

30. Laramée-Milette, B.; Hanan, G.S. Ruthenium bistridentate complexes with non-symmetrical hexahydro-pyrimidopyrimidine ligands: A structural and theoretical investigation of their optical and electrochemical properties. Dalton Trans. 2016, 45, 12507-12517. [CrossRef] [PubMed]

31. Breivogel, A.; Wooh, S.; Dietrich, J.; Kim, T.Y.; Kang, Y.S.; Char, K.; Heinze, K. Anchor-Functionalized Push-Pull-Substituted Bis(tridentate) Ruthenium(II) Polypyridine Chromophores: Photostability and Evaluation as Photosensitizers. Eur. J. Inorg. Chem. 2014, 2720-2734. [CrossRef]

32. Breivogel, A.; Park, M.; Lee, D.; Klassen, S.; Kühnle, A.; Lee, C.; Char, K.; Heinze, K. Push-Pull Design of Bis(tridentate) Ruthenium(II) Polypyridine Chromophores as Deep Red Light Emitters in Light-Emitting Electrochemical Cells. Eur. J. Inorg. Chem. 2014, 288-295. [CrossRef]

33. Breivogel, A.; Meister, M.; Förster, C.; Laquai, F.; Heinze, K. Excited State Tuning of Bis(tridentate) Ruthenium(II) Polypyridine Chromophores by Push-Pull Effects and Bite Angle Optimization: A Comprehensive Experimental and Theoretical Study. Chem. Eur. J. 2013, 19, 13745-13760. [CrossRef] [PubMed]

34. Friebe, C.; Görls, H.; Jäger, M.; Schubert, U.S. Linear Metallopolymers from Ruthenium(II)-2,6-di(quinolin-8yl)pyridine Complexes by Electropolymerization-Formation of Redox-Stable and Emissive Films. Eur. J. Inorg. Chem. 2013, 4191-4202. [CrossRef]

35. Breivogel, A.; Förster, C.; Heinze, K. A Heteroleptic Bis(tridentate)ruthenium(II) Polypyridine Complex with Improved Photophysical Properties and Integrated Functionalizability. Inorg. Chem. 2010, 49, 7052-7056. [CrossRef] [PubMed]

36. Schramm, F.; Meded, V.; Fliegl, H.; Fink, K.; Fuhr, O.; Qu, Z.; Klopper, W.; Finn, S.; Keyes, T.E.; Ruben, M. Expanding the Coordination Cage: A Ruthenium(II)-Polypyridine Complex Exhibiting High Quantum Yields under Ambient Conditions. Inorg. Chem. 2009, 48, 5677-5684. [CrossRef] [PubMed]

37. Abrahamsson, M.; Jäger, M.; Österman, T.; Eriksson, L.; Persson, P.; Becker, H.-C.; Johansson, O.; Hammarström, L. A 3.0 s Room Temperature Excited State Lifetime of a Bistridentate Ru ${ }^{\mathrm{II}}$-Polypyridine Complex for Rod-like Molecular Arrays. J. Am. Chem. Soc. 2006, 128, 12616-12617. [CrossRef] [PubMed]

38. Abrahamsson, M.; Wolpher, H.; Johansson, O.; Larsson, J.; Kritikos, M.; Eriksson, L.; Norrby, P.-O.; Bergquist, J.; Sun, L.; Åkermark, B.; et al. A New Strategy for the Improvement of Photophysical Properties in Ruthenium(II) Polypyridyl Complexes. Synthesis and Photophysical and Electrochemical Characterization of Six Mononuclear Ruthenium(II) Bisterpyridine-Type Complexes. Inorg. Chem. 2005, 44, 3215-3225. [CrossRef] [PubMed]

39. Kröhnke, F. The Specific Synthesis of Pyridines and Oligopyridines. Synthesis 1976, 1-24. [CrossRef] 
40. Heller, M.; Schubert, U.S. Syntheses of Functionalized 2,2':,2"'-Terpyridines. Eur. J. Org. Chem. 2003, 947-961. [CrossRef]

41. Ho, K.-Y.; Yu, W.-Y.; Cheung, K.-K.; Che, C.-M. Blue luminescent zinc(II) complexes with polypyridylamine ligands: Crystal structures and luminescence properties. J. Chem. Soc. Dalton Trans. 1999, 1581-1586. [CrossRef]

42. Wang, C.; Otto, S.; Dorn, M.; Kreidt, E.; Lebon, J.; Sršan, L.; Di Martino-Fumo, P.; Gerhards, M.; Resch-Genger, U.; Seitz, M.; et al. Deuterated Molecular Ruby with Record Luminescence Quantum Yield. Angew. Chem. Int. Ed. 2018, 57, 1112-1116. [CrossRef] [PubMed]

43. Mengel, A.K.C.; Bissinger, C.; Dorn, M.; Back, O.; Förster, C.; Heinze, K. Boosting Vis /NIR Charge-Transfer Absorptions of Iron(II) Complexes by N-Alkylation and N-Deprotonation in the Ligand Backbone. Chem. Eur. J. 2017, 23, 7920-7931. [CrossRef] [PubMed]

44. Bessel, C.A.; See, R.F.; Jameson, D.L.; Churchill, M.R.; Takeuchi, K.J. Structural considerations of terdentate ligands: Crystal structures of 2,2' $: 6^{\prime}, 2^{\prime \prime}$-terpyridine and 2,6-bis(pyrazol-1-yl)pyridine. J. Chem. Soc. Dalton Trans. 1992, 3223-3228. [CrossRef]

45. Pearson, R.G.; Williams, F.V. Rates of Ionization of Pseudo Acids. ${ }^{1}$ V. Steric Effects in the Base-catalyzed Ionization of Nitroethane. J. Am. Chem. Soc. 1953, 75, 3073-3075. [CrossRef]

46. Kaljurand, I.; Kütt, A.; Sooväli, L.; Rodima, T.; Mäemets, V.; Leito, I.; Koppel, I.A. Extension of the Self-Consistent Spectrophotometric Basicity Scale in Acetonitrile to a Full Span of $28 \mathrm{p} K_{\mathrm{a}}$ Units: Unification of Different Basicity Scales. J. Org. Chem. 2005, 70, 1019-1028. [CrossRef] [PubMed]

47. Staab, H.A.; Saupe, T. "Proton Sponges" and the Geometry of Hydrogen Bonds: Aromatic Nitrogen Bases with Exceptional Basicities. Angew. Chem. Int. Ed. Engl. 1988, 27, 865-879. [CrossRef]

48. Hergold-Brundić, A.; Popović, Z.; Matković-Calogović, D. 2,2' $: 6^{\prime}, 2^{\prime \prime}$-Terpyridinium Trifluoromethanesulfonate, [terpyH] $\left(\mathrm{CF}_{3} \mathrm{SO}_{3}\right)$. Acta Cryst. 1996, C52, 3154-3157. [CrossRef]

49. Otto, S.; Moll, J.; Förster, C.; Geißler, D.; Wang, C.; Resch-Genger, U.; Heinze, K. Three-in-One Crystal: The Coordination Diversity of Zinc Polypyridine Complexes. Eur. J. Inorg. Chem. 2017, 5033-5040. [CrossRef]

50. Otto, S.; Grabolle, M.; Förster, C.; Kreitner, C.; Resch-Genger, U.; Heinze, K. [Cr(ddpd) $]^{3+}$ : A Molecular, Water-Soluble, Highly NIR-Emissive Ruby Analogue. Angew. Chem. Int. Ed. 2015, 54, 11572-11576. [CrossRef] [PubMed]

51. Yoshikawa, N.; Yamabe, S.; Kanehisa, N.; Takashima, H.; Tsukahara, K. A metal free blue emission by the protonated 2,2':6',2" -terpyridine hexafluorophosphate. J. Phys. Org. Chem. 2009, 22, 410-417. [CrossRef]

52. Hamacher, C.; Hurkes, N.; Kaiser, A.; Klein, A.; Schüren, A. Electrochemistry and Spectroscopy of Organometallic Terpyridine Nickel Complexes. Inorg. Chem. 2009, 48, 9947-9951. [CrossRef] [PubMed]

53. Otto, S.; Dorn, M.; Förster, C.; Bauer, M.; Seitz, M.; Heinze, K. Understanding and exploiting long-lived near-infrared emission of a molecular ruby. Coord. Chem. Rev. 2018, 359, 102-111. [CrossRef]

54. Alemany, P.; Casanova, D.; Alvarez, S.; Dryzun, C.; Avnir, D. Continuous Symmetry Measures: A New Tool in Quantum Chemistry. In Reviews in Computational Chemistry; Parrill, A.L., Lipkowitz, K.B., Eds.; John Wiley \& Sons: Hoboken, NJ, USA, 2017; Volume 30, pp. 289-352.

55. Alvarez, S. Distortion Pathways of Transition Metal Coordination Polyhedra Induced by Chelating Topology. Chem. Rev. 2015, 115, 13447-13483. [CrossRef] [PubMed]

56. Alvarez, S.; Alemany, P.; Casanova, D.; Cirera, J.; Llunell, M.; Avnir, D. Shape maps and polyhedral interconversion paths in transition metal chemistry. Coord. Chem. Rev. 2005, 249, 1693-1708. [CrossRef]

57. Alvarez, S.; Avnir, D.; Llunell, M.; Pinsky, M. Continuous symmetry maps and shape classification. The case of six-coordinated metal compounds. New J. Chem. 2002, 26, 996-1009. [CrossRef]

58. Zabrodsky, H.; Peleg, S.; Avnir, D. Continuous Symmetry Measures. J. Am. Chem. Soc. 1992, 114, 7843-7851. [CrossRef]

59. Jahn, H.A.; Teller, E. Stability of polyatomic molecules in degenerate electronic states-I-Orbital degeneracy. Proc. R. Soc. Lond. A 1937, 161, 220-235. [CrossRef]

60. Mack, K.; Wünsche von Leupoldt, A.; Förster, C.; Ezhevskaya, M.; Hinderberger, D.; Klinkhammer, K.W.; Heinze, K. Effect of chelate ring expansion on Jahn-Teller distortion and Jahn-Teller dynamics in copper(II) complexes. Inorg. Chem. 2012, 51, 7851-7858. [CrossRef] [PubMed]

61. Dorn, M.; Mack, K.; Carrella, L.M.; Rentschler, E.; Förster, C.; Heinze, K. Structure and electronic properties of an expanded terpyridine complex of nickel(II) $\left[\mathrm{Ni}(\mathrm{ddpd})_{2}\right]\left(\mathrm{BF}_{4}\right)_{2}$. Z. Anorg. Allg. Chem. 2018, 644, 706-712. [CrossRef] 
62. Förster, C.; Mack, K.; Carrella, L.M.; Ksenofontov, V.; Rentschler, E.; Heinze, K. Coordination of expanded terpyridine ligands to cobalt. Polyhedron 2013, 52, 576-581. [CrossRef]

63. Förster, C.; Gorelik, T.E.; Kolb, U.; Ksenofontov, V.; Heinze, K. Crystalline Non-Equilibrium Phase of a Cobalt(II) Complex with Tridentate Ligands. Eur. J. Inorg. Chem. 2015, 920-924. [CrossRef]

64. Mengel, A.K.C.; Förster, C.; Breivogel, A.; Mack, K.; Ochsmann, J.R.; Laquai, F.; Ksenofontov, V.; Heinze, K. A Heteroleptic Push-Pull Substituted Iron(II) Bis(tridentate) Complex with Low-Energy Charge-Transfer States. Chem. Eur. J. 2015, 21, 704-714. [CrossRef] [PubMed]

65. Skelton, B.W.; Harrowfield, J.M. CCDC 1585922, Experimental Crystal Structure Determination (2017), doi:10.5517/ccdc.csd.cc1q78s0. Available online: https:/ / www.ccdc.cam.ac.uk/structures/search?id=doi: 10.5517/ccdc.csd.cc1q78s0\&sid=DataCite (accessed on 26 July 2018).

66. Docherty, R.; Tuna, F.; Kilner, C.A.; McInnes, E.J.L.; Halcrow, M.A. Suppression of the Jahn-Teller distortion in a six-coordinate copper(II) complex by doping it into a host lattice. Chem. Commun. 2012, 48, 4055-4057. [CrossRef] [PubMed]

67. Anderer, C.; Näther, C.; Bensch, W. Bis $\left(2,2^{\prime}: 6^{\prime}, 2^{\prime \prime}\right.$-terpyridine- $\left.\kappa^{3} \mathrm{~N}, \mathrm{~N}^{\prime}, \mathrm{N}^{\prime \prime}\right)$ nickel(II) bis(perchlorate) hemihydrate. IUCrData 2016, 1, x161009. [CrossRef]

68. Constable, E.C.; Harris, K.; Housecroft, C.E.; Neuburger, M.; Zampese, J.A. Turning $\left\{\mathrm{M}(\mathrm{tpy})_{2}\right\}^{n+}$ embraces and $\mathrm{CH} \cdots \pi$ interactions on and off in homoleptic cobalt(II) and cobalt(III) bis( $\left(2,2^{\prime}: 6^{\prime}, 2^{\prime \prime}\right.$-terpyridine $)$ complexes. CrystEngComm 2010, 12, 2949-2961. [CrossRef]

69. Oshio, H.; Spiering, H.; Ksenofontov, V.; Renz, F.; Gütlich, P. Electronic relaxation phenomena following ${ }^{57} \mathrm{Co}(\mathrm{EC}){ }^{57} \mathrm{Fe}$ nuclear decay in $\left[\mathrm{Mn}(\mathrm{III})(\text { terpy })_{2}\right]\left(\mathrm{ClO}_{4}\right)_{2} \cdot 1 / 2 \mathrm{H}_{2} \mathrm{O}$ and in the spin crossover complexes $\left[\mathrm{Co}(\mathrm{II})(\text { terpy })_{2}\right] \mathrm{X}_{2} \cdot n \mathrm{H}_{2} \mathrm{O}\left(\mathrm{X}=\mathrm{Cl}\right.$ and $\left.\mathrm{ClO}_{4}\right)$ : A Mössbauer emission spectroscopic study. Inorg. Chem. 2001, 40, 1143-1150. [CrossRef] [PubMed]

70. Romain, S.; Duboc, C.; Neese, F.; Rivière, E.; Hanton, L.R.; Blackman, A.G.; Philouze, C.; Leprêtre, J.-C.; Deronzier, A.; Collomb, M. An Unusual Stable Mononuclear Mn ${ }^{\text {III }}$ Bis-terpyridine Complex Exhibiting Jahn-Teller Compression: Electrochemical Synthesis, Physical Characterisation and Theoretical Study. Chem. Eur. J. 2009, 15, 980-988. [CrossRef] [PubMed]

71. Constable, E.C.; Housecroft, C.E.; Neuburger, M.; Schönle, J.; Zampese, J.A. The surprising lability of bis $\left(2,2^{\prime}: 6^{\prime}, 2^{\prime \prime}\right.$-terpyridine)chromium(III) complexes. Dalton Trans. 2014, 43, 7227-7235. [CrossRef] [PubMed]

72. Scudder, M.L.; Goodwin, H.A.; Dance, I.G. Crystal supramolecular motifs: Two-dimensional grids of terpy embraces in $\left[\mathrm{ML}_{2}\right]^{\mathrm{Z}}$ complexes ( $\mathrm{L}=$ terpy or aromatic $\mathrm{N}_{3}$-tridentate ligand). New J. Chem. 1999, 23, 695-705. [CrossRef]

73. Zhang, J.; Yan, X. Homoleptic Zinc(II) Complexes Based on 4'-(2-Thienyl)-terpyridine: Preparation, Structures, and Properties. Z. Anorg. Allg. Chem. 2017, 643, 398-402. [CrossRef]

74. Bozic-Weber, B.; Constable, E.C.; Hostettler, N.; Housecroft, C.E.; Schmitt, R.; Schönhofer, E. The d ${ }^{10}$ route to dye-sensitized solar cells: Step-wise assembly of zinc(II) photosensitizers on $\mathrm{TiO}_{2}$ surfaces. Chem. Commun. 2012, 48, 5727-5729. [CrossRef] [PubMed]

75. Jameson, D.L.; Guise, L.E. An improved, two-step synthesis of $2,2^{\prime}: 6^{\prime}, 2^{\prime \prime}$-terpyridine. Tetrahedron Lett. 1991, 32, 1999-2002. [CrossRef]

76. Elsbernd, H.; Beattie, J.K. The NMR spectra of terpyridine and the bis-terpyridine complexes of cobalt(III) and iron(II). J. Inorg. Nucl. Chem. 1972, 34, 771-774. [CrossRef]

77. Machan, C.W.; Adelhardt, M.; Sarjeant, A.A.; Stern, C.L.; Sutter, J.; Meyer, K.; Mirkin, C.A. One-Pot Synthesis of an Fe(II) Bis-Terpyridine Complex with Allosterically Regulated Electronic Properties. J. Am. Chem. Soc. 2012, 134, 16921-16924. [CrossRef] [PubMed]

78. Prasad, R.; Scaife, D.B. Electro-oxidation and electro-reduction of some iron(II), cobalt(II) and nickel(II) polypyridyl complexes in acetonitrile. J. Electroanal. Chem. 1977, 84, 373-386. [CrossRef]

79. Rao, J.M.; Hughes, M.C.; Macero, D.J. Voltammetry of terpyridine and terosine complexes of cobalt(II) and iron(II). Inorg. Chim. Acta 1976, 16, 231-236. [CrossRef]

80. Dobson, J.C.; Taube, H. Coordination chemistry and redox properties of polypyridyl complexes of vanadium(II). Inorg. Chem. 1989, 28, 1310-1315. [CrossRef]

81. Albano, G.; Balzani, V.; Constable, E.C.; Maestri, M.; Smith, D.R. Photoinduced processes in 4'-(9-anthryl)-2,2': $6^{\prime}, 2^{\prime \prime}$-terpyridine, its protonated forms and $\mathrm{Zn}(\mathrm{II}), \mathrm{Ru}(\mathrm{II})$ and $\mathrm{Os}(\mathrm{II})$ complexes. Inorg. Chim. Acta 1998, 277, 225-231. [CrossRef] 
82. Morgan, G.; Burstall, F.H. Researches on residual affinity and co-ordination. Part XXXVII. Complex metallic salts containing 2:6-di-2'-pyridylpyridine (2:2':2'”-tripyridyl). J. Chem. Soc. 1937, 1649-1655. [CrossRef]

83. Kahn, O. Molecular Magnetism; Wiley-VCH: New York, NY, USA, 1993; pp. 9-10.

84. Saravani, H.; Rezvani, A.R.; Hadadzadeh, H.; Safari, N. An Investigation of Z-in Distortion in Mononuclear $\mathrm{Cu}(\mathrm{II})$ Complex with Terpyridine Ligands, [Cu(terpy)2](PF6)2. Iran. J. Chem. Chem. Eng. 2007, 26, 103-110.

85. Folgado, J.-V.; Henke, W.; Allmann, R.; Stratemeier, H.; Beltrán-Porter, D.; Roja, T.; Reinen, D. Fluxionality in hexacoordinated copper(II) complexes with $2,2^{\prime}: 6^{\prime}, 2^{\prime \prime}$-terpyridine (terpy) and related ligands: Structural and spectroscopic investigations. Inorg. Chem. 1990, 29, 2035-2042. [CrossRef]

86. Hogg, R.; Wilkins, R.G. Exchange studies of certain chelate compounds of the transitional metals. Part VIII. $2,2^{\prime}, 2^{\prime \prime}$-terpyridine complexes. J. Chem. Soc. 1962, 341-350. [CrossRef]

87. Rao, J.M.; Hughes, M.C.; Macero, D.J. Redox behavior of aromatic tridentate imine ligand complexes of manganese and chromium. Inorg. Chim. Acta 1976, 18, 127-131. [CrossRef]

88. Scarborough, C.C.; Sproules, S.; Weyhermüller, T.; DeBeer, S.; Wieghardt, K. Electronic and Molecular Structures of the Members of the Electron Transfer Series $\left[\mathrm{Cr}\left({ }^{t} \mathrm{bpy}\right)_{3}\right]^{n}(n=3+, 2+, 1+, 0)$ : An X-ray Absorption Spectroscopic and Density Functional Theoretical Study. Inorg. Chem. 2011, 50, 12446-12462. [CrossRef] [PubMed]

89. Casellato, U.; Graziani, R.; Bonomo, R.P.; Di Bilio, A.J. X-ray crystal structures and electron spin resonance spectroscopic characterization of mixed-ligand chromium(III) complexes with L-aspartate or pyridine-2,6-dicarboxylate and 1,10-phenanthroline or 2,2':6',2" -terpyridyl. J. Chem. Soc. Dalton Trans. 1991, 23-31. [CrossRef]

90. Herzog, S.; Aul, H. Über elektronenreiche Komplexe des Vanadins mit 2,2' ,2" -Tripyridyl. Zeitschr. Chem. 1966, 6, 343-344. [CrossRef]

91. Henke, W.; Reinen, D. Spektroskopische Untersuchungen zum Jahn-Teller-Effekt des $\mathrm{Cu}^{2+}$-Ions in Terpyridin-Komplexen $\mathrm{Cu}$ (terpy) ${ }_{2} \mathrm{X}_{2} \mathrm{nH}_{2} \mathrm{O}\left[\mathrm{X}=\mathrm{NO}_{3}{ }^{-}, \mathrm{ClO}_{4}^{-}, \mathrm{Br}^{-}\right]$. Z. Anorg. Allg. Chem. 1977, 436, 187-200. [CrossRef]

92. Waldmann, O.; Hassmann, J.; Müller, P.; Volkmer, D.; Schubert, U.S.; Lehn, J.-M. Magnetism of self-assembled mono- and tetranuclear supramolecular $\mathrm{Ni}^{2+}$ complexes. Phys. Rev. B 1998, 58, 3277-3285. [CrossRef]

93. González, E.; Rodrigue-Witchel, A.; Reber, C. Absorption spectroscopy of octahedral nickel(II) complexes: A case study of interactions between multiple electronic excited states. Coord. Chem. Rev. 2007, 251, 351-363. [CrossRef]

94. Kuehnel, M.F.; Orchard, K.L.; Dalle, K.E.; Reisner, E. Selective Photocatalytic $\mathrm{CO}_{2}$ Reduction in Water through Anchoring of a Molecular Ni Catalyst on CdS Nanocrystals. J. Am. Chem. Soc. 2017, 139, 7217-7223. [CrossRef] [PubMed]

95. Judge, J.S.; Baker, W.A., Jr. On the spin equilibrium in bis $\left(2,2^{\prime}, 2^{\prime \prime}\right.$-terpyridine $)$ cobalt(II) salts. Inorg. Chim. Acta 1967, 1, 68-72. [CrossRef]

96. Kremer, S.; Henke, W.; Reinen, D. High-spin-low-spin equilibria of cobalt(2+) in the terpyridine complexes $\mathrm{Co}$ (terpy) ${ }_{2} \mathrm{X}_{2} \cdot n \mathrm{H}_{2} \mathrm{O}$. Inorg. Chem. 1982, 21, 3013-3022. [CrossRef]

97. Komatsu, Y.; Kato, K.; Yamamoto, Y.; Kamihata, H.; Lee, Y.H.; Fuyuhiro, A.; Kawata, S.; Hayami, S. Spin-Crossover Behaviors Based on Intermolecular Interactions for Cobalt(II) Complexes with Long Alkyl Chains. Eur. J. Inorg. Chem. 2012, 2769-2775. [CrossRef]

98. Hayami, S.; Shigeyoshi, Y.; Akita, M.; Inoue, K.; Kato, K.; Osaka, K.; Takata, M.; Kawajiri, R.; Mitani, T.; Maeda, Y. Reverse Spin Transition Triggered by a Structural Phase Transition. Angew. Chem. Int. Ed. 2005, 44, 4899-4903. [CrossRef] [PubMed]

99. Kilner, C.A.; Halcrow, M.A. An unusual discontinuity in the thermal spin transition in $\left[\mathrm{Co}(\operatorname{terpy})_{2}\right]\left[\mathrm{BF}_{4}\right]_{2}$. Dalton Trans. 2010, 39, 9008-9012. [CrossRef] [PubMed]

100. Chow, H.S.; Constable, E.C.; Housecroft, C.E.; Kulicke, K.J.; Tao, Y. When electron exchange is chemical exchange-assignment of ${ }^{1} \mathrm{H}$ NMR spectra of paramagnetic cobalt(II)-2,2' $: 6^{\prime}, 2^{\prime \prime}$-terpyridine complexes. Dalton Trans. 2005, 236-237. [CrossRef] [PubMed]

101. Beattie, J.K.; Binstead, R.A.; Kelso, M.T.; Del Favero, P.; Dewey, T.G.; Turner, D.H. Dynamics of cobalt(II) spin-equilibrium complexes. Inorg. Chim. Acta 1995, 235, 245-251. [CrossRef]

102. Mengel, A.K.C.; Cho, W.; Breivogel, A.; Char, K.; Kang, Y.S.; Heinze, K. A Bis(tridentate)cobalt Polypyridine Complex as Mediator in Dye-Sensitized Solar Cells. Eur. J. Inorg. Chem. 2015, 3299-3306. [CrossRef] 
103. Kreitner, C.; Mengel, A.K.C.; Lee, T.K.; Cho, W.; Char, K.; Kang, Y.S.; Heinze, K. Strongly Coupled Cyclometalated Ruthenium Triarylamine Chromophores as Sensitizers for DSSCs. Chem. Eur. J. 2016, 22, 8915-8928. [CrossRef] [PubMed]

104. Wentworth, R.A.D.; Piper, T.S. A Crystal Field Model for the Spectral Relationships in Monoacidopentaammine and Diacidotetraammine Complexes of Cobalt(III). Inorg. Chem. 1965, 4, 709-714. [CrossRef]

105. Sharma, R.P.; Singh, A.; Brandão, P.; Felix, V.; Venugopalan, P. Second sphere coordination in binding of fluoroanions: Synthesis, spectroscopic characterization and single crystal X-ray structure determination of $\left[\mathrm{Co}(\text { phen })_{3}\right]\left(\mathrm{BF}_{4}\right)_{3} \cdot \mathrm{H}_{2} \mathrm{O}$ and $\left[\mathrm{Co}(\text { phen })_{3}\right]\left(\mathrm{PF}_{6}\right)_{3} \cdot \mathrm{CH}_{3} \mathrm{COCH}_{3}$. J. Mol. Struct. 2009, 920, 119-127. [CrossRef]

106. Sutin, N.; Brunschwig, B.S.; Creutz, C.; Winkler, J.R. Nuclear reorganization barriers to electron transfer. Pure Appl. Chem. 1988, 60, 1817-1830. [CrossRef]

107. Cummins, D.; Gray, H.B. Electron-transfer protein reactivities. Kinetic studies of the oxidation of horse heart cytochrome c, Chromatium vinosum high potential iron-sulfur protein, Pseudomonas aeruginosa azurin, bean plastocyanin, and Rhus vernicifera stellacyanin by pentaammminepyridineruthenium(III). J. Am. Chem. Soc. 1977, 99, 5158-5167. [CrossRef] [PubMed]

108. Chou, M.; Creutz, C.; Sutin, N. Rate constants and activation parameters for outer-sphere electron-transfer reactions and comparisons with the predictions of Marcus theory. J. Am. Chem. Soc. 1977, 99, 5615-5623. [CrossRef]

109. Ondersma, J.W.; Hamann, T.W. Recombination and redox couples in dye-sensitized solar cells. Coord. Chem. Rev. 2103, 257, 1533-1543. [CrossRef]

110. Yum, J.-H.; Baranoff, E.; Kessler, F.; Moehl, T.; Ahmad, S.; Bessho, T.; Marchioro, A.; Ghadiri, E.; Moser, J.-E.; Yi, C.; et al. A cobalt complex redox shuttle for dye-sensitized solar cells with high open-circuit potentials. Nat. Commun. 2012, 3, 631. [CrossRef] [PubMed]

111. Harzmann, G.D.; Neuburger, M.; Mayor, M. 4,4"-Disubstituted Terpyridines and Their Homoleptic Fe $\mathrm{F}^{\mathrm{II}}$ Complexes. Eur. J. Inorg. Chem. 2013, 3334-3347. [CrossRef]

112. Pazderski, L.; Pawlak, T.; Sitkowski, J.; Kozerski, L.; Szlyk, E. ${ }^{1} \mathrm{H},{ }^{13} \mathrm{C},{ }^{15} \mathrm{~N}$ NMR coordination shifts in Fe(II), $\mathrm{Ru}(\mathrm{II})$ and $\mathrm{Os}(\mathrm{II})$ cationic complexes with 2,2':6',2'-terpyridine. Magn. Reson. Chem. 2011, 49, $237-241$. [CrossRef] [PubMed]

113. Mack, K. Neue Übergangsmetall-Komplexe des $N, N^{\prime}$-dimethyl- $N, N^{\prime}$-dipyridin-2-ylpyridin-2,6-diaminsStrukturelle, magnetische und optische Eigenschaften. Diploma Thesis, Johannes Gutenberg University, Mainz, Germany, 2012.

114. Shepard, S.G.; Fatur, S.M.; Rappé, A.K.; Damrauer, N.H. Highly Strained Iron(II) Polypyridines: Exploiting the Quintet Manifold To Extend the Lifetime of MLCT Excited States. J. Am. Chem. Soc. 2016, 138, 2949-2952. [CrossRef] [PubMed]

115. Fatur, S.M.; Shepard, S.G.; Higgins, R.F.; Shores, M.P.; Damrauer, N.H. A Synthetically Tunable System To Control MLCT Excited-State Lifetimes and Spin States in Iron(II) Polypyridines. J. Am. Chem. Soc. 2017, 139, 4493-4505. [CrossRef] [PubMed]

116. Yang, M.; Lin, T.-W.; Chou, C.-C.; Lee, H.-C.; Chang, H.-C.; Lee, G.-H.; Leung, M.; Peng, S.-P. New oligo- $\alpha$-pyridylamino ligands and their metal complexes. Chem. Commun. 1997, 2279-2280. [CrossRef]

117. Jamula, L.L.; Brown, A.M.; Guo, D.; McCusker, J.K. Synthesis and Characterization of a High-Symmetry Ferrous Polypyridyl Complex: Approaching the ${ }^{5} \mathrm{~T}_{2} /{ }^{3} \mathrm{~T}_{1}$ Crossing Point for Fe ${ }^{\mathrm{II}}$. Inorg. Chem. 2014, 53, 15-17. [CrossRef] [PubMed]

118. Liu, Y.; Harlang, T.; Canton, S.E.; Chábera, P.; Suárez-Alcántara, K.; Fleckhaus, A.; Vithanage, D.A.; Göransson, E.; Corani, A.; Lomoth, R.; et al. Towards longer-lived metal-to-ligand charge transfer states of iron(II) complexes: An N-heterocyclic carbene approach. Chem. Commun. 2013, 49, 6412-6414. [CrossRef] [PubMed]

119. Liu, Y.; Kjær, K.S.; Fredin, L.A.; Chábera, P.; Harlang, T.; Canton, S.E.; Lidin, S.; Zhang, J.; Lomoth, R.; Bergquist, K.-E.; et al. A Heteroleptic Ferrous Complex with Mesoionic Bis(1,2,3-triazol-5-ylidene) Ligands: Taming the MLCT Excited State of Iron(II). Chem. Eur. J. 2015, 21, 3628-3639. [CrossRef] [PubMed]

120. Liu, L.; Duchanois, T.; Etienne, T.; Monari, A.; Beley, M.; Assfeld, X.; Haacke, S.; Gros, P.C. A new record excited state ${ }^{3}$ MLCT lifetime for metalorganic iron(II) complexes. Phys. Chem. Chem. Phys. 2016, 18, 12550-12556. [CrossRef] [PubMed] 
121. Zimmer, P.; Burkhardt, L.; Friedrich, A.; Steube, J.; Neuba, A.; Schepper, R.; Müller, P.; Flörke, U.; Huber, M.; Lochbrunner, S.; et al. The Connection between NHC Ligand Count and Photophysical Properties in Fe(II) Photosensitizers: An Experimental Study. Inorg. Chem. 2018, 57, 360-373. [CrossRef] [PubMed]

122. Chábera, P.; Kjaer, K.S.; Prakash, O.; Honarfar, A.; Liu, Y.; Fredin, L.A.; Harlang, T.C.B.; Lidin, S.; Uhlig, J.; Sundström, V.; et al. Fe ${ }^{\mathrm{II}}$ Hexa N-Heterocyclic Carbene Complex with a 528 ps Metal-to-Ligand Charge-Transfer Excited-State Lifetime. J. Phys. Chem. Lett. 2018, 9, 459-463. [CrossRef] [PubMed]

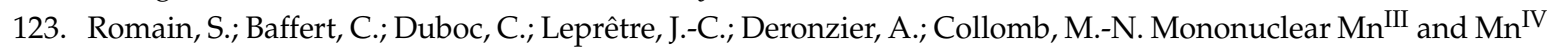
Bis-terpyridine Complexes: Electrochemical Formation and Spectroscopic Characterizations. Inorg. Chem. 2009, 48, 3125-3131. [CrossRef] [PubMed]

124. Limburg, J.; Vrettos, J.S.; Liable-Sands, L.M.; Rheingold, A.L.; Crabtree, R.H.; Brudvig, G.W. A Functional Model for O-O Bond Formation by the $\mathrm{O}_{2}$-Evolving Complex in Photosystem II. Science 1999, 283, $1524-1527$. [CrossRef] [PubMed]

125. Young, K.J.; Brennan, B.J.; Tagore, R.; Brudvig, G.W. Photosynthetic Water Oxidation: Insights from Manganese Model Chemistry. Acc. Chem. Res. 2015, 48, 567-574. [CrossRef] [PubMed]

126. Zare, D.; Doistau, B.; Nozary, H.; Besnard, C.; Guénée, L.; Suffren, Y.; Pelé, A.-L.; Hauser, A.; Piguet, C. Cr ${ }^{\mathrm{III}}$ as an alternative to $\mathrm{Ru}^{\mathrm{II}}$ in metallo-supramolecular chemistry. Dalton Trans. 2017, 46, 8992-9009. [CrossRef] [PubMed]

127. Cloete, N.; Visser, H.G.; Roodt, A. mer-Trichloro(2,2',2"'-terpyridine)chromium(III) dimethyl sulfoxide solvate. Acta Crystallogr. Sect. E Struct. Rep. Online 2007, 63, m45-m47. [CrossRef]

128. Henriques, R.T.; Herdtweck, E.; Kühn, F.E.; Lopes, A.D.; Mink, J.; Romão, C.C. Synthesis, characterization, and reactions of tetrakis(nitrile)chromium(II) tetrafluoroborate complexes. J. Chem. Soc. Dalton Trans. 1998, 1293-1297. [CrossRef]

129. Åkesson, R.; Pettersson, L.G.M.; Sandström, M.; Wahlgren, U. Theoretical calculations of the Jahn-Teller effect in the hexahydrated Copper(II), chromium(II), and manganese(III) ions, hexaaquacopper(2+), hexaaquachromium(2+) and hexaaquamanganese (3+), and comparisons with the hexahydrated copper(I), chromium(III), and manganese(II) clusters. J. Phys. Chem. 1992, 96, 150-156. [CrossRef]

130. Thangavel, A.; Wieliczko, M.; Scarborough, C.; Dittrich, B.; Bacsa, J. An investigation of the electron density of a Jahn-Teller-distorted $\mathrm{Cr}^{\mathrm{II}}$ cation: The crystal structure and charge density of hexakis(acetonitrileKN)chromium(II) bis(tetraphenylborate) acetonitrile disolvate. Acta Crystallogr. Sect. C 2015, C71, 936-943. [CrossRef] [PubMed]

131. Hieber, W.; Mühlbauer, F. Über Metallcarbonyle. XII. Reaktionen und Derivate der Hexacarbonyle des Chroms und Molybdäns. Z. Anorg. Allg. Chem. 1935, 221, 337-348. [CrossRef]

132. Hieber, W.; Abeck, W.; Platzer, H.K. Über Metallcarbonyle. 69. Über Tricarbonyl-triammin-Chrom und seine Derivate. Z. Anorg. Allg. Chem. 1955, 280, 252-263. [CrossRef]

133. Kuo, C.-Y.; Fuh, Y.-S.; Shiue, J.-Y.; Yu, S.J.; Lee, G.-H.; Peng, S.-M. Syntheses and chemistry of Tris(2-pyridyl) phosphine complexes of Group VI transition metals. X-ray structural studies of the molybdenum complexes. J. Organomet. Chem. 1999, 588, 260-267. [CrossRef]

134. Howie, R.A.; McQuillan, G.P. Trisubstituted Group 6 metal carbonyl complexes with di-2-pyridylamine ligands. Crystal structures of $\left(2,2^{\prime}\right.$-bipyridyl- $\left.N, N^{\prime}\right)$ tricarbonyl(di-2-pyridylamine- $\left.N^{\prime}\right)$-molybdenum $(0)$ and -tungsten(0). J. Chem. Soc. Dalton Trans. 1986, 759-764. [CrossRef]

135. Otto, S. Synthese, experimentelle und theoretische Charakterisierung neuartiger Polypyridyl-Komplexe des Chrom, Mangan und Zink. Diploma Thesis, Johannes Gutenberg University, Mainz, Germany, 2015.

136. Xiang, H.; Cheng, J.; Ma, X.; Zhou, X.; Chruma, J.J. Near-infrared phosphorescence: Materials and applications. Chem. Soc. Rev. 2013, 42, 6128-6185. [CrossRef] [PubMed]

137. Barbour, J.C.; Kim, A.J.I.; de Vries, E.; Shaner, S.E.; Lovaasen, B.M. Chromium (III) Bis-Arylterpyridyl Complexes with Enhanced Visible Absorption via Incorporation of Intraligand Charge-Transfer Transitions. Inorg. Chem. 2017, 56, 8212-8222. [CrossRef] [PubMed]

138. Otto, S.; Förster, C.; Wang, C.; Resch-Genger, U.; Heinze, K. A strongly luminescent chromium(III) complex acid. Chem. Eur. J. 2018, 24. in press. [CrossRef]

139. Otto, S.; Nauth, A.M.; Ermilov, E.; Scholz, N.; Friedrich, A.; Resch-Genger, U.; Lochbrunner, S.; Opatz, T.; Heinze, K. Photo-Chromium: Sensitizer for Visible-Light-Induced Oxidative C-H Bond Functionalization-Electron or Energy Transfer? ChemPhotoChem 2017, 1, 344-349. [CrossRef] 
140. Vaidyanathan, V.G.; Nair, B.U. Nucleobase Oxidation of DNA by (Terpyridyl)chromium(III) Derivatives. Eur. J. Inorg. Chem. 2004, 1840-1846. [CrossRef]

141. Stevenson, S.M.; Shores, M.P.; Ferreira, E.M. Photooxidizing Chromium Catalysts for Promoting Radical Cation Cycloadditions. Angew. Chem. Int. Ed. 2015, 54, 6506-6510. [CrossRef] [PubMed]

142. Higgins, R.F.; Fatur, S.M.; Shepard, S.G.; Stevenson, S.M.; Boston, D.J.; Ferreira, E.M.; Damrauer, N.H.; Rappé, A.K.; Shores, M.P. Uncovering the Roles of Oxygen in $\mathrm{Cr}(\mathrm{III})$ Photoredox Catalysis. J. Am. Chem. Soc. 2016, 138, 5451-5464. [CrossRef] [PubMed]

143. Stevenson, S.M.; Higgins, R.F.; Shores, M.P.; Ferreira, E.M. Chromium photocatalysis: Accessing structural complements to Diels-Alder adducts with electron-deficient dienophiles. Chem. Sci. 2017, 8, 654-660. [CrossRef] [PubMed]

144. Otto, S.; Scholz, N.; Behnke, T.; Resch-Genger, U.; Heinze, K. Thermo-Chromium: A Contactless Optical Molecular Thermometer. Chem. Eur. J. 2017, 23, 12131-12135. [CrossRef] [PubMed]

145. Otto, S.; Harris, J.P.; Heinze, K.; Reber, C. Molecular Ruby under Pressure. Angew. Chem. Int. Ed. 2018, 57, 11069-11073. [CrossRef] [PubMed]

146. Forman, R.A.; Piermarini, G.J.; Barnett, J.D.; Block, S. Pressure measurement made by the utilization of ruby sharp-line luminescence. Science 1972, 176, 284-285. [CrossRef] [PubMed]

147. Pajdowski, L.; Karwecka, Z.; Fried, K.; Adamczak, H. Complex compounds of vanadium(III) in pyridine solutions. J. Inorg. Nucl. Chem. 1974, 36, 585-589. [CrossRef]

148. Casey, A.T.; Clark, R.J.H. Preparations and properties of vanadium(III) complexes of bidentate and terdentate nitrogen-donor ligands. Transit. Met. Chem. 1977, 2, 76-80. [CrossRef]

149. Silverman, L.D.; Dewan, J.C.; Giandomenico, C.M.; Lippard, S.J. Molecular structure and ligand-exchange reactions of trichlorotris(tert-butyl isocyanide)vanadium(III). Synthesis of the hexakis(tert-butyl isocyanide)vanadium(II) cation. Inorg. Chem. 1980, 19, 3379-3383. [CrossRef]

150. Manzer, L.E.; Deaton, J.; Sharp, P.; Schrock, R.R. Tetrahydrofuran Complexes of Selected Early Transition Metals. Inorg. Synth. 1982, 21, 135-140. [CrossRef]

151. Abbo, H.S.; Titinchi, S.J.J. A New Vanadium (III) Complex of 2,6-Bis(3,5-diphenylpyrazol-1-ylmethyl)pyridine as a Catalyst for Ethylene Polymerization. Molecules 2013, 18, 4728-4738. [CrossRef] [PubMed]

152. Perry, M.R.; Allan, L.E.N.; Decken, A.; Shaver, M.P. Organometallic mediated radical polymerization of vinyl acetate using bis(imino)pyridine vanadium trichloride complexes. Dalton Trans. 2013, 42, 9157-9165. [CrossRef] [PubMed]

153. Bennett, L.E.; Taube, H. An Investigation of the Vanadium(II)-Vanadium(III) Couple with Polypyridine Ligands. Inorg. Chem. 1968, 7, 254-261. [CrossRef]

154. Behrens, H.; Brandl, H.; Lutz, K. Über Bis-[tripyridyl(2.2'.2' $)$ ]-vanadin(0). Z. Naturforsch. 1967, $22 b, 99-100$. [CrossRef]

155. Wang, M.; Weyhermüller, T.; England, J.; Wieghardt, K. Molecular and Electronic Structures of Six-Coordinate "Low-Valent" $\left[\mathrm{M}\left({ }^{\mathrm{Me}} \mathrm{bpy}\right)_{3}\right]^{0}(\mathrm{M}=\mathrm{Ti}, \mathrm{V}, \mathrm{Cr}, \mathrm{Mo})$ and $\left[\mathrm{M}(\mathrm{tpy})_{2}\right]^{0}(\mathrm{M}=\mathrm{Ti}, \mathrm{V}, \mathrm{Cr})$, and Seven-Coordinate $\left[\mathrm{MoF}\left({ }^{\mathrm{Me}} \mathrm{bpy}\right)_{3}\right]\left(\mathrm{PF}_{6}\right)$ and $\left[\mathrm{MX}\left(\mathrm{tpy}_{2}\right)_{2}\right]\left(\mathrm{PF}_{6}\right)(\mathrm{M}=\mathrm{Mo}, \mathrm{X}=\mathrm{Cl}$ and $\mathrm{M}=\mathrm{W}, \mathrm{X}=\mathrm{F})$. Inorg. Chem. 2013, 52, 12763-12776. [CrossRef] [PubMed]

156. STOE \& Cie. X-Red; STOE \& Cie: Darmstadt, Germany, 2002.

157. Blessing, R.H. An empirical correction for absorption anisotropy. Acta Crystallogr. A 1995, 51, 33-38. [CrossRef] [PubMed]

158. Spek, A.L. Structure validation in chemical crystallography. Acta Crystallogr. D 2009, 65, 148-155. [CrossRef] [PubMed]

159. Sheldrick, G.M. SHELXT-Integrated space-group and crystal structure determination. Acta Crystallogr. A 2015, 71, 3-8. [CrossRef] [PubMed]

160. Sheldrick, G.M. SHELXL-2014/7; University of Göttingen: Göttingen, Germany, 2014.

161. Fulmer, G.R.; Miller, A.J.M.; Sherden, N.H.; Gottlieb, H.E.; Nudelman, A.; Stoltz, B.M.; Bercaw, J.E.; Goldberg, K.I. NMR Chemical Shifts of Trace Impurities: Common Laboratory Solvents, Organics, and Gases in Deuterated Solvents Relevant to the Organometallic Chemist. Organometallics 2010, 29, 2176-2179. [CrossRef]

162. Neese, F. The ORCA program system. WIREs Comput. Mol. Sci. 2012, 2, 73-78. [CrossRef] 
163. Becke, A.D. Density-functional thermochemistry. III. The role of exact exchange. J. Chem. Phys. 1993, 98, 5648-5652. [CrossRef]

164. Lee, C.; Yang, W.; Parr, R.G. Development of the Colic-Salvetti correlation-energy formula into a functional of the electron density. Phys. Rev. B 1988, 37, 785-789. [CrossRef]

165. Miehlich, B.; Savin, A.; Stoll, H.; Preuss, H. Results obtained with the correlation energy density functionals of becke and Lee, Yang and Parr. Chem. Phys. Lett. 1989, 157, 200-206. [CrossRef]

166. Neese, F.; Wennmohs, F.; Hansen, A.; Becker, U. Efficient, approximate and parallel Hartree-Fock and hybrid DFT calculations. A 'chain-of-spheres' algorithm for the Hartree-Fock exchange. Chem. Phys. 2009, 356, 98-109. [CrossRef]

167. Izsák, R.; Neese, F. An overlap fitted chain of spheres exchange method. J. Chem. Phys. 2011, 135, 144105. [CrossRef] [PubMed]

168. Pantazis, D.A.; Chen, X.-Y.; Landis, C.R.; Neese, F. All-Electron Scalar Relativistic Basis Sets for Third-Row Transition Metal Atoms. J. Chem. Theory Comput. 2008, 4, 908-919. [CrossRef] [PubMed]

169. Sinnecker, S.; Rajendran, A.; Klamt, A.; Diedenhofen, M.; Neese, F. Calculation of Solvent Shifts on Electronic g-Tensors with the Conductor-Like Screening Model (COSMO) and Its Self-Consistent Generalization to Real Solvents (Direct COSMO-RS). J. Phys. Chem. A 2006, 110, 2235-2245. [CrossRef] [PubMed]

170. Weigend, F.; Ahlrichs, R. Balanced basis sets of split valence, triple zeta valence and quadruple zeta valence quality for $\mathrm{H}$ to Rn: Design and assessment of accuracy. Phys. Chem. Chem. Phys. 2005, 7, 3297-3305. [CrossRef] [PubMed]

171. Weigend, F. Accurate Coulomb-fitting basis sets for H to Rn. Phys. Chem. Chem. Phys. 2006, 8, 1057-1065. [CrossRef] [PubMed]

172. Grimme, S.; Antony, J.; Ehrlich, S.; Krieg, H. A consistent and accurate ab initio parametrization of density functional dispersion correction (DFT-D) for the 94 elements H-Pu. J. Chem. Phys. 2010, 132, 154104. [CrossRef] [PubMed]

173. Grimme, S.; Ehrlich, S.; Goerigk, L. Effect of the damping function in dispersion corrected density functional theory. J. Comput. Chem. 2011, 32, 1456-1465. [CrossRef] [PubMed]

174. Evans, D.F. The Determination of the Paramagnetic Susceptibility of Substances in Solution by Nuclear Magnetic Resonance. J. Chem. Soc. 1959, 2003-2005. [CrossRef]

175. Evans, D.F.; Fazakerley, G.V.; Phillips, R.F. Organometallic Compounds of Bivalent Europium, Ytterbium, and Samarium. J. Chem. Soc. A 1971, 1931-1934. [CrossRef] 